\title{
Acid gases and aerosol measurements in the UK (1999-2015): regional distributions and trends
}

\author{
Y. Sim Tang ${ }^{1}$, Christine F. Braban ${ }^{1}$, Ulrike Dragosits ${ }^{1}$, Ivan Simmons ${ }^{1}$, David Leaver ${ }^{1}$, Netty van Dijk ${ }^{1}$, \\ Janet Poskitt ${ }^{2}$, Sarah Thacker ${ }^{2}$, Manisha Patel ${ }^{2}$, Heather Carter ${ }^{2}$, M. Glória Pereira ${ }^{2}$, Patrick O. Keenan ${ }^{2}$, \\ Alan Lawlor ${ }^{2}$, Christopher Conolly ${ }^{3}$, Keith Vincent ${ }^{3}$, Mathew R. Heal ${ }^{4}$, and Mark A. Sutton ${ }^{1}$ \\ ${ }^{1}$ CEH, Bush Estate, Penicuik, Midlothian EH26 0QB, UK \\ ${ }^{2} \mathrm{CEH}$, Lancaster Environment Centre, Bailrigg, Lancaster LA1 4AP, UK \\ ${ }^{3}$ Ricardo Energy \& Environment, Gemini Building, Fermi Avenue, Harwell, Oxon, OX11 0QR, UK \\ ${ }^{4}$ School of Chemistry, University of Edinburgh, David Brewster Road, Edinburgh EH9 3FJ, UK
}

Correspondence: Y. Sim Tang (yst@ ceh.ac.uk)

Received: 15 May 2018 - Discussion started: 25 May 2018

Revised: 11 October 2018 - Accepted: 26 October 2018 - Published: 16 November 2018

\begin{abstract}
The UK Acid Gases and Aerosol Monitoring Network (AGANet) was established in 1999 (12 sites, increased to 30 sites from 2006), to provide long-term national monitoring of acid gases $\left(\mathrm{HNO}_{3}, \mathrm{SO}_{2}, \mathrm{HCl}\right)$ and aerosol components $\left(\mathrm{NO}_{3}^{-}, \mathrm{SO}_{4}^{2-}, \mathrm{Cl}^{-}, \mathrm{Na}^{+}, \mathrm{Ca}^{2+}, \mathrm{Mg}^{2+}\right)$. An extension of a low-cost denuder-filter pack system (DELTA) that is used to measure $\mathrm{NH}_{3}$ and $\mathrm{NH}_{4}^{+}$in the UK National Ammonia Monitoring Network (NAMN) provides additional monthly speciated measurements for the AGANet. A comparison of the monthly DELTA measurement with averaged daily results from an annular denuder system showed close agreement, while the sum of $\mathrm{HNO}_{3}$ and $\mathrm{NO}_{3}^{-}$and the sum of $\mathrm{NH}_{3}$ and $\mathrm{NH}_{4}^{+}$from the DELTA are also consistent with previous filter pack determination of total inorganic nitrogen and total inorganic ammonium, respectively. With the exception of $\mathrm{SO}_{2}$ and $\mathrm{SO}_{4}^{2-}$, the AGANet provides, for the first time, the UK concentration fields and seasonal cycles for each of the other measured species. The largest concentrations of $\mathrm{HNO}_{3}, \mathrm{SO}_{2}$, and aerosol $\mathrm{NO}_{3}^{-}$and $\mathrm{SO}_{4}^{2-}$ are found in southern and eastern England and smallest in western Scotland and Northern Ireland, whereas $\mathrm{HCl}$ are highest in southeastern, south-western, and central England, that may be attributed to dual contribution from anthropogenic (coal combustion) and marine sources (reaction of sea salt with acid gases to form $\mathrm{HCl}$ ). $\mathrm{Na}^{+}$and $\mathrm{Cl}^{-}$are spatially correlated, with largest concentrations at coastal sites, reflecting a contribution from sea salt. Temporally, peak concentrations in $\mathrm{HNO}_{3}$ occurred in late winter and early spring attributed to
\end{abstract}

photochemical processes. $\mathrm{NO}_{3}^{-}$and $\mathrm{SO}_{4}^{2-}$ have a spring maxima that coincides with the peak in concentrations of $\mathrm{NH}_{3}$ and $\mathrm{NH}_{4}^{+}$, and are therefore likely attributable to formation of $\mathrm{NH}_{4} \mathrm{NO}_{3}$ and $\left(\mathrm{NH}_{4}\right)_{2} \mathrm{SO}_{4}$ from reaction with higher concentrations of $\mathrm{NH}_{3}$ in spring. By contrast, peak concentrations of $\mathrm{SO}_{2}, \mathrm{Na}^{+}$, and $\mathrm{Cl}^{-}$during winter are consistent with combustion sources for $\mathrm{SO}_{2}$ and marine sources in winter for sea salt aerosol. Key pollutant events were captured by the AGANet. In 2003, a spring episode with elevated concentrations of $\mathrm{HNO}_{3}$ and $\mathrm{NO}_{3}^{-}$was driven by meteorology and transboundary transport of $\mathrm{NH}_{4} \mathrm{NO}_{3}$ from Europe. A second, but smaller episode occurred in September 2014, with elevated concentrations of $\mathrm{SO}_{2}, \mathrm{HNO}_{3}, \mathrm{SO}_{4}^{2-}, \mathrm{NO}_{3}^{-}$, and $\mathrm{NH}_{4}^{+}$ that was shown to be from the Icelandic Holuhraun volcanic eruptions. Since 1999, AGANet has shown substantial decrease in $\mathrm{SO}_{2}$ concentrations relative to $\mathrm{HNO}_{3}$ and $\mathrm{NH}_{3}$, consistent with estimated decline in UK emissions. At the same time, large reductions and changes in the aerosol components provide evidence of a shift in the particulate phase from $\left(\mathrm{NH}_{4}\right)_{2} \mathrm{SO}_{4}$ to $\mathrm{NH}_{4} \mathrm{NO}_{3}$. The potential for $\mathrm{NH}_{4} \mathrm{NO}_{3}$ to release $\mathrm{NH}_{3}$ and $\mathrm{HNO}_{3}$ in warm weather, together with the surfeit of $\mathrm{NH}_{3}$ also means that a larger fraction of the reduced and oxidized $\mathrm{N}$ is remaining in the gas phase as $\mathrm{NH}_{3}$ and $\mathrm{HNO}_{3}$ as indicated by the increasing trend in ratios of $\mathrm{NH}_{3}: \mathrm{NH}_{4}^{+}$and $\mathrm{HNO}_{3}: \mathrm{NO}_{3}^{-}$over the 16 -year period. Due to different removal rates of the component species by wet and dry deposition, this change is expected to affect spatial patterns of pollutant deposition with consequences for 
sensitive habitats with exceedance of critical loads of acidity and eutrophication. The changes are also relevant for human health effects assessment, particularly in urban areas as $\mathrm{NH}_{4} \mathrm{NO}_{3}$ constitutes a significant fraction of fine particulate matter $(<2.5 \mu \mathrm{m})$ that are linked to increased mortality from respiratory and cardiopulmonary diseases.

\section{Introduction}

Monitoring the atmospheric concentrations of acid gases and their aerosol reaction products is important for assessing their effects on human health, ecosystems, long-range transboundary transport and global radiative balance. Concentration data are necessary for quantifying long-term trends and spatial patterns, understanding gas-aerosol phase interactions, and estimating the contributions of different pollutants to dry deposition fluxes (ROTAP, 2012; AQEG, 2013a; Colette et al., 2016), as well as to provide data for testing the performance of atmospheric models (e.g. Chemel et al., 2010; Vieno et al., 2014, 2016). Acid gases in the atmosphere include sulfur dioxide $\left(\mathrm{SO}_{2}\right)$, nitrogen oxides $\left(\mathrm{NO}_{x}\right)$, nitric acid $\left(\mathrm{HNO}_{3}\right)$, hydrochloric acid $(\mathrm{HCl})$ and nitrous acid (HONO). Secondary inorganic aerosols (SIA) include sulfate $\left(\mathrm{SO}_{4}^{2-}\right)$, nitrate $\left(\mathrm{NO}_{3}^{-}\right)$, chloride $\left(\mathrm{Cl}^{-}\right)$and nitrite $\left(\mathrm{NO}_{2}^{-}\right)$that are formed from reactions of $\mathrm{SO}_{2}$ and $\mathrm{NO}_{x}$ (and $\mathrm{HNO}_{3}$, a secondary product of $\left.\mathrm{NO}_{x}\right)$ with ammonia $\left(\mathrm{NH}_{3}\right)$ in the atmosphere. These aerosols make an important contribution to concentrations of particulate matter (PM) in the UK (15\%$50 \%$ of the mass of atmospheric PM) and constitute a significant fraction of fine particles that are less than $2.5 \mu \mathrm{m}$ in diameter $\left(\mathrm{PM}_{2.5}\right)$ implicated in harming human health (AQEG, 2012, 2013b). In addition, base cations in aerosol are also of interest to estimate the extent to which acidity is neutralized and to estimate the contribution of marine influences (ROTAP, 2012; Werner et al., 2011).

Anthropogenic emissions of $\mathrm{SO}_{2}, \mathrm{NO}_{x}, \mathrm{HCl}$, and $\mathrm{NH}_{3}$ in the UK declined by $81 \%, 51 \%, 87 \%$, and $13 \%$, respectively, over the period 1999 to 2015 (NAEI, 2018). Despite the success in mitigating $\mathrm{SO}_{2}$ emissions however, sulfur still remains a pollutant of national importance, because reduction in sulfur deposition in remote sensitive areas have been more modest than close to major sources (ROTAP, 2012). $\mathrm{HCl}$ was also recently identified as another important acidifying pollutant for sensitive habitats (Evans et al., 2011). Emissions of $\mathrm{HCl}$ (from coal burning in power stations) have however declined to very low levels (from $74 \mathrm{kt}$ in 1999 to $9 \mathrm{kt}$ in 2015), although it could still pose a threat to habitats close to these sources. For $\mathrm{NO}_{x}$, the more modest decrease in emissions reflects difficulties in their abatement, while for $\mathrm{NH}_{3}$, the decrease to date is largely a result of changes in animal numbers (NAEI, 2018).

With the decline in $\mathrm{SO}_{2}$ emissions and deposition, the large number of reactive nitrogen compounds in the atmo- sphere are assuming greater importance owing to the complexities of the global $\mathrm{N}$ cycle and associated challenges in their abatement. These include the gas phase components $\mathrm{NH}_{3}$, with over $80 \%$ estimated from agricultural emissions (EEA, 2017) and nitrogen oxides $\left(\mathrm{NO}, \mathrm{NO}_{2}\right)$ from combustion, the secondary gas phase reaction products $\mathrm{HNO}_{3}$, HONO and PAN (peroxyacetyl nitrate), and particulate phase components $\left(\left(\mathrm{NH}_{4}\right)_{2} \mathrm{SO}_{4}, \mathrm{NH}_{4} \mathrm{HSO}_{4}\right.$, and $\left.\mathrm{NH}_{4} \mathrm{NO}_{3}\right)$ formed by the reaction between $\mathrm{NH}_{3}$ and acid gases (AQEG, 2012). Ammonia and the $\mathrm{N}$-containing aerosols are known to cause nitrogen enrichment and eutrophication, as well as contributing to acidification processes (Sutton et al., 2011). Oxidized nitrogen species $\left(\mathrm{NO}_{x}\right)$ are precursors to ground-level $\mathrm{O}_{3}$ formation, while the production of acids $\left(\mathrm{HNO}_{3}, \mathrm{HONO}\right)$ and PAN in the atmosphere affects air quality and is damaging both to human health and to vegetation (Cowling et al., 1998; Bobbink et al., 2010).

In Europe, air pollution policies regarding acidification and nitrogen eutrophication apply the "critical loads approach" (Bull, 1995; Gregor et al., 2001), which requires that atmospheric deposition inputs be mapped at an appropriate scale for the assessment of effects. In parallel, the "critical levels" of concentrations addresses the direct impacts of concentrations of nitrogen components in the atmosphere (Bull, 1991; Gregor et al., 2001; Cape et al., 2009). Quantifying the dry deposition of reactive nitrogen compounds is a major challenge and a key source of uncertainty for effects assessment (Dentener et al., 2006; Flechard et al., 2011; Schrader et al., 2018; Sutton et al., 2007). While deposition may be estimated using atmospheric transport and chemistry models (e.g. Dore et al., 2015; Flechard et al., 2011; Smith et al., 2000), air concentration data at sufficient spatial resolution are needed, both to assess the atmospheric models and provide input data for estimating deposition using inferential models.

In light of policies to reduce atmospheric emissions, e.g. the amended 2012 Gothenburg Protocol (UNECE, 2018) and the revised National Emissions Ceilings Directive (NECD, EU Directive 2016/2284) (EU, 2016), it is important to assess long-term trends in the measured pollutants, since this provides the only independent means to assess the effectiveness of any abatement policies. Both these international agreements set emissions reduction commitments for $\mathrm{SO}_{2}, \mathrm{NO}_{x}$ and $\mathrm{NH}_{3}$, of $59 \%, 42 \%$, and $6 \%$, respectively, by 2020 (with 2005 as base year) and includes $\mathbf{P M}_{2.5}$ for the very first time. Under the $2016 \mathrm{NECD}$, further reduction commitments of $79 \%\left(\mathrm{SO}_{2}\right), 63 \%\left(\mathrm{NO}_{x}\right)$, and $19 \%\left(\mathrm{NH}_{3}\right)$ are also set for the EU 28 countries from 2030. Since emissions of these gases come from different sources, emissions controls require very different strategies, making it important to monitor and assess the relative concentrations and deposition of nitrogen and sulfur components.

The spatial and temporal patterns of gases and particulate phases of these pollutants differ substantially. Although it is widely acknowledged that speciation between reactive gas 
and aerosol measurement is critical, there are few national long-term monitoring programmes dedicated to measuring their concentrations and dry depositions separately at high spatial resolution (Tørseth et al., 2012). Across Europe, the European Monitoring and Evaluation Programme (EMEP, 2014) continues to recommend using a daily filter pack sampling method to measure oxidized nitrogen (total inorganic nitrate, TIN) and reduced nitrogen (total inorganic ammonia, TIA) (Tørseth et al., 2012; Colette et al., 2016). The filter pack method is generally considered as robust for measuring $\mathrm{SO}_{2}$ and $\mathrm{SO}_{4}^{2-}$ concentrations (EMEP, 2014; Hayman et al., 2006; Sickles et al., 1999). However, many papers have shown that there are potential artefacts in filter-pack sampling for $\mathrm{HNO}_{3}$ and $\mathrm{HCl}$, due to interactions with $\mathrm{NH}_{3}$ and the volatility of $\mathrm{NH}_{4} \mathrm{NO}_{3}$ and $\mathrm{NH}_{4} \mathrm{Cl}$ aerosol (Pio, 1992; Sickles et al., 1999; Cheng et al., 2012). Results from EMEP filter pack measurements are therefore reported as TIN and TIA, due to phase uncertainties in the method (Tørseth et al., 2012). This has been complemented by daily measurements of $\mathrm{HNO}_{3}$ and $\mathrm{NO}_{3}^{-}$using annular denuders (Allegrini et al., 1987; EMEP, 2014) that are made at a restricted number of sites because of the resources required. In North America, filter pack sampling is also used in weekly measurements of sulfur and nitrogen species in the CASTnet (Clean Air Status Trends Network) national monitoring network of 95 sites across the contiguous USA, Canada, and Alaska (https://www.epa.gov/castnet, last access: 25 October 2018). At a small number of CASTnet sites, hourly measurements of water-soluble gases and aerosols are made with the Monitor for AeRosols and GAses in ambient air (MARGA) system (Rumsey and Walker, 2016).

High time-resolution measurements of gases and aerosols are useful at selected locations for detailed analysis and model testing, but the high costs and resources required for these measurements make them unsuitable for the assessment of long-term trends at many sites, particularly where spatial patterns are required. To achieve this, a larger number of sites operated at lower time-resolution is needed. In the UK, the Eutrophying and Acidifying Atmospheric Pollutants (UKEAP) network provides long-term measurements for the UK rural atmospheric concentrations and deposition of air pollutants that contribute to acidification and eutrophication processes (Conolly et al., 2016). UKEAP is comprised of two EMEP supersites and four component networks: precipitation network (Precip-net), $\mathrm{NO}_{2}$ diffusion tube network $\left(\mathrm{NO}_{2}\right.$ net), National Ammonia Monitoring Network (NAMN), and the Acid Gases and Aerosol Network (AGANet). At the two EMEP supersites (Auchencorth and Harwell - relocated to Chilbolton in 2016), semi-continuous hourly speciated measurements of reactive gases and aerosols are made with the MARGA system (Twigg et al., 2016). These measurements are contributing to the validation and improvement of atmospheric models, such as FRAME (Dore et al., 2015) and EMEP4UK (Vieno et al., 2014, 2016) that are used to de- velop and provide the evidence base for air quality policies, both nationally and internationally.

The long-term dataset of monthly speciated measurements from the AGANet (1999-2015) are analysed in this paper to provide a comprehensive assessment of the spatial, temporal, and long-term trends in atmospheric concentrations of the acid gases $\mathrm{HNO}_{3}, \mathrm{SO}_{2}, \mathrm{HCl}$ and related aerosol components $\mathrm{NO}_{3}^{-}, \mathrm{SO}_{4}^{2-}$ and $\mathrm{Cl}^{-}$(and also base cations $\mathrm{Na}^{+}, \mathrm{Ca}^{2+}$, and $\mathrm{Mg}^{2+}$ ) across the UK, together with an assessment of the DELTA denuder-filter pack sampling method (Sutton et al., 2001b; Tang et al., 2009) as compared with other sampling techniques. To aid interpretation of the relative changes and trends in the acid gases and aerosols, $\mathrm{NH}_{3}$ and particulate $\mathrm{NH}_{4}^{+}$data from the NAMN (Tang et al., 2018) are included, since atmospheric $\mathrm{NH}_{3}$ is a major interacting precursor gas in neutralization reactions with the acid gases.

\section{Methods}

\subsection{Acid Gases and Aerosol monitoring Network (AGANet)}

The UK Acid Gases and Aerosol Network (AGANet), known previously as the nitric acid monitoring network, was started in September 1999 under the Acid Deposition Monitoring Network (ADMN, Hayman et al., 2007) to deliver for the very first time, long-term monthly speciated measurement data on gaseous $\mathrm{HNO}_{3}$ and particulate $\mathrm{NO}_{3}^{-}$across the UK. Other acid gases $\left(\mathrm{SO}_{2}, \mathrm{HCl}\right)$ and aerosols $\left(\mathrm{SO}_{4}^{2-}, \mathrm{Cl}^{-}\right.$, plus base cations $\mathrm{Na}^{+}, \mathrm{Ca}^{2+}, \mathrm{Mg}^{2+}$ ) are also measured and reported.

AGANet and NAMN are closely integrated, with AGANet established at a subset of NAMN sites to provide additional speciated measurements of the acid gases and aerosol components. To improve on national coverage, the number of sites in AGANet was increased in 2006 from 12 to 30 (Fig. 1, Table 1). At the same time, the Rural Sulfur Dioxide Monitoring Program ceased, replaced by $\mathrm{SO}_{2}$ and $\mathrm{SO}_{4}^{2-}$ measurements made under the expanded AGANet (Hayman et al., 2007). A broad spatial coverage of the UK is provided by the AGANet sites, with a focus on sites providing parallel information on other air pollutants (e.g. collocation with the Automatic Urban and Rural Network that provides compliance monitoring against the Ambient Air Quality Directives (https://uk-air.defra.gov.uk/networks/, last access: 25 October 2018) and ecosystem assessments (e.g. Environmental Change Network, http://www.ecn.ac.uk/, last access: 25 October 2018) (Monteith et al., 2016).

\subsection{Extended DELTA methodology for sampling acid gases and aerosol in AGANet}

A low-cost manual denuder-filter pack method, DELTA (DEnuder for Long-Term Air sampling) implemented in the 
Table 1. List of sites in the UK Acid Gas and Aerosol Network (AGANet) with details of locations, start dates, and UK-AIR ID (https: //uk-air.defra.gov.uk/networks/network-info?view=aganet, last access: 23 October 2018).

\begin{tabular}{|c|c|c|c|c|}
\hline Site name & UK-AIR ID & Latitude & Longitude & Start \\
\hline Barcombe Mills & UKA00069 & 50.9191 & 0.0486 & Apr 2000 \\
\hline Bush OTC & UKA00128 & 55.8623 & -3.2058 & Sep 1999 \\
\hline Cwmystwyth & UKA00325 & 52.3524 & -3.8053 & Sep 1999 \\
\hline Eskdalemuir & UKA00130 & 55.3153 & -3.2061 & Sep 1999 \\
\hline Glensaugh & UKA00348 & 56.9072 & -2.5594 & Sep 1999 \\
\hline High Muffles & UKA00169 & 54.3349 & -0.8086 & Sep 1999 \\
\hline Lough Navar & UKA00166 & 54.4395 & -7.9003 & Oct 1999 \\
\hline Rothamsted & UKA00275 & 51.8065 & -0.3604 & Sep 1999 \\
\hline Stoke Ferry & UKA00317 & 52.5599 & 0.5061 & Sep 1999 \\
\hline Strathvaich & UKA00162 & 57.7345 & -4.7766 & Sep 1999 \\
\hline Sutton Bonington & UKA00312 & 52.8366 & -1.2512 & Sep 1999 \\
\hline Yarner Wood & UKA00168 & 50.5976 & -3.7165 & Sep 1999 \\
\hline \multicolumn{5}{|c|}{ New sites added from January 2006} \\
\hline Auchencorth Moss & UKA00451 & 55.7922 & -3.2429 & Jan 2006 \\
\hline Caenby & UKA00492 & 53.3979 & -0.5074 & Feb 2006 \\
\hline Carradale & UKA00389 & 55.5825 & -5.4962 & Jan 2006 \\
\hline Detling & UKA00481 & 51.3079 & 0.5827 & Feb 2006 \\
\hline Edinburgh St Leonards & UKA00454 & 55.9456 & -3.1822 & Jan 2006 \\
\hline Goonhilly & UKA00056 & 50.0506 & -5.1815 & Jan 2006 \\
\hline Halladale & UKA00314 & 58.4124 & -3.8758 & Jan 2006 \\
\hline Harwell & UKA00047 & 51.5711 & -1.3253 & May 2006 \\
\hline Hillsborough & UKA00293 & 54.4525 & -6.0833 & Jan 2006 \\
\hline Ladybower & UKA00171 & 53.4034 & -1.7520 & Feb 2006 \\
\hline Lagganlia & UKA00290 & 57.1110 & -3.8921 & Jan 2006 \\
\hline Lerwick & UKA00486 & 60.1392 & -1.1853 & Jan 2006 \\
\hline London, Cromwell Road 2 & UKA00370 & 51.4955 & -0.1787 & Jan 2006 \\
\hline Moorhouse & UKA00357 & 54.6901 & -2.3769 & Jan 2006 \\
\hline Narberth & UKA00323 & 51.7818 & -4.6915 & Mar 2006 \\
\hline Plas y Brenin & UKA00493 & 53.1018 & -3.9179 & May 2006 \\
\hline Rosemaund & UKA00491 & 52.1214 & -2.6363 & Jan 2006 \\
\hline Rum & UKA00276 & 57.0100 & -6.2718 & Feb 2006 \\
\hline
\end{tabular}

NAMN for measurement of $\mathrm{NH}_{3}$ gas and aerosol $\mathrm{NH}_{4}^{+}$(Sutton et al., 2001a, b; Tang et al., 2018) is extended to provide additional simultaneous monthly time-integrated average concentrations of acid gases $\left(\mathrm{HNO}_{3}, \mathrm{SO}_{2}, \mathrm{HCl}\right)$ and particulate phase $\mathrm{NO}_{3}^{-}, \mathrm{SO}_{4}^{2-}, \mathrm{Cl}^{-}, \mathrm{Na}^{+}, \mathrm{Ca}^{2+}$, and $\mathrm{Mg}^{2+}$ for the AGANet (Conolly et al., 2016; Tang et al., 2015).

The DELTA method used in AGANet has also been applied in an extensive European-scale network of 58 sites to deliver 4 years of atmospheric concentrations and deposition data for reactive trace gas and aerosols from 2006 to 2009 (Tang et al., 2009; Flechard et al., 2011). Detailed descriptions of the DELTA method are provided by Sutton et al. (2001b) and by Tang et al. (2009, 2015). In brief, a small air pump is used to provide low sampling rates of $0.2-0.4 \mathrm{~L} \mathrm{~min}^{-1}$, and air volumes are measured by a highsensitivity diaphragm gas meter. By sampling air slowly, the method is optimized for monthly measurements, with sufficient sensitivity to resolve low concentrations at clean back- ground sites (e.g. $\mathrm{LOD}=0.05 \mu \mathrm{gm}^{-3}$ for $\mathrm{HNO}_{3}$ for monthly sampling; see Tables S1, S2). In addition, the power requirement is very small, and low voltage versions (using 6 and $12 \mathrm{~V}$ micro-air pumps) of the system powered by wind-solar energy operate at some remote sites.

An extended denuder-filter pack sampling train is used to provide speciated sampling of reactive gases and aerosols (Fig. S1) (Tang et al., 2009, 2015). A Teflon inlet $(2.8 \mathrm{~cm}$ long) at the front end ensures development of a laminar air stream (Table S3), followed by a first pair of $\mathrm{K}_{2} \mathrm{CO}_{3}$ and glycerol coated denuders to collect $\mathrm{HNO}_{3}, \mathrm{SO}_{2}$, and $\mathrm{HCl}$, a second pair of citric acid coated denuders to collect $\mathrm{NH}_{3}$ and a 2-stage filter pack at the end to collect aerosol components. Stage 1 of the filter pack is a cellulose filter impregnated with $\mathrm{K}_{2} \mathrm{CO}_{3}$ and glycerol to collect $\mathrm{NO}_{3}^{-}, \mathrm{SO}_{4}^{2-}, \mathrm{Cl}^{-}, \mathrm{Na}^{+}, \mathrm{Ca}^{2+}$, $\mathrm{Mg}^{2+}$, with evolved aerosol $\mathrm{NH}_{4}^{+}$from this filter collected on the stage 2 citric acid impregnated filter. The separation of gases and aerosol is achieved by higher diffusivities of re- 


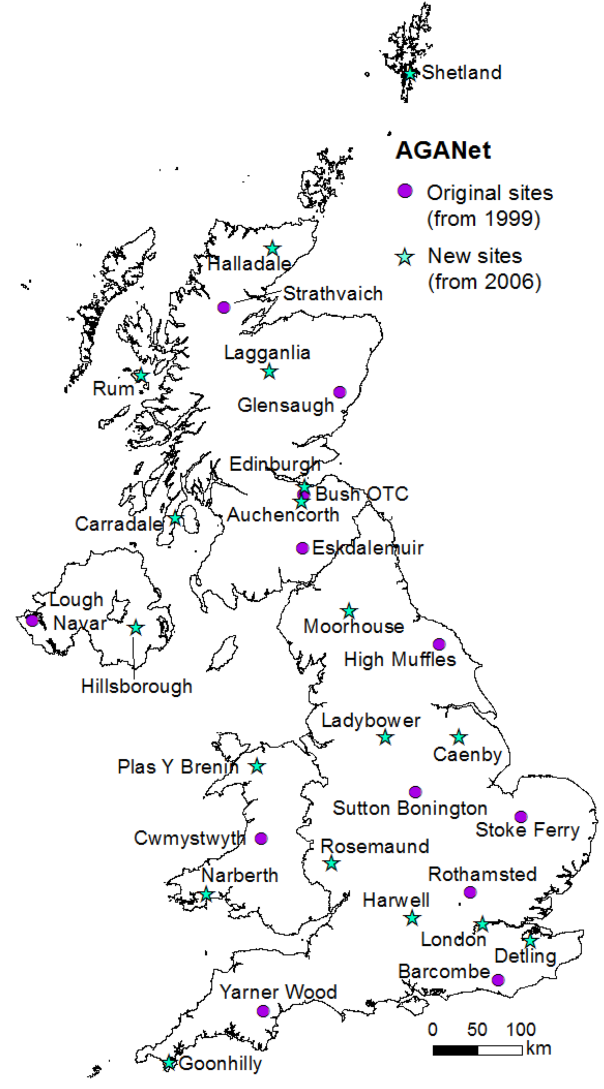

Figure 1. Site map of the UK Acid Gases and Aerosol Network (AGANet). The AGANet was established in September 1999 with 12 sites and expanded to 30 sites from January 2006 to improve national coverage. These sites also provide measurements of $\mathrm{NH}_{3}$ and $\mathrm{NH}_{4}^{+}$for the UK National Ammonia Monitoring Network (NAMN, Tang et al., 2018).

active gases to the denuder walls where they react with the chemical coating and are retained, whereas aerosol components pass through and are retained by post-denuder filters (Ferm, 1979). In this approach, potential artefacts caused by phase interactions associated with filter packs and bubblers are avoided (e.g. Sickles et al., 1999). A particle size cutoff of around $4.5 \mu \mathrm{m}$ was estimated for the DELTA air inlet (Tang et al., 2015). The DELTA will therefore also sample fine mode aerosols in the $\mathrm{PM}_{2.5}$ fraction, as well as some of the coarse mode aerosols $<\mathrm{PM}_{4.5}$.

$\mathrm{Na}_{2} \mathrm{CO}_{3}$ is reported to be an effective sorbent for acid gases, allowing simultaneous collection of $\mathrm{HNO}_{3}, \mathrm{SO}_{2}$, and $\mathrm{HCl}$ on denuders (e.g. Ferm, 1986), but since the measurement of aerosol $\mathrm{Na}^{+}$is also of key interest in AGANet, a $\mathrm{K}_{2} \mathrm{CO}_{3}$ coating is used instead to eliminate possible $\mathrm{Na}^{+}$ contamination from $\mathrm{Na}_{2} \mathrm{CO}_{3}$. Glycerol is added to increase adhesion, stabilize the base coating (Ferm, 1986; Finn et al., 2001) and to minimize potential oxidation of nitrite that is also collected on the denuder to nitrate in the presence of atmospheric oxidants such as ozone (Allegrini et al., 1987;
Perrino et al., 1990). The lengths of denuders (borosilicate glass tubes 10 and $15 \mathrm{~cm}$ long to capture $>95 \%$ of $\mathrm{NH}_{3}$ and acid gases, respectively) in the sampling train was calculated according to the procedures described by Sutton et al. (2001b), based on the calculations derived by Gormley and Kennedy (1948) and Ferm (1979); see Table S3. All sites were set up as "outdoor" systems sampling directly from the atmosphere, avoiding potential adsorption losses (in particular $\mathrm{HNO}_{3}$, which is highly surface active) and artefacts in air inlet lines. The sampling train is installed inside a simple watertight housing (Fig. S1), which is mounted on a steel post in the desired location. A low density polyethylene funnel $(89 \mathrm{~mm}$ aperture) is placed at the inlet as a rain shelter, and sampling height is approx. $1.5 \mathrm{~m}$.

\subsection{Chemical analysis}

$\mathrm{K}_{2} \mathrm{CO}_{3}$ / glycerol-coated denuders and aerosol filters are extracted into $5 \mathrm{~mL}$ of deionized $\mathrm{H}_{2} \mathrm{O}$ for analysis. Anions $\left(\mathrm{NO}_{3}^{-}, \mathrm{SO}_{4}^{2-}\right.$, and $\left.\mathrm{Cl}^{-}\right)$in the denuder and filter extracts are analysed by ion chromatography (IC). Base cations $\mathrm{Na}^{+}$, $\mathrm{Mg}^{2+}$ and $\mathrm{Ca}^{2+}$ from the filter extracts were analysed by IC between 1999-June 2008 and by inductively coupled plasma-optical emission spectroscopy (ICP-OES/ICP-AES) from July 2008. Citric acid coated denuders and filter papers are also extracted into deionized $\mathrm{H}_{2} \mathrm{O}(3$ and $4 \mathrm{~mL}$, respectively), with analysis of $\mathrm{NH}_{4}^{+}$performed on a high sensitivity ammonia flow injection analysis system, as described in Tang et al. (2018).

Up to June 2009, analyses were carried out at Harwell Laboratory (Hayman et al., 2007) and from July 2009 at CEH Lancaster (Conolly et al., 2016). The limit of detection (LOD) for the DELTA method for the different components are calculated by analysing a series of laboratory blanks. The mean and standard deviation of the results are calculated and the LOD is calculated as 3 times the standard deviation divided by $15 \mathrm{~m}^{3}$, the typical volume of air sampled over a month by the DELTA system. Details of changes in laboratory, analytical methods, and LODs for the gases and aerosols are summarized in Tables S1 and S2, respectively.

\subsection{Calculation of air concentrations}

The air concentration $\left(\chi_{\mathrm{a}}\right)$ of a gas or aerosol is calculated according to Eq. (1) (see Sutton et al., 2001b, Tang et al., 2018):

$\chi_{\mathrm{a}}=\frac{Q}{V}$,

where $Q$ is the amount of a gas or aerosol collected on a denuder or aerosol filter, and $V$ is the volume of air sampled (from gas meter, typically $15 \mathrm{~m}^{3}$ in a month).

The denuder capture efficiency for each of the gas is calculated by comparing the concentrations of the individual gases in the denuder pairs (Eq. 2) and are applied in an infinite se- 
ries correction on the raw data to provide corrected air concentrations $\left(\chi_{\mathrm{a} \text { (corrected) }}\right)$ according to Eq. (3) (see Sutton et al., 2001b; Tang et al., 2018).

Denuder capture efficiency $(\% \mathrm{CE})=$

$$
\begin{aligned}
& 100 \times \frac{\text { Denuder } 1}{(\text { Denuder } 1+\text { Denuder } 2)} \\
& \chi_{\mathrm{a}}(\text { corrected })=\chi_{\mathrm{a}}(\text { Denuder } 1) \times \frac{1}{1-\chi_{\mathrm{a}}\left[\frac{\chi_{\mathrm{a}}(\text { Denuder } 2)}{\chi_{\mathrm{a}}(\text { Denuder } 1)}\right]}
\end{aligned}
$$

Sutton et al. (2001b) and Tang et al. (2003) have shown that this procedure provides an important quality control, flagging up occurrences of poorly coated denuders and/or sampling issues. With denuder capture efficiency better than $90 \%$, the correction represents $<1 \%$ of the corrected air concentration of the gas. Below $60 \%$, the correction is large (>50\%) and is not applied, and the air concentration is then calculated as the sum of concentrations of the denuder pair. The amount of correction for gas not captured that is added to the corrected gas concentration, is subtracted from the estimated aerosol concentrations of matching anions and cations (see Tang et al., 2018).

\subsection{Data quality control}

The following data quality checks are applied to the network data, as part of the network quality management system (Tang and Sutton, 2003; Conolly et al., 2016).

i. Air flow rate $\left(0.2-0.4 \mathrm{~L} \mathrm{~min}^{-1}\right)-$ where this is below the expected range for a sampling period, the data are flagged as valid but failing the QC standard.

ii. Denuder capture efficiency - where this is less than $75 \%$ for a sample, the data are flagged as valid but less certain.

iii. Ion balance checks - close agreement expected between $\mathrm{NH}_{4}^{+}$and the sum of $\mathrm{NO}_{3}^{-}$and $2 \times \mathrm{SO}_{4}^{2-}$, as $\mathrm{NH}_{3}$ is neutralized by $\mathrm{HNO}_{3}$ and $\mathrm{H}_{2} \mathrm{SO}_{4}$ to form $\mathrm{NH}_{4} \mathrm{NO}_{3}$ and $\left(\mathrm{NH}_{4}\right)_{2} \mathrm{SO}_{4}$, respectively (Conolly et al., 2016), and for $\mathrm{Na}^{+}$and $\mathrm{Cl}^{-}$, as these are marine (sea salt) in origin.

iv. Screening the whole dataset for sampling anomalies and outliers, e.g. due to contamination or other issues.

\section{6 $\mathrm{HNO}_{3}$ measurement artefact and correction}

Tang et al. $(2009,2015)$ have identified that $\mathrm{HNO}_{3}$ concentrations $\left(\mathrm{NO}_{3}^{-}\right.$on denuders assumed to be from $\left.\mathrm{HNO}_{3}\right)$ may be overestimated on carbonate coated denuders, due to partial co-collection of other oxidized nitrogen components such as nitrous acid (HONO). In the case of HONO, this collects on the denuder carbonate coating as nitrite $\left(\mathrm{NO}_{2}^{-}\right)$, but oxidizes to nitrate $\left(\mathrm{NO}_{3}^{-}\right)$in the presence of oxidants such as ozone (Bytnerowicz et al., 2005) which can result in a positive interference in $\mathrm{HNO}_{3}$ determination (Tang et al., 2009,
2015). Other oxidized nitrogen species present in the atmosphere such as peroxyacetyl nitrate (PAN) and nitrogen oxides $\left(\mathrm{NO}_{x}\right)$ can also potentially contribute to a further small interference (Allegrini et al., 1987; Bai et al., 2003). Based on the tests of Tang et al. (2015), raw $\mathrm{HNO}_{3}$ data are corrected with an empirical factor of 0.45 which is estimated to be uncertain by $\pm 30 \%$. Apart from where stated, all $\mathrm{HNO}_{3}$ data reported in this study have the 0.45 correction factor applied.

\subsection{Time series trend analyses}

Statistical trend analyses using both parametric linear regression (LR) and non-parametric Mann-Kendall (MK) (Gilbert, 1987; Chatfield, 2016) tests were performed on annually averaged data from AGANet, and on a subset of annually averaged data from NAMN made at the same AGANet sites. The datasets are considered sufficiently long-term ( $>10$ years) and produced by a consistent method for effective statistical trend analyses. Both the LR and MK approaches are widely adopted for trend analyses in long-term atmospheric data (e.g. Meals et al., 2011; Colette et al., 2016; Jones and Harrison, 2011; Marchetto et al., 2013; Hayman et al., 2007; Conolly et al., 2016), and were used in a recent trend assessment of atmospheric $\mathrm{NH}_{3}$ and $\mathrm{NH}_{4}^{+}$data (1998-2014) from the NAMN (Tang et al., 2018). As described in Tang et al. (2018), LR tests were performed using R, and MK tests used the R "Kendall" package (McLeod, 2015), with estimation of the MK Sen's slope (fitted median slope of a linear regression joining all pairs of observations) and confidence interval of the fitted trend using the R "Trend" package (Pohlert, 2016). Results from both tests provides an indication of uncertainty associated with the choice of approach. Since there was no difference between either tests, MK results only are presented and discussed in the paper. A comparison of trend analyses from both approaches is however provided in supplementary materials (Figs. S6 and S7 and Tables S4-S6).

\section{Results and discussion}

\subsection{Performance of the DELTA method}

This section presents the performance of the DELTA measurements, including a comparison with other air sampling methods and networks. Replicated sampling with the DELTA method were also made to assess measurement reproducibility and this is shown for example for the Bush OTC site in Scotland (UKA00128). A comparison of the parallel measurements (Fig. 2) showed good reproducibility in the method, with close agreement for all components (e.g. mean difference of $< \pm 3 \%$ for all components and $\pm 6 \%$ for $\mathrm{HCl}$ ). 
(a) Gases $\left(\mathrm{HNO}_{3}, \mathrm{SO}_{2}, \mathrm{HCl}, \mathrm{NH}_{3}\right)$
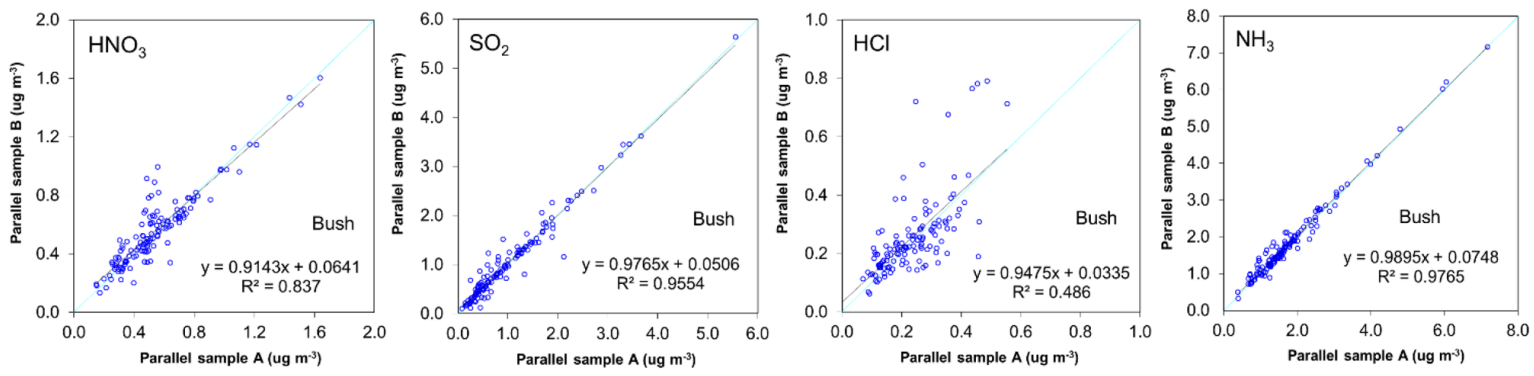

(b) Particulate $\left(\mathrm{NO}_{3}^{-}, \mathrm{SO}_{4}{ }^{2-}, \mathrm{Cl}^{-}, \mathrm{NH}_{4}^{+}\right)$
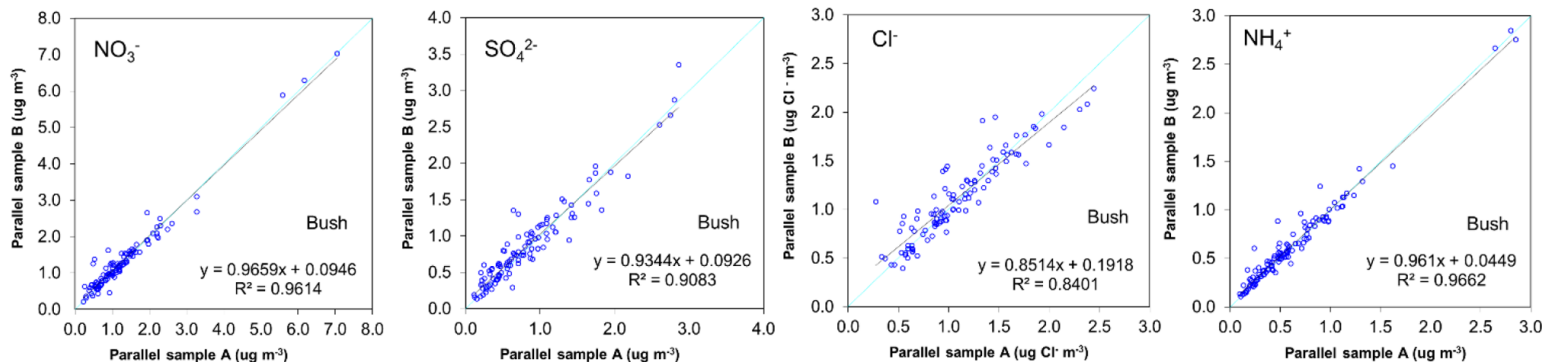

(c) Summary of regression analysis

\begin{tabular}{|c|c|c|c|c|c|c|c|c|}
\hline & \multicolumn{4}{|l|}{ Gases } & \multicolumn{4}{|c|}{ Particulates } \\
\hline & $\mathrm{HNO}_{3}$ & $\mathrm{SO}_{2}$ & $\mathrm{HCl}$ & $\mathrm{NH}_{3}$ & $\mathrm{NO}_{3}{ }^{-}$ & $\mathrm{SO}_{4}{ }^{2-}$ & $\mathrm{Cl}^{-}$ & $\mathrm{NH}_{4}^{+}$ \\
\hline$R^{2}$ & $0.837 * * *$ & $0.955^{* * *}$ & $0.486 * * *$ & $0.976 * * *$ & $0.961 * * *$ & $0.908^{* * *}$ & $0.840 * * *$ & $0.966 * * *$ \\
\hline Slope & $0.914 *$ & $0.976^{n s}$ & $0.947^{\text {ns }}$ & $0.989^{n s}$ & $0.966^{n s}$ & $0.934^{*}$ & $0.851 * * *$ & $0.961 *$ \\
\hline Intercept & $0.064 * *$ & $0.051^{*}$ & $0.033^{n s}$ & $0.075^{* *}$ & $0.095 * *$ & $0.093^{* *}$ & $0.192 * * *$ & $0.045^{* * * *}$ \\
\hline No. observations $(n)$ & 130 & 130 & 128 & 140 & 108 & 108 & 104 & 119 \\
\hline Mean $\mathrm{A}\left(\mu \mathrm{g} \mathrm{m}^{-3}\right)$ & 0.54 & 1.02 & 0.23 & 1.75 & 1.29 & 0.84 & 1.09 & 0.61 \\
\hline Mean B $\left(\mu \mathrm{g} \mathrm{m}^{-3}\right)$ & 0.56 & 1.05 & 0.25 & 1.80 & 1.34 & 0.87 & 1.12 & 0.63 \\
\hline
\end{tabular}

Figure 2. Comparisons of parallel measurement of monthly (a) atmospheric reactive gases $\left(\mathrm{HNO}_{3}, \mathrm{SO}_{2}, \mathrm{HCl}\right.$, and $\left.\mathrm{NH}_{3}\right)$ and $(\mathbf{b})$ particulate $\left(\mathrm{NO}_{3}^{-}, \mathrm{SO}_{4}^{2-}, \mathrm{Cl}^{-}\right.$, and $\left.\mathrm{NH}_{4}^{+}\right)$concentrations from duplicate DELTA sampling at the UK Acid Gas and Aerosol Monitoring Network (AGANet) and National Ammonia Monitoring Network (NAMN) site Bush OTC (UKA00128) in southern Scotland for the period 1999 to 2015. (c) A summary of the regression analyses. Each point represents a comparison between the paired monthly DELTA measurements.

\subsubsection{Comparison with daily annular denuder measurements}

An assessment of the DELTA method for $\mathrm{NH}_{3}$ has previously been reported by Sutton et al. (2001b). Following the extension to additionally sample acid gases and aerosols, the modified system was compared with independent daily measurements from an annular denuder system (ADS). The ADS (ChemspecTM model 2500 air sampling system, R\&P Co. Inc.) was operated at Barcombe Mills in southern England (UKA00069) alongside the AGANet DELTA monthly measurements for a period of 18 months. Due to significant instrument and local site issues resulting in low data capture with the ADS, only 11 months of data were available for intercomparison. The sampling train used in the ADS consisted of $2 \mathrm{~K}_{2} \mathrm{CO}_{3}$ / glycerol-coated annular denuders (same coating as AGANet DELTA), 2 citric acid-coated annular denuders; a cyclone with $2.5 \mu \mathrm{m}$ cut-off, followed by a 2 stage filter pack containing a $2 \mu \mathrm{m}$ PALL Zefluor teflon mem- brane (collection of $\mathrm{NO}_{3}^{-}, \mathrm{SO}_{4}^{2-}, \mathrm{Cl}^{-}, \mathrm{Na}^{+}, \mathrm{Mg}^{2+}, \mathrm{Ca}^{2+}$ ) and a $1 \mu \mathrm{m}$ PALL Nylasorb nylon membrane (collection of evolved $\mathrm{NO}_{3}^{-}$), with a sampling rate of $10 \mathrm{~L} \mathrm{~min}^{-1}$. To compare against the monthly DELTA measurements, daily ADS values were averaged to the corresponding monthly periods, with results summarized in Fig. 3.

In the measurement of gases, $\mathrm{HNO}_{3}$ determination on DELTA (mean $=1.56 \mathrm{HNO}_{3} \mu \mathrm{g} \mathrm{m}^{-3}, n=11$ ) was on average $23 \%$ higher than the ADS (mean $=1.31 \mathrm{HNO}_{3} \mu \mathrm{g} \mathrm{m}^{-3}$, $n=11$ ). Since both methods used the same carbonate coating on the denuders to sample acid gases, the $\mathrm{HNO}_{3}$ data here have not been corrected with the empirical factor described in Sect. 2.6. Nitrous acid (HONO) was found to be close to or below limit of detections for most of the DELTA measurements $\left(\right.$ mean $=$ of $0.03 \mu \mathrm{g} \mathrm{HONO} \mathrm{m}^{-3}$ ), compared with a significantly higher concentration (mean $=0.41$ HONO $\mu \mathrm{g} \mathrm{m}^{-3}$ ) from the ADS. Since the sampling period of the ADS is daily, any HONO collected as nitrite on the ADS is likely to remain as nitrite and not oxidized to 

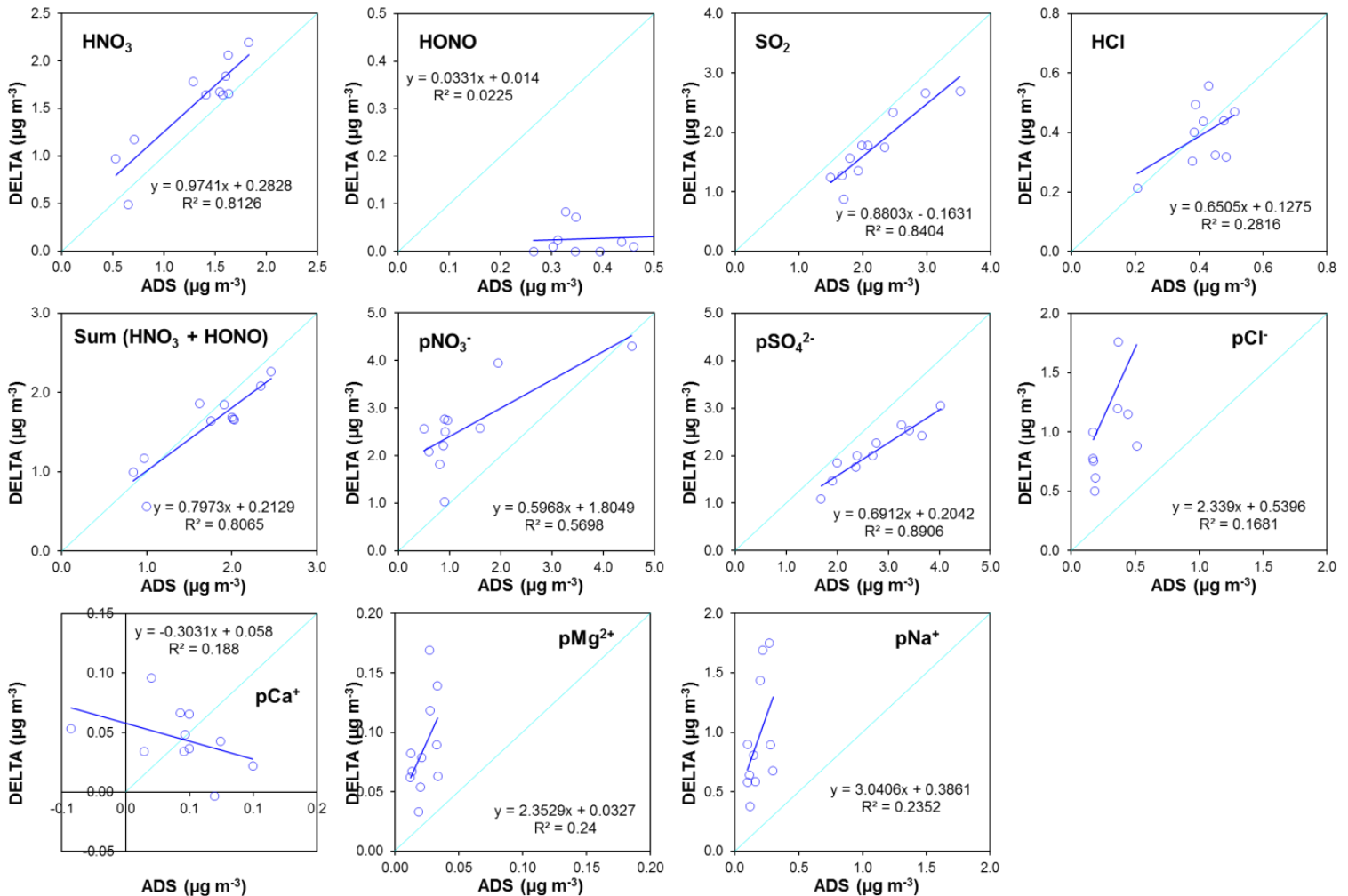

\begin{tabular}{|c|c|c|c|c|c|c|c|c|c|c|c|}
\hline & Gases & & & & & Particulates & & & & & \\
\hline & $\mathrm{HNO}_{3}$ & $\left(\mathrm{HNO}_{3}+\mathrm{HONO}\right)$ & HONO & $\mathrm{SO}_{2}$ & $\mathrm{HCl}$ & $\mathrm{NO}_{3}{ }^{-}$ & $\mathrm{SO}_{4}{ }^{2-}$ & $\mathrm{Cl}^{-}$ & $\mathrm{Na}^{+}$ & $\mathrm{Ca}^{2+}$ & $\mathbf{M g}^{2+}$ \\
\hline $\begin{array}{l}\text { Linear } \\
\text { regression: } R^{2}\end{array}$ & $0.813^{* \star *}$ & $0.806^{\star * *}$ & $0.022^{n s}$ & $0.840^{* \star *}$ & $0.282^{\text {ns }}$ & $0.570^{* *}$ & $0.891^{* * *}$ & $0.168^{\text {ns }}$ & $0.813^{\star * *}$ & $0.188^{n s}$ & $0.24^{n s}$ \\
\hline slope & $0.974^{\text {ns }}$ & $0.797^{n s}$ & $0.033^{\star * *}$ & $0.880^{n s}$ & $0.650^{\text {ns }}$ & $0.570^{*}$ & $0.691^{\text {** }}$ & $2.339^{n s}$ & $0.974^{\text {ns }}$ & -0.303 & 2.353 \\
\hline intercept & $0.283^{\text {ns }}$ & $0.213^{\text {ns }}$ & $0.014^{n s}$ & $-0.163^{n s}$ & $0.127^{\text {ns }}$ & $1.809^{\star * \star}$ & $0.204^{\text {ns }}$ & $0.540^{n s}$ & $0.283^{\text {ns }}$ & $0.058^{\star * *}$ & $0.033^{\text {ns }}$ \\
\hline Observations: $n$ & 11 & 11 & 11 & 11 & 10 & 11 & 11 & 11 & 11 & 11 & 11 \\
\hline $\begin{array}{l}\text { mean DELTA } \\
\left(\mu \mathrm{g} \mathrm{m}^{-3}\right)\end{array}$ & 1.56 & 1.58 & 0.03 & 1.75 & 0.40 & 2.59 & 2.10 & 1.24 & 1.56 & 0.05 & 0.09 \\
\hline $\begin{array}{l}\text { mean ADS } \\
\left(\mu \mathrm{g} \mathrm{m}^{-3}\right)\end{array}$ & 1.31 & 1.72 & 0.41 & 2.18 & 0.41 & 1.32 & 2.74 & 0.30 & 1.31 & 0.04 & 0.02 \\
\hline
\end{tabular}

Figure 3. Comparison of $\mathrm{HNO}_{3}, \mathrm{HONO}$, sum $\left(\mathrm{HNO}_{3}+\mathrm{HONO}\right), \mathrm{SO}_{2}, \mathrm{HCl}$ and aerosol $\mathrm{NO}_{3}^{-}, \mathrm{SO}_{4}^{2-}, \mathrm{Cl}^{-}, \mathrm{Na}^{+}, \mathrm{Ca}^{2+}, \mathrm{Mg}^{2+}$ concentrations by the Acid Gases and Aerosol Network (AGANet) DELTA method with available measurements from the collocated ChemSpec Daily Annular Denuder system (ADS) at Barcombe Mills (UKA00069). Mean concentrations were derived from the average of daily ADS data for the corresponding DELTA sampling periods (monthly). $\mathrm{HNO}_{3}$ values shown for DELTA and ADS are as calculated from the amount of $\mathrm{NO}_{3}^{-}$collected on the denuders and have not been adjusted by a bias correction factor (see Sect. 2.6). A summary of the regression analyses is provided in the table below the graphs.

nitrate. The very low HONO (nitrite on the denuders assumed to be from HONO) concentrations from the DELTA supports the hypothesis of the retention of HONO that is subsequently oxidized to nitrate, resulting in an artefact in $\mathrm{HNO}_{3}$ determination (Possanzini et al., 1983; Allegrini et al., 1987; Tang et al., 2015). Further corroboration is provided by the improved agreement between both methods (line of fit closer to the $1: 1$ line) when comparing the sum of $\mathrm{HNO}_{3}$ and $\mathrm{HONO}$ (Fig. 3). Agreement between the DELTA and ADS was within $19 \%$ for $\mathrm{SO}_{2}$ (mean DELTA $=1.75 \mu \mathrm{g} \mathrm{m}^{-3}$ cf. mean $\mathrm{ADS}=2.18 \mu \mathrm{g} \mathrm{m}^{-3}$ ) and $4 \%$ for $\mathrm{HCl}$ (mean DELTA $=0.40 \mu \mathrm{g} \mathrm{m}^{-3}$ cf. mean
$\left.\operatorname{ADS}=0.41 \mu \mathrm{g} \mathrm{m}^{-3}\right)$. Given the limited data available, it is not clear why $\mathrm{SO}_{2}$ measured on the ADS is higher than the DELTA, since there was good agreement for $\mathrm{HCl}$.

For the particle-phase components, $\mathrm{NO}_{3}^{-}$measured by the DELTA method (mean $=2.59 \mu \mathrm{g} \mathrm{NO}_{3}^{-} \mathrm{m}^{-3}$ ) was on average 2-fold higher than the ADS method $\left(\right.$ mean $=1.32 \mu \mathrm{g} \mathrm{NO}_{3}^{-} \mathrm{m}^{-3}$ ), whereas $\mathrm{SO}_{4}^{2-}$ by the DELTA method was on average $23 \%$ lower $($ DELTA $=2.10$ vs $\left.\mathrm{ADS}=2.74 \mu \mathrm{g} \mathrm{SO}_{4}^{2-} \mathrm{m}^{-3}\right)$ (Fig. 3). $\mathrm{NO}_{3}^{-}$and $\mathrm{SO}_{4}^{2-}$ are both present as fine mode $(<1 \mu \mathrm{m}) \mathrm{NH}_{4} \mathrm{NO}_{3}$ and $\left(\mathrm{NH}_{4}\right)_{2} \mathrm{SO}_{4}$ (Putaud et al., 2010). Some $\mathrm{NO}_{3}^{-}$can also be present in the coarse mode $(>2.5 \mu \mathrm{m})$, likely as calcium nitrate 

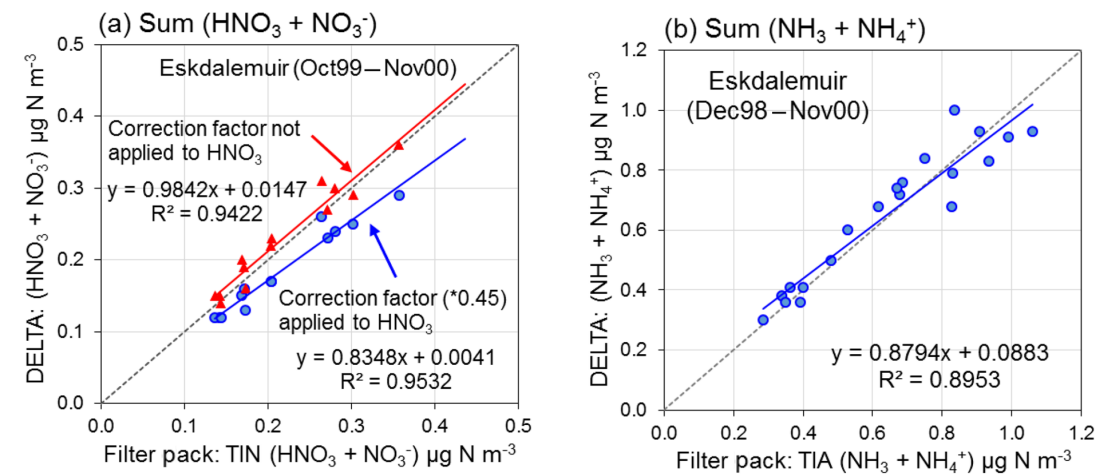

\begin{tabular}{|c|c|c|c|c|c|c|}
\hline & $\begin{array}{l}\text { DELTA } \\
\text { TIN }\end{array}$ & $\begin{array}{l}\text { EMEP } \\
\text { TIN }\end{array}$ & $\begin{array}{c}\text { DELTA TIN } \\
\text { (corrected } \mathrm{HNO}_{3} \text { ) }\end{array}$ & $\begin{array}{l}\text { EMEP } \\
\text { TIN }\end{array}$ & $\begin{array}{c}\text { DELTA } \\
\text { TIA }\end{array}$ & $\begin{array}{c}\text { EMEP } \\
\text { TIA }\end{array}$ \\
\hline Linear regression: $R^{2}$ & \multicolumn{2}{|l|}{$0.942^{\star * \star}$} & \multicolumn{2}{|l|}{$0.953^{* \star *}$} & \multicolumn{2}{|l|}{$0.895^{\star \star \star}$} \\
\hline Slope & \multicolumn{2}{|l|}{$0.984^{n s}$} & \multicolumn{2}{|l|}{$0.835^{\star}$} & \multicolumn{2}{|l|}{$0.879^{\text {ns }}$} \\
\hline Intercept & \multicolumn{2}{|l|}{$0.015^{n s}$} & \multicolumn{2}{|l|}{$0.004^{n s}$} & \multicolumn{2}{|l|}{$0.088^{\text {ns }}$} \\
\hline Mean $\left(\mu \mathrm{g} \mathrm{N} \mathrm{m}{ }^{-3}\right)$ & 0.23 & 0.22 & 0.19 & 0.22 & 0.58 & 0.54 \\
\hline No. of observations $(n)$ & 13 & 13 & 13 & 13 & 13 & 13 \\
\hline
\end{tabular}

Significance level (slope different from 1, intercept $=0$ ): $* p<0.05, * * p<0.01$, ${ }^{* * *} p<0.001 . n s=$ not significant $(p>0.05)$

Figure 4. Comparison of (a) total inorganic nitrate, $\mathrm{TIN}$ ( sum of $\mathrm{HNO}_{3}+\mathrm{NO}_{3}^{-}$) and (b) total inorganic ammonium, $\mathrm{TIA}\left(\right.$ sum of $\mathrm{NH}_{3}+\mathrm{NH}_{4}^{+}$) concentrations at the Eskdalemuir monitoring station (EMEP station code $=$ GB0002R; UK-AIR ID $=$ UKA00130) measured under the EMEP program with concentrations of the corresponding gas and aerosol from the UK Acid Gases and $\mathrm{Aerosol}_{(\mathrm{AGANet}} \mathrm{HNO}_{3}$ and $\left.\mathrm{NO}_{3}^{-}\right)$ and UK National Ammonia Monitoring Network (NAMN, $\mathrm{NH}_{3}$ and $\mathrm{NH}_{4}^{+}$). EMEP values (EMEP, 2017a) are means of daily measurements for TIN and TIA by the EMEP filter pack method, matched to the AGANet and NAMN sampling periods (monthly). Filter pack measurements at Eskdalemuir terminated in December 2000. A summary of the regression analyses is provided in the table below the graphs.

$\left(\mathrm{Ca}\left(\mathrm{NO}_{3}\right)_{2}\right)$ from a reaction between gas-phase $\mathrm{HNO}_{3}$ (or its precursors) and soil dust particles (Putaud et al., 2010), while some of the $\mathrm{SO}_{4}^{2-}$ will be coarse mode sea salt $\mathrm{SO}_{4}^{2-}$ (see Sect. 3.5). A particle size cut-off of $4.5 \mu \mathrm{m}$ was estimated for the DELTA air inlet) (Tang et al., 2015), so the DELTA will also sample a small amount of coarse mode aerosols. An ion balance check of the ratio of $\mu$ eq. $\mathrm{NH}_{4}^{+}$to sum $\mu$ eq. $\left(\mathrm{NO}_{3}^{-}+\mathrm{SO}_{4}^{2-}\right)$ yielded a near unity value, confirming that $\mathrm{NO}_{3}^{-}$and $\mathrm{SO}_{4}^{2-}$ collected by the DELTA aerosol filter are mainly fine mode $\mathrm{NH}_{4} \mathrm{NO}_{3}$ and $\left(\mathrm{NH}_{4}\right)_{2} \mathrm{SO}_{4}$. In comparison, the ADS has a $2.5 \mu \mathrm{m}$ cyclone in front of the aerosol filters to collect aerosols $<2.5 \mu \mathrm{m}$ on the aerosol filters. $\mathrm{NH}_{4}^{+}$ was unfortunately not analysed in these tests, which would have allowed a similar ion balance check. $\mathrm{Na}^{+}$and $\mathrm{Cl}^{-}$ concentrations on the DELTA were also on average $331 \%$ and $444 \%$ higher than on the ADS and the ion balance check of the ratio of $\mathrm{Na}^{+}: \mathrm{Cl}^{-}$was unity for both methods. In the absence of analytical errors, loss of $\mathrm{NO}_{3}^{-}, \mathrm{Na}^{+}$and $\mathrm{Cl}^{-}$on the surface of the cyclone, coupled to a small fraction of the aerosols $>2.5 \mu \mathrm{m}$ that is collected (but not analysed) in the cyclone, could partly account for the observed lower concentrations of the aerosol components. Since $\mathrm{Ca}^{2+}$ and $\mathrm{Mg}^{2+}$ concentrations by both methods were at or below detection limits, comparisons of these are not meaningful and have not been made.

\subsubsection{Comparisons with filter pack measurements: $\mathrm{HNO}_{3} / \mathrm{NO}_{3}^{-}$and $\mathrm{NH}_{3} / \mathrm{NH}_{4}^{+}$}

The EMEP network (http://www.emep.int/, last access: 17 March 2017) measures atmospheric concentrations and depositions of a wide range of pollutants at rural background sites across Europe (Aas, 2014; Tørseth et al., 2012). A daily filter pack method continues to be implemented at 39 sites across Europe for assessment of oxidized and reduced nitrogen species, with results reported as total inorganic nitrate (TIN: $\mathrm{HNO}_{3}+\mathrm{NO}_{3}^{-}$) and total inorganic ammonia (TIA: $\mathrm{NH}_{3}+\mathrm{NH}_{4}^{+}$) (Colette et al., 2016; Tørseth et al., 2012), as these are considered more reliable than reporting for the gas and aerosol components separately.

At the UK Eskdalemuir site (EMEP station code GB0002R; UKAIR ID UKA00130), a Scottish rural background site on the border between Scotland and England, daily filter pack measurements of TIN and TIA were made as part of the EMEP network from 1989 to 2000 (EMEP, 2017a). Following installation of the DELTA system in September 1999, both methods were operated in parallel for 14 months at Eskdalemuir, allowing a comparison to be made of TIN and TIA from both systems. Comparison results are shown in Fig. 4 of parallel data from the AGANet (sum of $\mathrm{HNO}_{3}$ and $\mathrm{NO}_{3}^{-}$) and NAMN (sum of $\mathrm{NH}_{3}$ and $\mathrm{NH}_{4}^{+}$), demonstrating close agreement between the two independent measurements. The EMEP values shown are daily measurements of TIN and TIA averaged to corresponding monthly 

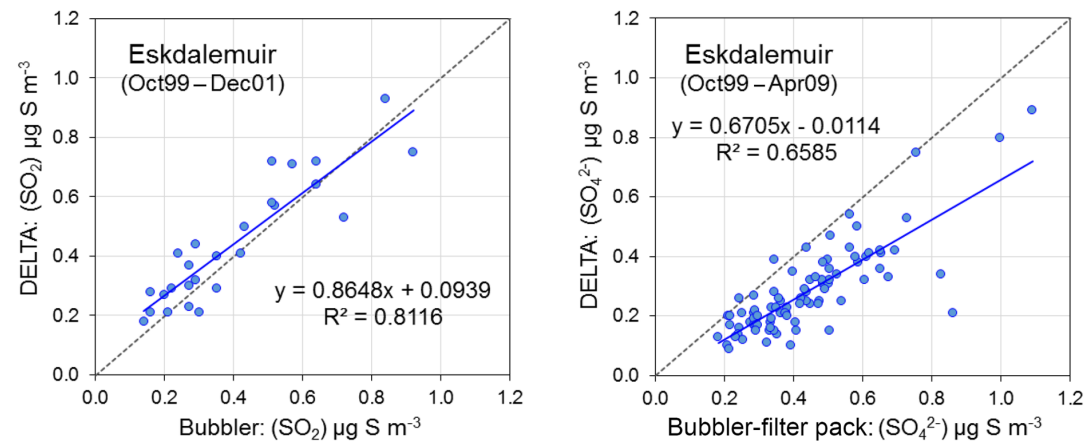

\begin{tabular}{|c|c|c|c|c|}
\hline & AGANet DELTA: $\mathrm{SO}_{2}$ & Bubbler: $\mathrm{SO}_{2}$ & AGANet DELTA: $\mathrm{SO}_{4}{ }^{2-}$ & Filter pack: $\mathrm{SO}_{4}{ }^{2}$ \\
\hline Linear regression: $R^{2}$ & \multicolumn{2}{|l|}{$0.812^{\star \star \star}$} & \multicolumn{2}{|l|}{$0.658^{\star \star \star}$} \\
\hline Slope & \multicolumn{2}{|l|}{$0.865^{n s}$} & \multicolumn{2}{|l|}{$0.670^{* * *}$} \\
\hline Intercept & \multicolumn{2}{|l|}{$0.094^{*}$} & \multicolumn{2}{|l|}{$0.011^{n s}$} \\
\hline Mean $\left(\mu \mathrm{g} \mathrm{S} \mathrm{m}^{-3}\right)$ & 0.44 & 0.40 & 0.28 & 0.44 \\
\hline No. of observations $(n)$ & 26 & 26 & 87 & 87 \\
\hline
\end{tabular}

Significance level (slope different from 1, intercept $=0$ ): * $p<0.05$, ** $p<0.01$, *** $p<0.001 . n s=$ not significant $(p>0.05)$

Figure 5. Comparison of gaseous $\mathrm{SO}_{2}$ and particulate $\mathrm{SO}_{4}^{2-}$ concentrations at the Eskdalemuir monitoring station (EMEP station code $=$ GB0002R; UK-AIR ID = UKA00130) measured under the Acid Deposition Monitoring Program (ADMN, Hayman et al., 2007) with the corresponding gas and aerosol from the UK Acid Gases and Aerosol network (AGANet). ADMN values (EMEP, 2017b) are means of daily measurements for $\mathrm{SO}_{2}$ by the bubbler method and $\mathrm{SO}_{4}^{2-}$ by the EMEP filter pack method (Hayman et al., 2007), matched to the AGANet sampling periods (monthly). Bubbler and filter pack measurements at Eskdalemuir terminated in December 2001 and April 2009 , respectively. A summary of the regression analyses is provided in the table below the graphs.

means for comparison with the DELTA data. For TIN, the regression between EMEP TIN and AGANet (sum of uncorrected $\mathrm{HNO}_{3}+\mathrm{NO}_{3}^{-}$) is close to unity (slope $=0.984, R^{2}=$ $0.94)$, which provided independent verification and support of the DELTA $\mathrm{HNO}_{3}$ measurements at the start of the network. After applying a bias adjustment factor of 0.45 to the $\mathrm{HNO}_{3}$ data (see Sect. 2.6), the AGANet values (sum of corrected $\mathrm{HNO}_{3}+\mathrm{NO}_{3}^{-}$) are smaller than the EMEP TIN (slope $=0.835, R^{2}=0.95$ ). It is possible however, that the filter pack method may also be subject to similar artefacts in $\mathrm{HNO}_{3}$ determination due to co-collection of other oxidized nitrogen species (Tang et al., 2015).

\subsubsection{Comparisons with bubbler and filter pack measurements: $\mathrm{SO}_{2}$ and $\mathrm{SO}_{4}^{2-}$}

Independent measurements of $\mathrm{SO}_{2}$ and $\mathrm{SO}_{4}^{2-}$ with a daily bubbler and filter pack method, respectively, are also available for comparison with the DELTA method at the Eskdalemuir site. Daily $\mathrm{SO}_{2}$ data with a bubbler method (Hayman, 2005) from December 1977 to December 2001 and daily $\mathrm{SO}_{4}^{2-}$ data with an EMEP filter pack method from December 1977 to April 2009 (Hayman, 2006) were downloaded from the EMEP website (EMEP, 2017b). A close agreement is found between the bubbler and DELTA method for $\mathrm{SO}_{2}$ (slope $=0.86, R^{2}=0.82$ ), while there is more scatter between the filter pack and DELTA method for $\mathrm{SO}_{4}^{2-}$ (slope $=0.67, R^{2}=0.66$ ) (Fig. 5). Concentrations of $\mathrm{SO}_{2}$ for the 26 month overlap period were comparable (mean of bubbler method $=0.40 \mu \mathrm{g} \mathrm{S} \mathrm{m}^{-3} \mathrm{cf}$ mean of DELTA method $=0.44 \mu \mathrm{g} \mathrm{S} \mathrm{m}^{-3}$ ), whereas the filter pack $\mathrm{SO}_{4}^{2-}$ concentration (mean $=0.44 \mu \mathrm{g} \mathrm{S} \mathrm{m}^{-3}, n=87$ ) is larger than the corresponding monthly DELTA measurement (mean $=0.28 \mu \mathrm{g} \mathrm{S} \mathrm{m}^{-3}, n=87$ ) (Fig. 5). An earlier detailed assessment of the DELTA system against filter pack with a focus on $\mathrm{SO}_{2}$ and $\mathrm{SO}_{4}^{2-}$ in 1999 by Hayman et al. (2006) had shown close agreement between the methods. It is therefore unclear why the DELTA gives a reading lower than the filter pack $\mathrm{SO}_{4}^{2-}$ at Eskdalemuir in this assessment, since the dataset was a continuation of the original inter-comparison. Possible explanations include uncertainties associated with limit of detection of the daily filter pack method at the very low concentrations encountered at this site, or the sampling of coarser particles by this method (due to high flow rate and open-face sampling) with higher concentrations of sea salt sulfate. The DELTA methodology was unchanged for the duration of the AGANet dataset (1999-2015) in this manuscript, which allows a consistent assessment of overall trends in the $\mathrm{SO}_{4}^{2-}$ data.

\subsection{AGANet data}

Annual data from the AGANet (and also from the NAMN) are submitted to the Department for Environment, Food \& Rural Affairs (Defra) UK-AIR database (https://ukair.defra.gov.uk/, last access: 17 March 2017), in a format consistent with other UK Authority air quality networks and relevant reporting requirements. Every concentration value is labelled with a validity flag and an EMEP flag (see http://www.nilu.no/projects/ccc/flags/index.html, 
last access: 23 March 2017). Ratified calendar year data are published from around June the year following collection. Currently, work is also in progress for the data to be made available from the EMEP database (http://ebas.nilu.no/, last access: 23 March 2017). All data used in this paper (up to 2015), except where specified, are accessed from the UKAIR website (Tang et al., 2017a, b).

\subsection{Uncertainties in $\mathrm{HNO}_{3}$ determination}

$\mathrm{HNO}_{3}$ data were corrected for sampling artefacts in the DELTA method with an empirical correction factor of 0.45 (see Sect. 2.6). Interferences in $\mathrm{HNO}_{3}$ determination arise through the simultaneous collection of reactive oxidized nitrogen species on the $\mathrm{K}_{2} \mathrm{CO}_{3}$ coating that forms nitrate ions in the aqueous extracts of exposed denuders. Potential interfering species include $\mathrm{HONO}, \mathrm{NO}_{2}, \mathrm{~N}_{2} \mathrm{O}_{5}$ and PAN, as well as other inorganic and organic nitrogen species. HONO is most likely to contribute to the interference, since it is collected effectively on a carbonate coating and concentrations of HONO have been reported to be comparable to, and in some places exceed $\mathrm{HNO}_{3}$ in the UK (e.g. Kitto and Harrison, 1992; Conolly et al., 2016). Interference from $\mathrm{NO}_{2}$ on the other hand should be small, since the reactivity of a carbonate coating surface towards $\mathrm{NO}_{2}$ is low (Allegrini et al., 1987), with capture of $\mathrm{NO}_{2}$ on carbonate ranging from $0.5 \%$ to $5 \%$ (Allegrini et al., 1987; Fitz, 2002) and their concentrations are also small at rural AGANet sites $\left(<10 \mu \mathrm{g} \mathrm{NO}_{2} \mathrm{~m}^{-3}\right.$; Conolly et al., 2016). Tests by Steinle (2009) on the DELTA $\mathrm{K}_{2} \mathrm{CO}_{3} /$ glycerol coated denuders also confirmed low capture (ca. $3 \%$ ) of $\mathrm{NO}_{2}$.

The correction factor was derived from two years of field intercomparison measurements at five sites across a range of pollutant concentrations across the UK, from a clean rural background site in southern Scotland (Auchencorth) to a polluted urban site (London, Cromwell road) in southern England (Tang et al., 2015). It is recognized that the correction factor to derive the "real $\mathrm{HNO}_{3}$ " signal from the carbonate coated denuders will also be dependent on the relative concentrations of $\mathrm{HNO}_{3}$ to interfering species present in the atmosphere and likely to be both site and season specific. The 2 years of data indeed show this variability between sites and between seasons. Given the complexities of atmospheric chemistry of the large family of oxidized nitrogen species, further work is clearly needed to understand what the carbonate denuders are measuring, before an improved correction algorithm for the $\mathrm{HNO}_{3}$ data can be developed with any confidence.

The empirical $0.45 \mathrm{HNO}_{3}$ correction factor is therefore at present a best estimate across a range of pollutant concentrations and seasons encountered in the UK, based on available test data from 5 sites. At the cleanest rural sites (e.g. Eskdalemuir), where a much smaller $\mathrm{HONO}$ and $\mathrm{NO}_{2}$ interference of the DELTA $\mathrm{HNO}_{3}$ signal is expected, the $\mathrm{HNO}_{3}$ concentrations may be under-estimated after correction. This may partly explain the slope deviating from unity in the comparison of corrected DELTA TIN with EMEP filter pack TIN data (slope $=0.835, R^{2}=0.95$ ) at Eskdalemuir (see Sect. 3.1.2). Conversely, at more polluted sites such as London that are affected by a larger interference from $\mathrm{HONO}$ and $\mathrm{NO}_{2}$, the $\mathrm{HNO}_{3}$ determination may be over-estimated after correction. Apart from two urban sites (London and Edinburgh), all other sites in the AGANet are rural, located away from traffic, and the 0.45 correction factor should be more representative.

Since January 2016, the DELTA denuder sample train configuration in AGANet was changed to two $\mathrm{NaCl}$ coated denuders (selective for $\mathrm{HNO}_{3}$, e.g. Allegrini et al., 1987), with a third $\mathrm{K}_{2} \mathrm{CO}_{3} /$ glycerol coated denuder to collect $\mathrm{SO}_{2}$. At three sites (Auchencorth, Bush OTC and Stoke Ferry), parallel measurements of the old configuration (two $\mathrm{K}_{2} \mathrm{CO}_{3} /$ glycerol coated denuders) and new configuration (two $\mathrm{NaCl}$ coated denuders $+\mathrm{K}_{2} \mathrm{CO}_{3} /$ glycerol coated denuder) were conducted over 12 months in 2016. In the new configuration, nitrates measured on the $\mathrm{NaCl}$ denuders are reported as $\mathrm{HNO}_{3}$, whereas nitrate on the $\mathrm{K}_{2} \mathrm{CO}_{3}$ denuder are assumed to come from other oxidized nitrogen species and are not reported. Comparing the sum of nitrate concentrations from the new $\left(2 \times \mathrm{NaCl}+1 \times \mathrm{K}_{2} \mathrm{CO}_{3}\right)$ with the old $\left(2 \times \mathrm{K}_{2} \mathrm{CO}_{3}\right)$ configurations indicated matching capture of total nitrate by the two parallel systems (new/old nitrate ratio $=0.95)$. A comparison of nitrate concentrations on the $2 \times \mathrm{NaCl}$ denuders only (new configuration) with the $2 \times \mathrm{K}_{2} \mathrm{CO}_{3}$ denuders (old configuration) yielded an average ratio of 0.42 , lending further support to the 0.45 empirical factor. Additionally, the new sample train configuration is providing an extensive dataset which will allow the magnitude of $\mathrm{HNO}_{3}$ interference at each site to be quantified, by comparing the amount of nitrate measured on the $2 \times \mathrm{NaCl}$ and $\mathrm{K}_{2} \mathrm{CO}_{3}$ coated denuders. Initial analysis of 2016 data (unpublished data) showed that the mean ratio of nitrate on $\mathrm{NaCl}: \mathrm{K}_{2} \mathrm{CO}_{3}$ of all sites was 0.44 , ranging from 0.31 (Bush OTC) to 0.59 (Moorhouse). Seasonally, the average monthly ratio (taken as the mean across all sites for each month) was lowest in winter (0.25 in December and 0.27 in January) and highest between May to June $(0.59,0.56$ and 0.57$)$. It may therefore be possible to derive an improved correction algorithm that is both site and season specific, and work is ongoing to make this assessment. A detailed assessment of sampling artefacts and uncertainties in the DELTA method and the effects of a method change in the AGANet forms the subject of a next paper that is currently in preparation.

\subsection{Spatial patterns in relation to pollutant sources and transport}

In Fig. 6, the spatial patterns for each of the gas and aerosol components measured are shown in the annual maps for the example year 2013. A gradient in the concentrations of acid gases $\mathrm{HNO}_{3}$ and $\mathrm{SO}_{2}$, and related aerosols $\mathrm{NO}_{3}^{-}$and 
$\mathrm{SO}_{4}^{2-}$ can be seen across the UK, highest in the south and east (combustion or vehicular sources and long-range transboundary pollutant transport from Europe) and lowest in the north and west of the UK (fewer sources, furthest from influence of Europe). The ranges in site-annual mean concentrations $\left(\mu \mathrm{g}\right.$ molecule $\left.\mathrm{m}^{-3}\right)$ in 2013 for the gases were as follows: $\mathrm{HNO}_{3}: 0.12-1.2 ; \mathrm{HCl}: 0.15-0.52 ; \mathrm{SO}_{2}: 0.10-$ 1.08 , while those for aerosol were as follows: $\mathrm{NO}_{3}^{-}: 0.33-$ 3.1; $\mathrm{Cl}^{-}: 0.54-3.3 ; \mathrm{SO}_{4}^{2-}: 0.35-1.2 ; \mathrm{Na}^{+}: 0.35-1.8 ; \mathrm{Ca}^{2+}$ : $<$ lod-0.11; $\mathrm{Mg}^{2+}$ : 0.03-0.19.

The largest $\mathrm{HNO}_{3}$ concentrations were measured at the London Cromwell site (2013 site annual mean $=1.3 \mu \mathrm{g} \mathrm{HNO}_{3} \mathrm{~m}^{-3}$ cf. 2013 mean of 30 sites $=0.40 \mu \mathrm{gNO}_{3} \mathrm{~m}^{-3}$ ). London and Edinburgh are the only two urban sites in the AGANet, with the other 28 sites all in rural environments. $\mathrm{HNO}_{3}$ concentrations in Edinburgh, the capital of Scotland with a population that is 18 times smaller than London ( 0.5 million vs. 8.8 million), is about 2 times lower than London, but larger than the national average (2013 annual mean $=0.58 \mu \mathrm{g} \mathrm{HNO}_{3} \mathrm{~m}^{-3}$ ). For $\mathrm{SO}_{2}$, the highest concentrations were recorded at Sutton Bonington due to close proximity to the 2000 MW capacity coal-fired Ratcliffe-on-Soar power station ( $2 \mathrm{~km}$ North). A peak monthly concentration of $10.9 \mu \mathrm{gSO}_{2} \mathrm{~m}^{-3}$ was recorded in May 2000 at this site, with an annual mean concentration of $5.9 \mu \mathrm{g} \mathrm{SO}_{2} \mathrm{~m}^{-3}$ for that year that was also 3 times higher than the national average (mean of 12 sites $=1.9 \mathrm{SO}_{2} \mathrm{~m}^{-3}$ cf. mean of 11 sites (excl. Sutton Bonington $=1.5 \mathrm{SO}_{2} \mathrm{~m}^{-3}$ ). At remote sites further away from sources, concentrations of $\mathrm{HNO}_{3}$ and $\mathrm{SO}_{2}$ are smaller, e.g. Lough Navar in Northern Ireland (2013 annual mean: $0.15 \mu \mathrm{g} \mathrm{HNO}_{3} \mathrm{~m}^{-3}$ and $0.21 \mu \mathrm{gSO}_{2} \mathrm{~m}^{-3}$ ) and Strathvaich Dam in north-western Scotland (2013 annual mean $=0.17 \mu \mathrm{g} \mathrm{HNO}_{3} \mathrm{~m}^{-3}$ and $0.18 \mu \mathrm{g} \mathrm{SO}_{2} \mathrm{~m}^{-3}$ ). $\mathrm{NO}_{3}^{-}$and $\mathrm{SO}_{4}^{2-}$ as secondary aerosols have longer residence times in the atmosphere and are expected to be more spatially homogeneous than their precursor gases. The spatial distribution in concentrations of particulate $\mathrm{NO}_{3}^{-}\left(0.33-3.1 \mu \mathrm{g} \mathrm{m}^{-3}\right)$ and $\mathrm{SO}_{4}^{2-}\left(0.35-1.2 \mu \mathrm{g} \mathrm{m}^{-3}\right)$ are however similar to that of $\mathrm{HNO}_{3}\left(0.12-1.3 \mu \mathrm{g} \mathrm{m}^{-3}\right)$ and $\mathrm{SO}_{2}\left(0.10-1.1 \mu \mathrm{g} \mathrm{m}^{-3}\right)$, with no clear differences in the main regional patterns from only 30 sites.

$\mathrm{HCl}$ are mostly emitted from coal combustion and the highest concentrations are in the source areas in the southeast and south-west, and also in central England (north of Ratcliffe-on-Soar power station). There is also a marine source for $\mathrm{HCl}$ formed by the reaction of sea salt with $\mathrm{HNO}_{3}$ and $\mathrm{H}_{2} \mathrm{SO}_{4}$ (Roth and Okada, 1998; Ianniello et al., 2011) that may contribute to additional enhancement of local to regional $\mathrm{HCl}$ concentrations. The spatial distributions of $\mathrm{Cl}^{-}$ and $\mathrm{Na}^{+}$were similar, with largest concentrations at the coastal sites Goonhilly in south-western England and Lerwick Shetland in the Shetland Isles, highlighting the importance of marine sources to the sea salt $(\mathrm{NaCl})$ aerosol. Fur- ther away from the coast and influence of marine aerosol, the smallest concentrations of $\mathrm{Cl}^{-}$and $\mathrm{Na}^{+}$are measured in the west of the country (Lough Navar in Northern Ireland and Cwmystwyth in mid-Wales) and most of Scotland (with the exception of Shetland). $\mathrm{Mg}^{2+}$ is also seen to show a similar spatial distribution to $\mathrm{Na}^{+}$and $\mathrm{Cl}^{-}$, which suggests that it may be in the form of $\mathrm{MgCl}_{2}$, although the range of concentrations at sites are small $\left(0.03-0.19 \mu \mathrm{g} \mathrm{m}^{-3}\right)$. There is however no clear spatial pattern for $\mathrm{Ca}^{2+}$, but since concentrations are mostly at or below LOD, any assessment of this component is highly uncertain.

In the case of $\mathrm{NH}_{3}$, the extensive spatial heterogeneity seen is related to large variation in emission sources at ground level across the UK (Tang et al., 2018). Aerosol $\mathrm{NH}_{4}^{+}$, as expected for a secondary component, show a less variable concentration field. The spatial distribution of $\mathrm{NH}_{4}^{+}$is similar to $\mathrm{SO}_{4}^{2-}$ and $\mathrm{NO}_{3}^{-}$over the UK (Fig. 6), due to the close coupling between species from the formation of particle phase $\left(\mathrm{NH}_{4}\right)_{2} \mathrm{SO}_{4}$ and $\mathrm{NH}_{4} \mathrm{NO}_{3}$ (see next section).

\subsection{Correlations between gas and aerosol species}

Correlations plots between the gas and aerosol phases of the different components are shown in Fig. 7, with a summary of the regression results provided in Table 2. The comparison of gas phase concentrations show that gaseous $\mathrm{NH}_{3}$ is poorly correlated with either $\mathrm{SO}_{2}$ or $\mathrm{HNO}_{3}$, as might be expected since the emission sources of these pollutants are different. In the case of the acid gases however, the significant correlations between $\mathrm{HNO}_{3}: \mathrm{SO}_{2}\left(R^{2}=0.35\right), \mathrm{HNO}_{3}: \mathrm{HCl}\left(R^{2}=\right.$ $0.25)$, and $\mathrm{SO}_{2}: \mathrm{HCl}\left(R^{2}=0.21\right)$ may be related to similarity in the regional distribution of their emissions. These comparisons show that there is on average 5 times more $\mathrm{NH}_{3}$ than $\mathrm{SO}_{2}$ and 13 times more $\mathrm{NH}_{3}$ than $\mathrm{HNO}_{3}$ at the AGANet sites (on a molar basis), and that $\mathrm{SO}_{2}$ concentration is nearly 3 times larger than $\mathrm{HNO}_{3}$ (on a molar basis).

In the aerosol components, there is very high correlation between $\mathrm{NO}_{3}^{-}, \mathrm{SO}_{4}^{2-}$, and $\mathrm{NH}_{4}^{+}$, and between $\mathrm{Na}^{+}$and $\mathrm{Cl}^{-}$, but no discernible relationship between $\mathrm{NH}_{4}^{+}$and $\mathrm{Cl}^{-}$ (Fig. 7). The near $1: 1$ relationship in the scatter plot of the sum of $\mathrm{NO}_{3}^{-}$and $\mathrm{SO}_{4}^{2-}$ (neq $\mathrm{m}^{-3}$ ) vs. $\mathrm{NH}_{4}^{+}\left(\right.$neq $\left.\mathrm{m}^{-3}\right)$ (slope $=0.91, R^{2}=0.93$ ), in the absence of any correlation between $\mathrm{NH}_{4}^{+}$and $\mathrm{Cl}^{-}$, suggests that $\mathrm{H}_{2} \mathrm{SO}_{4}$ and $\mathrm{HNO}_{3}$ in the atmosphere are fully neutralized by $\mathrm{NH}_{3}$ to form $\left(\mathrm{NH}_{4}\right)_{2} \mathrm{SO}_{4}, \mathrm{NH}_{4} \mathrm{HSO}_{4}$ and $\mathrm{NH}_{4} \mathrm{NO}_{3}$ (Aneja et al., 2001). For $\mathrm{Cl}^{-}$, the high correlation with $\mathrm{Na}^{+}$(slope $=1.04, R^{2}=$ 0.8 ) lends support that the $\mathrm{Cl}^{-}$measured in the DELTA are derived mainly from sea salt $(\mathrm{NaCl})$. Similar to the relative concentrations of gases, $\mathrm{NH}_{4}^{+}$concentrations (on a molar basis) are larger than $\mathrm{SO}_{4}^{2-}$ and $\mathrm{NO}_{3}^{-}$, but $\mathrm{NO}_{3}^{-}$is in molar excess over $\mathrm{SO}_{4}^{2-}$. The correlations between $\mathrm{NH}_{4}^{+}$and sum $\left(\mathrm{NO}_{3}^{-}+2 \times \mathrm{SO}_{4}^{2-}\right)$, and for $\mathrm{Na}^{+}$and $\mathrm{Cl}^{-}$forms the basis of ion balance checks in data quality assessment, as discussed in Sect. 2.5 and shows that robust data are obtained. 


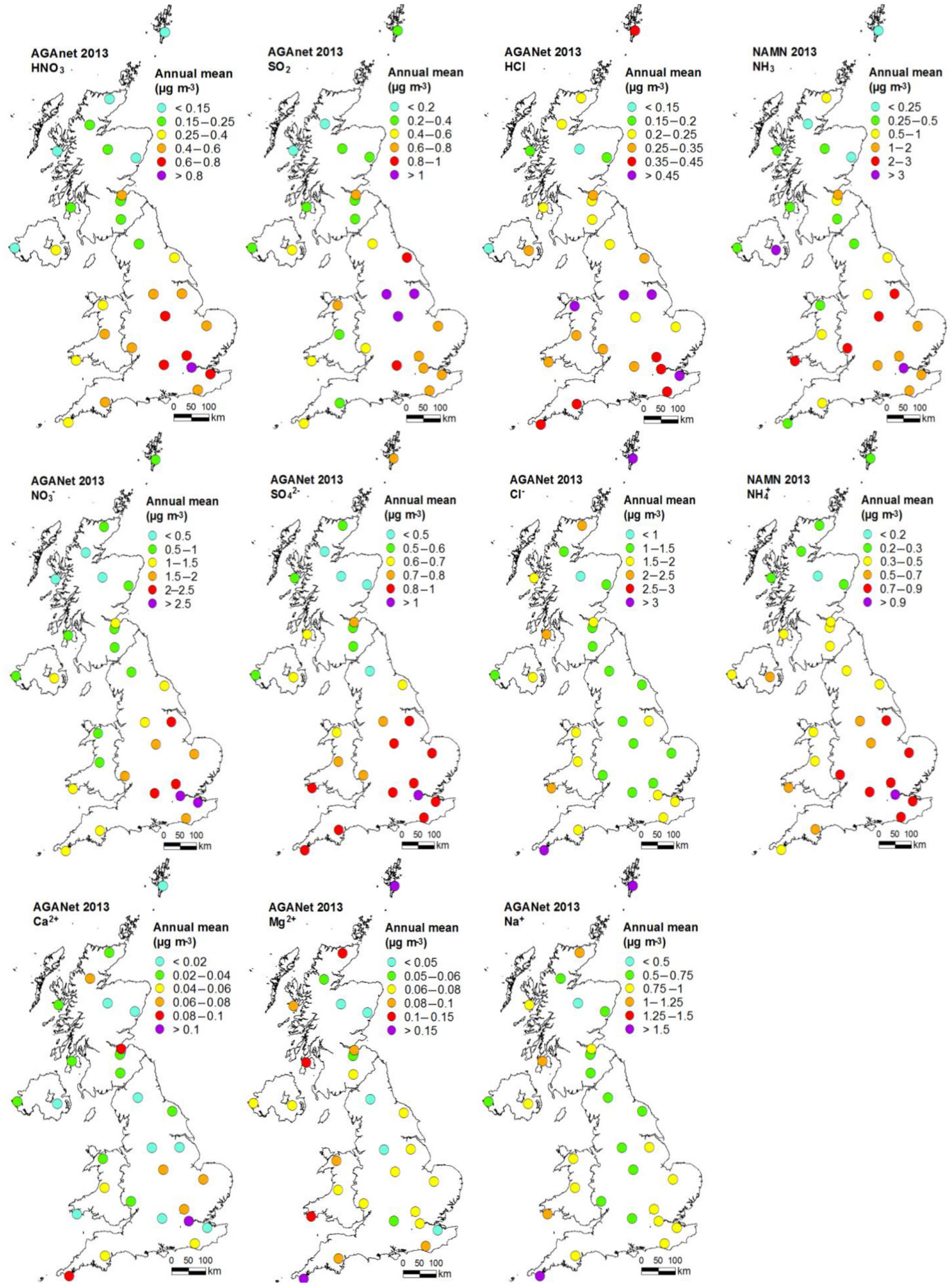

Figure 6. Annual mean monitored acid gas $\left(\mathrm{HNO}_{3}, \mathrm{SO}_{2}, \mathrm{HCl}\right)$ and aerosol $\left(\mathrm{NO}_{3}^{-}, \mathrm{SO}_{4}^{2-}, \mathrm{Cl}^{-}, \mathrm{Na}^{+}, \mathrm{Ca}^{2+}, \mathrm{Mg}^{2+}\right)$ concentrations from the UK Acid Gas and Aerosol Monitoring Network (AGANet) across the UK from annual averaged monthly measurements made in 2013. $\mathrm{NH}_{3}$ and $\mathrm{NH}_{4}^{+}$measured at the same time from the UK National Ammonia Monitoring Network (NAMN, Tang et al., 2018) are also shown alongside for comparison. 
Table 2. Correlation coefficients $\left(R^{2}\right)$ for different species across the 30 measurement sites.

\begin{tabular}{lllllllll}
\hline & $\mathrm{HNO}_{3}$ & $\mathrm{HCl}$ & $\mathrm{SO}_{2}$ & $\mathrm{NO}_{3}^{-}$ & $\mathrm{Cl}^{-}$ & $\mathrm{SO}_{4}^{2-}$ & $\mathrm{NH}_{4}^{+}$ & $\mathrm{Na}^{+}$ \\
\hline $\mathrm{HNO}_{3}$ & 1.00 & $0.25^{* * *}$ & $0.39^{* * *}$ & $0.45^{* * *}$ & $0.07^{* * *}$ & $0.54^{* * *}$ & $0.49^{* * *}$ & $0.02^{*}$ \\
$\mathrm{HCl}$ & - & 1.00 & $0.21^{* * *}$ & $0.14^{* * *}$ & $0.01^{\mathrm{ns}}$ & $0.24^{* * *}$ & $0.19^{* * *}$ & $0.04^{* *}$ \\
$\mathrm{SO}_{2}$ & - & - & 1.00 & $0.30^{* * *}$ & $0.00^{\mathrm{ns}}$ & $0.47^{* * *}$ & $0.37^{* * *}$ & $0.01^{\mathrm{ns}}$ \\
$\mathrm{NO}_{3}^{-}$ & - & - & - & 1.00 & $0.00^{\mathrm{ns}}$ & $0.61^{* * *}$ & $0.90^{* * *}$ & $0.02^{\mathrm{ns}}$ \\
$\mathrm{Cl}^{-}$ & - & - & - & - & 1.00 & $0.04^{* *}$ & $0.01^{\mathrm{ns}}$ & $0.79^{* * *}$ \\
$\mathrm{SO}_{4}^{2-}$ & - & - & - & - & - & 1.00 & $0.73^{* * *}$ & $0.00^{\mathrm{ns}}$ \\
$\mathrm{NH}_{4}^{+}$ & - & - & - & - & - & - & 1.00 & $0.00^{\mathrm{ns}}$ \\
$\mathrm{Na}^{+}$ & - & - & - & - & - & - & - & 1.00 \\
\hline
\end{tabular}

Significance level: ${ }^{*} p<0.05,{ }^{* *} p<0.01,{ }^{* * *} p<0.001 . \mathrm{ns}=$ not significant $(p>0.05)$.

Sea salt aerosol, derived from sea spray, has essentially the same composition as seawater (Keene et al., 1986). The marine aerosol comprises two distinct aerosol types: (1) primary sea salt aerosol produced by the mechanical disruption of the ocean surface and (2) secondary aerosol, primarily in the form of non-sea salt (nss) sulfate and organic species, formed by gas-to-particle conversion processes such as binary homogeneous nucleation, heterogeneous nucleation and condensation (O'Dowd and Leeuw, 2007). It has been shown that the ratio of the mass concentrations of $\mathrm{SO}_{4}^{2-}$ and $\mathrm{Cl}^{-}$to the reference $\mathrm{Na}^{+}$species in seawater may be used to estimate mass concentrations of non-sea salt $\mathrm{SO}_{4}^{2-}\left(\mathrm{nss}_{-} \mathrm{SO}_{4}\right)$ and non-sea salt $\mathrm{Cl}^{-}$(nss_Cl) in aerosol, according to Eqs. (4) and (5), respectively (Keene et al., 1986; O'Dowd and de Leeuw, 2007).

$\left[\right.$ nss_SO $\left.\mathrm{SO}_{4}\right]=\left[\mathrm{SO}_{4}^{2-}\right]-\left(0.25 \times\left[\mathrm{Na}^{+}\right]\right)$

$\left[\mathrm{nss} \_\mathrm{Cl}\right]=\left[\mathrm{Cl}^{-}\right]-\left(1.80 \times\left[\mathrm{Na}^{+}\right]\right)$

Applying Eq. (4) to the $\mathrm{SO}_{4}^{2-}$ data in Fig. 7, nss_SO $\mathrm{SO}_{4}$ is estimated to comprise on average $25 \%$ (range $=3 \%$ $83 \%, n=187$ ) of the measured total $\mathrm{SO}_{4}^{2-}$ aerosol. Regression of nss_SO $\mathrm{SO}_{4}$ vs. $\mathrm{NH}_{4}^{+}$(slope $=0.18$, intercept $=0.47$, $R^{2}=0.71$ ) (Fig. S3) was not significantly different from the regression of total $\mathrm{SO}_{4}^{2-}$ vs. $\mathrm{NH}_{4}^{+}$(slope $=0.18$, intercept $=2.4, R^{2}=0.73$ ) (Fig. 7). Sources of nss_SO $S_{4}$ are (i) biological oxidation of dimethylsulfide and (ii) oxidation of $\mathrm{SO}_{2}$ (O'Dowd and de Leeuw, 2007). This analysis demonstrates that sea salt $\mathrm{SO}_{4}^{2-}$ aerosol makes up a significant and variable fraction of the total $\mathrm{SO}_{4}^{2-}$ measured, consistent with observations of the contribution by sea salt $\mathrm{SO}_{4}^{2-}$ to the total $\mathrm{SO}_{4}^{2-}$ in precipitation in the UK (ROTAP, 2012). The improved intercept from the nss_SO $\mathrm{SO}_{4}$ regression (Fig. S3) suggests that nss_SO $\mathrm{SO}_{4}$ are mainly associated with $\mathrm{NH}_{4}^{+}$.

Estimated nss_Cl concentrations according to Eq. (4) was however negligible (mean $=-0.09 \mu \mathrm{g} \mathrm{m}^{-3}, n=188$ ), compared to the total $\mathrm{Cl}^{-}\left(\right.$mean $\left.=1.3 \mu \mathrm{g} \mathrm{m}^{-3}, n=188\right)$. Studies have shown that part of the chloride of sea salt can be substituted by $\mathrm{SO}_{4}^{2-}$ and $\mathrm{NO}_{3}^{-}$through a reaction with $\mathrm{H}_{2} \mathrm{SO}_{4}$ and $\mathrm{HNO}_{3}$, known as the $\mathrm{Cl}^{-}$deficit (Ayers et al., 1999). The close coupling between $\mathrm{Cl}^{-}$and $\mathrm{Na}^{+}$(near $1: 1$ relationship) presented here suggests that the measured $\mathrm{Cl}^{-}$in the aerosol are mostly sea salt in origin, with no evidence of depletion of $\mathrm{Cl}^{-}$from sea salt aerosols.

\subsection{Seasonal variation in acid gases and aerosols}

The average seasonal cycles for all gas and aerosol components derived from the mean of monthly data of all sites for the period 2000 to 2015 are compared in Fig. 8. Clear differences are observed in these seasonal cycles, influenced by local to regional emissions, climate, meteorology and photochemical processes.

$\mathrm{HNO}_{3}$ is a secondary product of $\mathrm{NO}_{x}$, but $\mathrm{NO}_{x}$ emissions are dominated by vehicular sources which are not expected to show large seasonal variations. Seasonal changes in chemistry and meteorology are therefore more likely to be a source of the observed variations in $\mathrm{HNO}_{3}$ and $\mathrm{NO}_{3}^{-}$(Fig. 8). A weak seasonal cycle is observed in $\mathrm{HNO}_{3}$, with slightly higher concentrations in late winter and early spring that may be attributed to photochemical processes with elevated ozone in spring (AQEG, 2009) leading to formation of $\mathrm{HNO}_{3}$ during this period (Pope et al., 2016). As discussed in Sect. 3.3, a constant correction factor was applied to all $\mathrm{HNO}_{3}$ data, which does not take into account seasonal dependency. The concentrations in $\mathrm{HNO}_{3}$ may therefore be over-estimated in winter (less $\mathrm{HNO}_{3}$ formed from photochemical processes) and under-estimated in summer (larger $\mathrm{HNO}_{3}$ concentrations due to increased $\cdot \mathrm{OH}$ radicals for reaction with $\mathrm{NO}_{2}$ to form $\mathrm{HNO}_{3}$ ), masking the true extent in the seasonal profile.

In contrast, the seasonal cycle for particulate $\mathrm{NO}_{3}^{-}$is more distinct with a large peak in concentrations that occur every spring, together with a second smaller peak in autumn (Fig. 8). $\mathrm{NH}_{3}$, the main neutralizing gas in the atmosphere that reacts with $\mathrm{HNO}_{3}$ to form $\mathrm{NH}_{4} \mathrm{NO}_{3}$, has a correspondingly large peak in concentration in spring, a second smaller peak in autumn, but with elevated concentrations in summer and lowest in winter (Fig. 8). Although particulate $\mathrm{NO}_{3}^{-}$formation is dependent upon the availability of $\mathrm{NH}_{3}$ for reaction with $\mathrm{HNO}_{3}$, its concentration is also governed by the equi- 

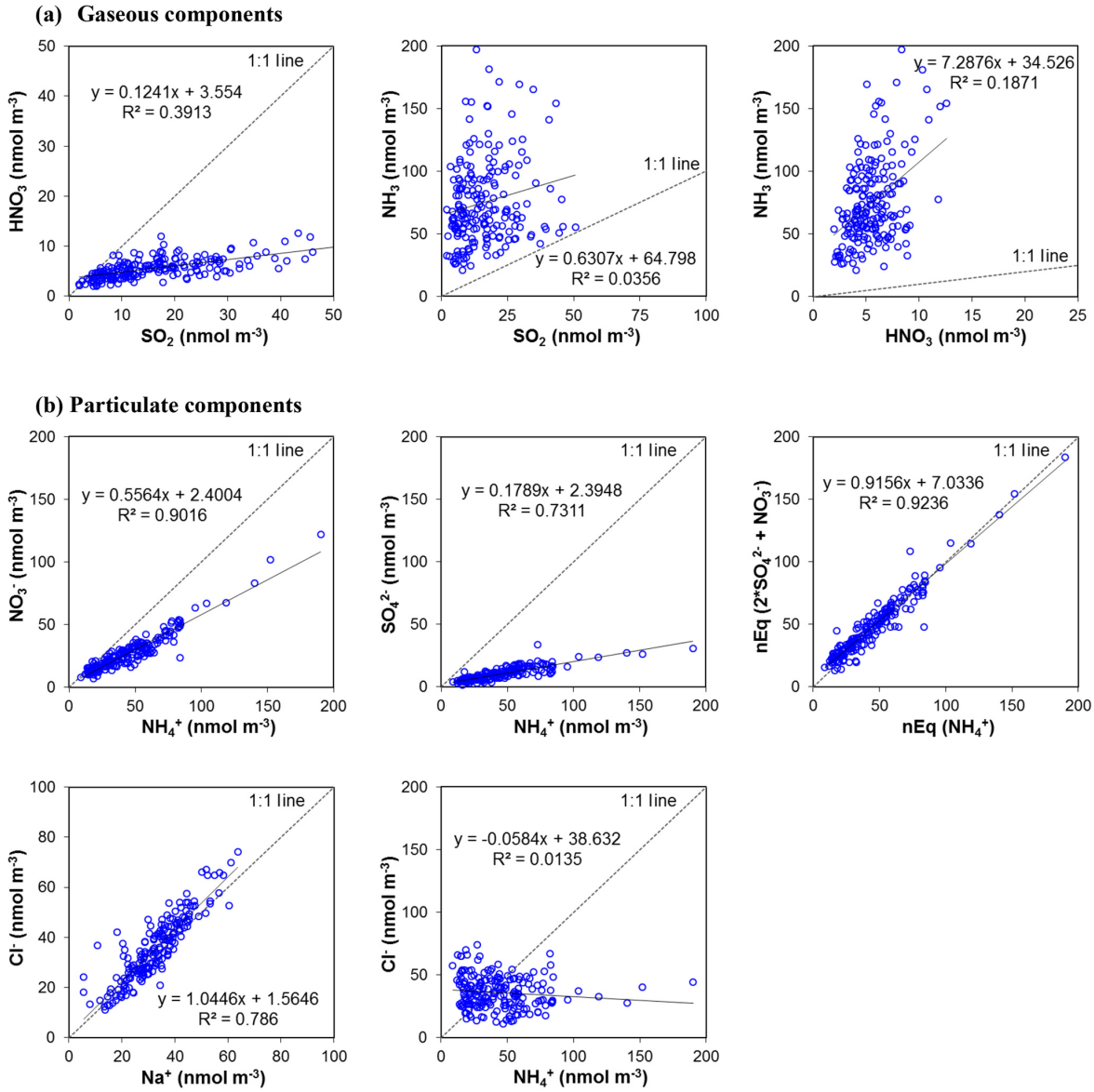

Figure 7. Scatter plots between concentrations of (a) gaseous species $\mathrm{HNO}_{3}, \mathrm{SO}_{2}$, and $\mathrm{NH}_{3}$, and (b) particulate species $\mathrm{NO}_{3}^{-}, \mathrm{SO}_{4}^{2-}, \mathrm{NH}_{4}^{+}$, $\mathrm{Cl}^{-}$, and $\mathrm{Na}^{+}$from mean monthly measurements (1999-2015) from the 12 sites in the UK Acid Gas and Aerosol Monitoring Network (AGANet) that were operational over the whole period. $\mathrm{NH}_{3}$ and $\mathrm{NH}_{4}^{+}$data are from the UK National Ammonia Monitoring Network (NAMN, Tang et al., 2018) made at the same time. Each data point represents a single monthly DELTA measurement.

librium that exists between gaseous $\mathrm{HNO}_{3}, \mathrm{NH}_{3}$, and particulate $\mathrm{NH}_{4} \mathrm{NO}_{3}$, the latter of which is appreciably volatile at ambient temperatures (Stelson and Seinfeld, 1982). Partitioning between the gas and aerosol phase is therefore also a key driver for their atmospheric residence times and concentrations. $\mathrm{HNO}_{3}$ and $\mathrm{NH}_{3}$ that are not removed by deposition may react together in the atmosphere to form $\mathrm{NH}_{4} \mathrm{NO}_{3}$ aerosol, when the concentration product $\left[\mathrm{NH}_{3}\right] \cdot\left[\mathrm{HNO}_{3}\right]$ exceeds equilibrium values. Since $\mathrm{NH}_{4} \mathrm{NO}_{3}$ is semi-volatile, any that is not dry or wet deposited can potentially dissociate to release $\mathrm{NH}_{3}$ and $\mathrm{HNO}_{3}$, effectively increasing their residence times in the atmosphere. The formation and dissociation in turn are strongly influenced by ambient temperature and humidity.

Warm, dry conditions in summer promote dissociation, increasing gas-phase $\mathrm{HNO}_{3}$ relative to particulate-phase $\mathrm{NH}_{4} \mathrm{NO}_{3}$. This process accounts for the minima in $\mathrm{NO}_{3}^{-}$concentrations (Fig. 8) and the highest ratio of $\mathrm{HNO}_{3}$ to $\mathrm{NO}_{3}^{-}$ seen in July (Fig. 9). Cooler conditions in the spring and au- tumn sees a larger fraction of the volatile $\mathrm{NH}_{4} \mathrm{NO}_{3}$ remaining in the aerosol phase. The largest peak in $\mathrm{NO}_{3}^{-}$concentrations (Fig. 8) and the lowest $\mathrm{HNO}_{3}: \mathrm{NO}_{3}^{-}$ratio in springtime (Fig. 9) is thus a combination of increased $\mathrm{NO}_{3}^{-}$formation from reaction between higher concentrations of the precursor gases $\mathrm{HNO}_{3}$ and $\mathrm{NH}_{3}$, and increased partitioning to the aerosol phase in cooler, more humid climate. Import from long-range transboundary transport of particulate $\mathrm{NO}_{3}^{-}$, e.g. from continental Europe into the UK, as discussed in Vieno et al. $(2014,2016)$ adds to the elevated $\mathrm{NO}_{3}^{-}$concentrations. In winter, low temperature and high humidity also shifts the equilibrium to formation of $\mathrm{NH}_{4} \mathrm{NO}_{3}$ from the gas-phase $\mathrm{HNO}_{3}$ and $\mathrm{NH}_{3}$. Since $\mathrm{NH}_{3}$ concentrations are also lowest in winter, with less $\mathrm{NH}_{3}$ available for reaction, $\mathrm{NH}_{4} \mathrm{NO}_{3}$ concentrations are correspondingly smaller in winter than in spring or autumn.

$\mathrm{SO}_{2}$, by contrast, are highest in the winter, with concentrations exceeding summer values on average by a factor of 2 (Fig. 8). Higher emissions of $\mathrm{SO}_{2}$ from combustion pro- 

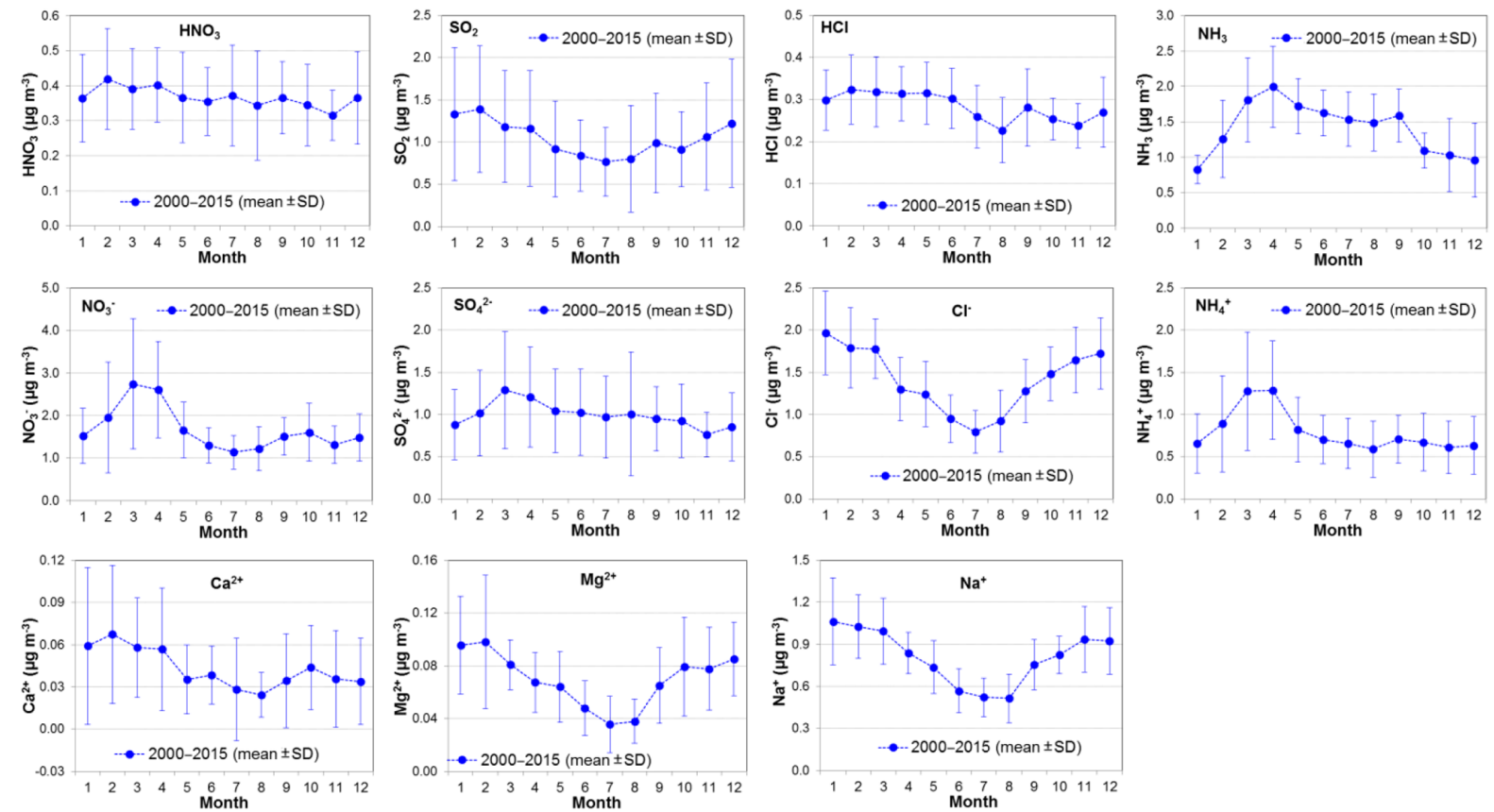

Figure 8. Average annual cycles for $\mathrm{HNO}_{3}, \mathrm{SO}_{2}, \mathrm{HCl}$ and aerosol $\mathrm{NO}_{3}^{-}, \mathrm{SO}_{4}^{2-}, \mathrm{Cl}^{-}, \mathrm{Na}^{+}, \mathrm{Ca}^{2+}$ and $\mathrm{Mg}^{2+}$ from the $\mathrm{UK}^{\mathrm{Acid}} \mathrm{Gases}$ and Aerosol Monitoring Network (AGANet). The $\mathrm{NH}_{3}$ and $\mathrm{NH}_{4}^{+}$concentrations measured at the same time in the UK National Ammonia Monitoring Network (NAMN, Tang et al., 2018) are also shown for comparison. Each data point in the graphs represents the mean \pm SD of monthly measurements of all sites in the network.
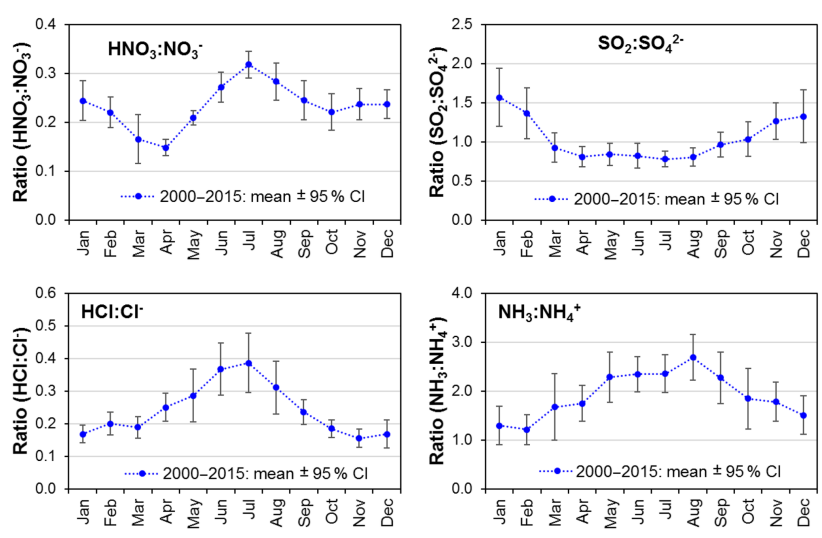

Figure 9. Average annual cycles in the ratios of gas:aerosol component concentrations. $\mathrm{HNO}_{3}, \mathrm{SO}_{2}, \mathrm{HCl}$ and aerosol $\mathrm{NO}_{3}^{-}, \mathrm{SO}_{4}^{2-}$, $\mathrm{Cl}^{-}$data (annual mean, $\mu \mathrm{g} \mathrm{m}^{-3}$ ) are from the UK Acid Gases and Aerosol Monitoring Network (AGANet). $\mathrm{NH}_{3}$ and $\mathrm{NH}_{4}^{+}$data (annual mean, $\mu \mathrm{g} \mathrm{m}^{-3}$ ) that are measured at the same time for the UK National Ammonia Monitoring Network (NAMN, Tang et al., 2018) are also shown for comparison. Each data point in the graphs represents the mean $\pm 95 \%$ confidence interval (CI) of monthly measurements of 12 sites operational in the network over the period 2000 to 2015 . cesses (heating) during the winter months, coupled to stable atmospheric conditions resulting in build-up of concentrations at ground level contributes to the winter maximum. Since the reaction of $\mathrm{SO}_{2}$ with $\mathrm{NH}_{3}$ to form $\left(\mathrm{NH}_{4}\right)_{2} \mathrm{SO}_{4}$ is effectively irreversible (Bower et al., 1997), the ratio of the concentrations of $\mathrm{SO}_{2}$ and $\mathrm{SO}_{4}^{2-}$ (Fig. 9) is largely governed by the availability of $\mathrm{SO}_{2}$ and $\mathrm{NH}_{3}$ to form $\left(\mathrm{NH}_{4}\right)_{2} \mathrm{SO}_{4}$. The temporal profile of $\mathrm{SO}_{4}^{2-}$ has a peak in concentrations in spring, although not as pronounced as the $\mathrm{NO}_{3}^{-}$peak (Fig. 8). This may be attributed to enhanced formation of $\left(\mathrm{NH}_{4}\right)_{2} \mathrm{SO}_{4}$, since peaks in concentrations of $\mathrm{NH}_{3}$ and $\mathrm{NH}_{4}^{+}$also occur in spring (Fig. 8) and from the import of particulates from longrange transboundary transport. Unlike $\mathrm{SO}_{2}$, aerosol $\mathrm{SO}_{4}^{2-}$ concentrations are higher in summer than in winter, due to increased photochemical oxidation of $\mathrm{SO}_{2}$ to $\mathrm{H}_{2} \mathrm{SO}_{4}$ and subsequent formation of sulfate aerosols in sunnier and warmer conditions (Mihalopoulos et al., 2007). In winter, lower $\mathrm{SO}_{2}$ oxidation rates limits $\mathrm{H}_{2} \mathrm{SO}_{4}$ formation and therefore also the formation of $\left(\mathrm{NH}_{4}\right)_{2} \mathrm{SO}_{4}$.

$\mathrm{Na}^{+}$and $\mathrm{Cl}^{-}$also have highest concentrations during winter, highlighting the importance of marine sources (more stormy weather) in winter for sea salt aerosol. The seasonal trends in $\mathrm{Mg}^{2+}$ are similar to $\mathrm{Na}^{+}$, with maxima during winter and minima in summer (Fig. 8). While sea salt aerosols comprise mainly of $\mathrm{NaCl}$, other chemical ions are also common in seawater, such as $\mathrm{K}^{+}, \mathrm{Mg}^{2+}, \mathrm{Ca}^{2+}$ and $\mathrm{SO}_{4}^{2-}$ (Keene et al., 1986). Some of the sea salt aerosol may therefore be 

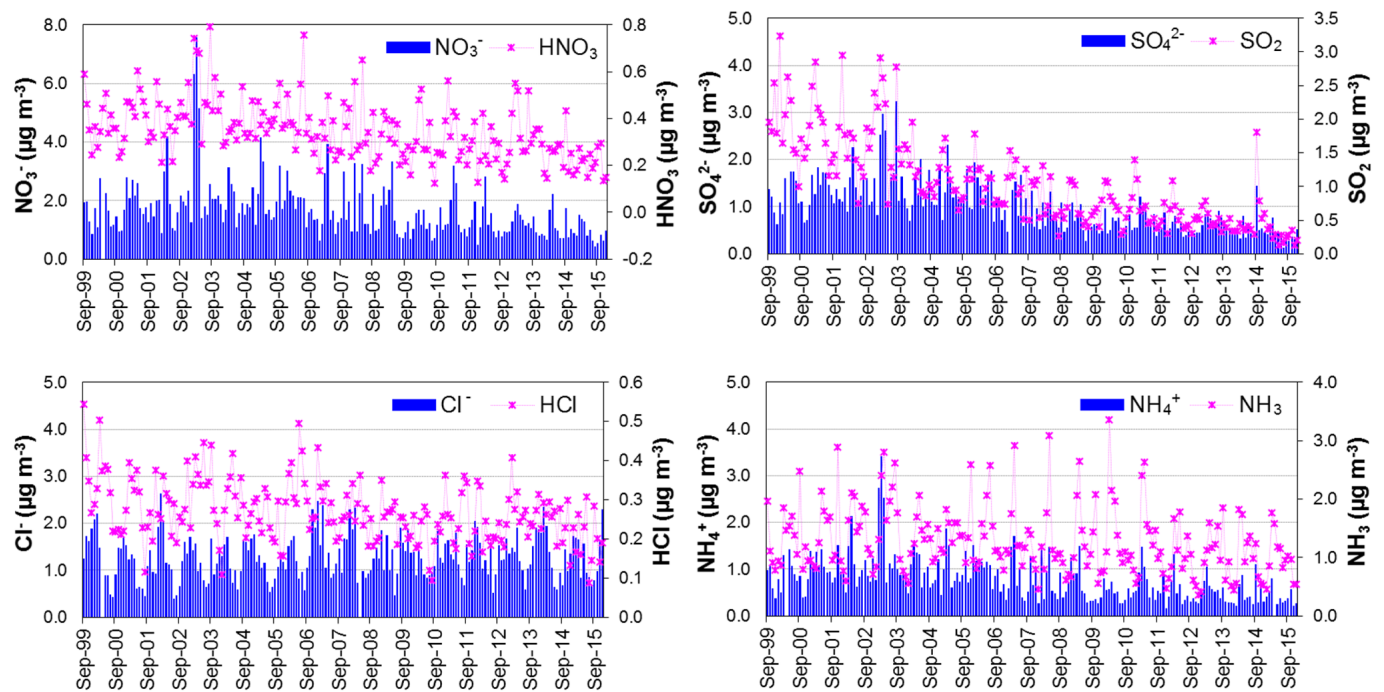

Figure 10. Monthly mean concentrations in gaseous $\mathrm{HNO}_{3}, \mathrm{SO}_{2}, \mathrm{HCl}$ and aerosol $\mathrm{NO}_{3}^{-}, \mathrm{SO}_{4}^{2-}, \mathrm{Cl}^{-}$from the UK Acid Gases and Aerosol Monitoring Network (AGANet). Monthly mean concentrations of $\mathrm{NH}_{3}$ and $\mathrm{NH}_{4}^{+}$that were measured at the same time in the UK National Ammonia Monitoring Network (NAMN, Tang et al., 2018) are also shown for comparison. Each data point in the graphs represents the mean of monthly measurements of 12 sites operational in the network over the period September 1999 to December 2015. The same plots for the full 30 site network from 2006 to 2015 are shown in Fig. S6.

in the form of $\mathrm{MgCl}_{2}$. Magnesium is however also a crustal element, and so it is not as good as sodium as a tracer for sea salt. Similarly, calcium is also a rock-derived element and its presence in the atmosphere is thought to come from chemical weathering of carbonate minerals (Schmitt and Stille, 2005). The seasonal cycle of $\mathrm{Ca}^{2+}$ is similar to, but less pronounced than, $\mathrm{Na}^{+}$and $\mathrm{Mg}^{2+}$. Measured concentrations of $\mathrm{Ca}^{2+}$ were mostly at or below the method LOD which makes interpretation uncertain, but the higher concentrations of $\mathrm{Ca}^{2+}$ in the winter months is likely to be both crustal dust and sea salt in origin.

Large inter- and intra-annual variability are also observed in the long-term mean monthly concentrations of gas and aerosol components, as illustrated in Fig. 10. In 2003, elevated concentrations of $\mathrm{HNO}_{3}$ and $\mathrm{NO}_{3}^{-}$(and also $\mathrm{NH}_{4}^{+}$) were observed between February to April that were more pronounced than the normal peak in concentrations that occur in spring. The large spike in concentrations was of a sufficient magnitude to elevate the annual mean concentrations for 2003 of $\mathrm{HNO}_{3}\left(0.54 \mu \mathrm{g} \mathrm{m}^{-3}\right.$ cf. 0.39 and $0.36 \mu \mathrm{g} \mathrm{m}^{-3}$ for 2002 and 2004, respectively), particulate $\mathrm{NO}_{3}^{-}\left(2.98 \mu \mathrm{g} \mathrm{m}^{-3}\right.$ cf. 1.99 and $1.93 \mu \mathrm{g} \mathrm{m}^{-3}$ for 2002 and 2004 , respectively) and $\mathrm{NH}_{4}^{+}\left(1.45 \mu \mathrm{g} \mathrm{m}^{-3}\right.$ cf. 1.06 and $0.97 \mu \mathrm{g} \mathrm{m}^{-3}$ for 2002 and 2004, respectively). In comparison, a much smaller spike in elevated $\mathrm{SO}_{4}^{2-}$ concentrations resulted in a slight increase in annual average $\mathrm{SO}_{4}^{2-}\left(1.79 \mu \mathrm{g} \mathrm{m}^{-3}\right.$ cf. 1.41 and $1.31 \mathrm{\mu g} \mathrm{m}^{-3}$ for 2002 and 2004, respectively) (Fig. 10). Meteorological back trajectory analysis of the period showed air masses coming across the UK from Europe, and the pollution episode was attributed to the formation and transport of $\mathrm{NH}_{4} \mathrm{NO}_{3}$ from Europe, since other gases $\left(\mathrm{SO}_{2}, \mathrm{HCl}\right.$ and $\mathrm{NH}_{3}$ ) and particulate $\mathrm{Cl}^{-}$were not affected (Vieno et al., 2014). At the same time, stable atmospheric conditions due to a persistent high pressure system over the UK led to an accumulation of pollutant concentrations from both local and import sources. A similar pollution episode, of a shorter duration, occurred in spring 2014. At the time, the observed elevated PM was blamed on a Saharan dust plume, but which in fact was then shown to be from long-range transport of $\mathrm{NH}_{4} \mathrm{NO}_{3}$ (Vieno et al., 2016). Although the 2014 episode was not sufficiently large to be captured in the monthly AGANet data, it reaffirms the substantial contribution of long-range transport into the $\mathrm{UK}$ of $\mathrm{NH}_{4} \mathrm{NO}_{3}$, with precursor gas emissions from outside of the UK presenting a major driver (Vieno et al., 2016).

A second, but smaller pollutant episode that was captured by the AGANet occurred in September 2014, with elevated concentrations of $\mathrm{SO}_{2}, \mathrm{HNO}_{3}, \mathrm{SO}_{4}^{2-}, \mathrm{NO}_{3}^{-}$, and $\mathrm{NH}_{4}^{+}$that came from the Icelandic Holuhraun volcanic eruptions (Twigg et al., 2016). The elevated $\mathrm{SO}_{2}$ concentration in September 2014 led to a modest increase in annual concentrations in $\mathrm{SO}_{2}$ for $2014\left(0.58 \mu \mathrm{g} \mathrm{m}^{-3}\right.$, cf. annual mean $=0.54$ and $0.27 \mu \mathrm{g} \mathrm{m}^{-3}$ for 2013 and 2015 , respectively). For the other components $\left(\mathrm{HNO}_{3}\right.$, particulate $\mathrm{SO}_{4}^{2}$, $\mathrm{NO}_{3}^{-}$and $\mathrm{NH}_{4}^{+}$), the spikes in concentrations were smaller than for $\mathrm{SO}_{2}$ and did not noticeably elevate their annual mean concentrations for that year. These pollution events together illustrate very clearly how short pollutant episodes can have a major influence on the measured annual concentrations in the UK, and that changes in meteorological conditions, cou- 

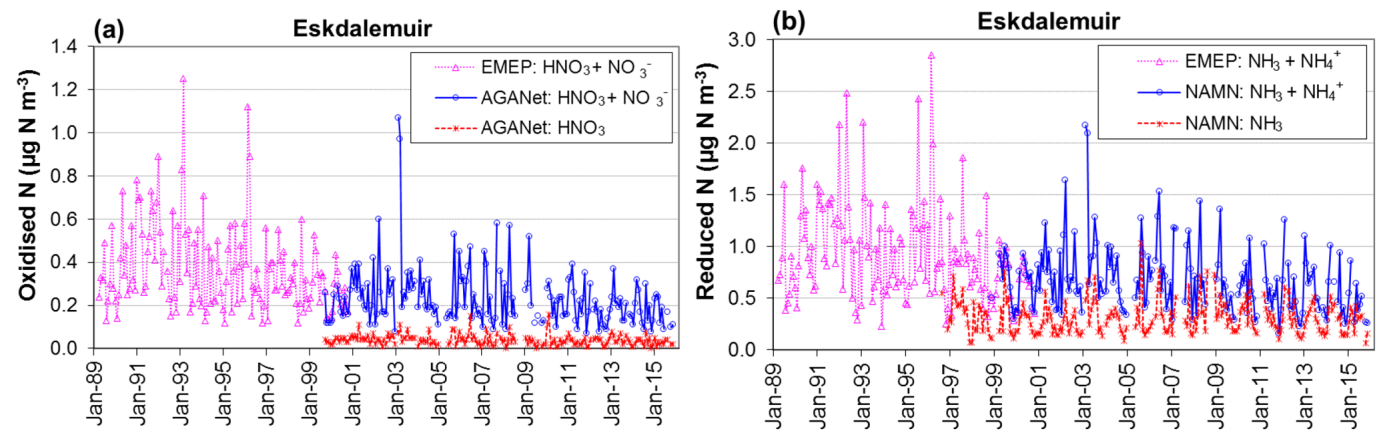

Figure 11. Long-term time series of (a) oxidized nitrogen $\left(\mathrm{HNO}_{3}\right.$ and $\left.\mathrm{NO}_{3}^{-}\right)$and (b) reduced nitrogen $\left(\mathrm{NH}_{3}\right.$ and $\left.\mathrm{NH}_{4}^{+}\right)$concentrations at Eskdalemuir (EMEP station code $=$ GB0002R; UK-AIR ID = UKA00130). EMEP values (EMEP, 2017a) are monthly means of daily measurements for total inorganic nitrogen, TIN (sum of $\mathrm{HNO}_{3}$ and $\mathrm{NO}_{3}^{-}$) and total inorganic nitrogen, TIA (sum of $\mathrm{NH}_{3}$ and $\mathrm{NH}_{4}^{+}$) by the EMEP filter pack method (April 1989-November 2000), matched to the AGANet and NAMN sampling periods (monthly) where the measurements overlap. The AGANet and NAMN data are for gaseous $\mathrm{HNO}_{3}$ and $\mathrm{NH}_{3}$ and for the sum of $\left(\mathrm{HNO}_{3}+\mathrm{NO}_{3}^{-}\right)$and sum of $\left(\mathrm{NH}_{3}+\mathrm{NH}_{4}^{+}\right)$, respectively, by the DELTA method. The AGANet $\mathrm{HNO}_{3}$ values shown here includes the bias correction (Sect. 2.6).

pled with long-range transboundary import can have a large effect on the UK concentration field.

\subsection{Long-term trends at Eskdalemuir}

At the Eskdalemuir rural background site, EMEP filter pack data in TIN (sum of $\mathrm{HNO}_{3}$ and $\mathrm{NO}_{3}^{-}$) and TIA (sum of $\mathrm{NH}_{3}$ and $\mathrm{NH}_{4}^{+}$) are available since 1989 (Sect. 3.1.2). In Fig. 11, the EMEP filter pack TIN and TIA time series (April 1989 to December 2000) is extended with AGANet $\left(\mathrm{HNO}_{3}\right.$ and $\left.\mathrm{NO}_{3}^{-}\right)$and NAMN $\left(\mathrm{NH}_{3}\right.$ and $\left.\mathrm{NH}_{4}^{+}\right)$DELTA data (September 1999 to December 2015), with an overlapping period of 14 months. The combined time series shows that the annual concentrations of TIN has halved in 26 years between 1990 to 2015 , from 0.36 to $0.16 \mu \mathrm{g} \mathrm{N} \mathrm{m}{ }^{-3}$, compared with a 3-fold reduction in $\mathrm{NO}_{x}$ emissions (from 928 to $302 \mathrm{kt} \mathrm{NO}_{2}-\mathrm{N}$ ) (NAEI, 2018) over the same period. For TIA, the $52 \%$ decrease between 1990 to 2015 (from 0.93 to $0.45 \mu \mathrm{g} \mathrm{N} \mathrm{m}^{-3}$ ) is larger than the corresponding $13 \%$ reduction in $\mathrm{NH}_{3}$ emissions (from 265 to $231 \mathrm{kt} \mathrm{NH}_{3}-\mathrm{N}$ ) (NAEI, 2018). Speciated $\mathrm{NH}_{3}$ and $\mathrm{NH}_{4}^{+}$data from NAMN over the period 2000-2015 shows that the decrease in TIA is mainly driven by $\mathrm{NH}_{4}^{+}$, which decreased by $59 \%$ between 2000 (annual mean $=0.62 \mu \mathrm{g} \mathrm{NH}_{4}^{+} \mathrm{m}^{-3}$ ) and 2015 (annual mean $\left.=0.25 \mu \mathrm{g} \mathrm{NH}_{4}^{+} \mathrm{m}^{-3}\right)$, compared with no change in $\mathrm{NH}_{3}$ (annual mean $0.32 \mu \mathrm{g} \mathrm{NH} \mathrm{m}^{-3}$ in 2000 , unchanged in 2015). This is consistent with findings by Tang et al. (2018) that contrary to the reported decrease in $\mathrm{UK} \mathrm{NH}_{3}$ emissions, $\mathrm{NH}_{3}$ concentrations at background sites (defined by $5 \mathrm{~km}$ grid average $\mathrm{NH}_{3}$ emissions $<1 \mathrm{~kg} \mathrm{Nha}^{-1} \mathrm{yr}^{-1}$ ) are showing an indicative increasing trend, while at the same time, a large downward trend in particulate $\mathrm{NH}_{4}^{+}$is observed. Together, the AGAnet and NAMN are thus providing an important long-term dataset that distinguishes between the gas and aerosol phase, allowing gas-aerosol phase interactions to be explored.
An extended time series illustrating the continued decline in $\mathrm{SO}_{2}$ and $\mathrm{SO}_{4}^{2-}$ has also been constructed by combining historic $\mathrm{SO}_{2}$ and $\mathrm{SO}_{4}^{2-}$ measurement data at the Eskdalemuir site going back to December 1977 (see Sect. 3.1.3) with AGANet $\mathrm{SO}_{2}$ and $\mathrm{SO}_{4}^{2-}$ data (September 1999 to December 2015) (Fig. 12). A substantial decline in $\mathrm{SO}_{2}$ is observed, falling by $98 \%$ from $4.5 \mu \mathrm{g} \mathrm{S} \mathrm{m}^{-3}$ in 1978 to $0.07 \mu \mathrm{g} \mathrm{S} \mathrm{m}{ }^{-3}$ in 2015 , in good agreement with similarly large reduction in UK SO 2 emissions over the same period of $95 \%$ (from 2570 to $126 \mathrm{kt} \mathrm{SO}_{2}-\mathrm{S}$ ) (NAEI, 2018). The decrease in $\mathrm{SO}_{4}^{2-}$ is of a smaller magnitude, declining by $88 \%$ from an annual mean concentration of $0.89 \mu \mathrm{g} \mathrm{S} \mathrm{m}^{-3}$ in 1978 to $0.11 \mu \mathrm{g} \mathrm{S} \mathrm{m}^{-3}$ in 2015, highlighting the non-linearity in relationship between the atmospheric gas and aerosol phase of sulfur at this background site.

\subsection{Assessment of trends in relation to UK emissions}

The long-term time series in annually averaged concentrations of the gas and aerosol components are compared in Fig. 13a and b, respectively. Since there was a change in the number of sites during the operation of the AGANet, annually averaged data from the original 12 sites for the period 2000-2015 (1999 data excluded since AGANet started in September 1999) and from the full network (30 sites) for the period 2006-2015 are plotted alongside each other for comparison. From 2006-2015, the decreasing trends for all gas and aerosol components from the expanded 30 sites are seen to be similar to those from the original 12 sites. The annual mean concentrations in gas and aerosol components derived from the expanded 30 sites (2006-2015) or from the original 12 sites over the same period are also in general comparable (Table 3). The exceptions are $\mathrm{Na}^{+}$and $\mathrm{Cl}^{-}$that have higher mean concentrations from the 30 sites than the original 12 sites (Table 3), due to the addition of two coastal sites (Shetland and Rum), with larger contribution from sea 


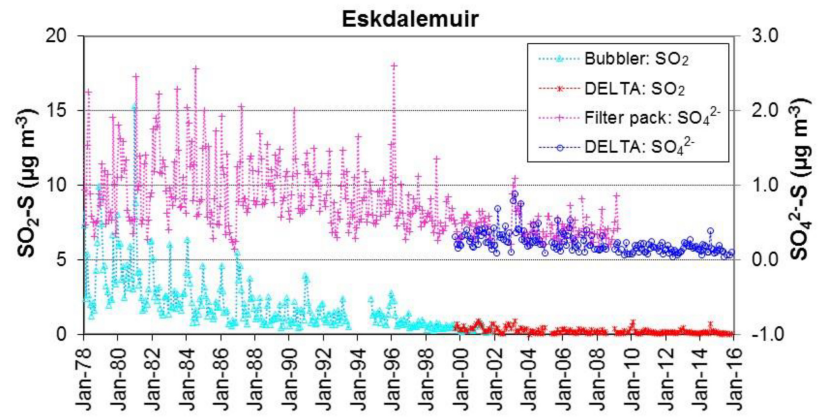

Figure 12. Long-term time series of $\mathrm{SO}_{2}$ (December 1977July 1993) and $\mathrm{SO}_{4}^{2-}$ (December 1977-December 2001) concentrations measured in the UK Acid Deposition Monitoring Network (ADMN) (Hayman et al., 2007) and the AGANet DELTA measurements (October 1999-December 2015) at the Eskdalemuir monitoring station (EMEP station code = GB0002R; UKAIR ID = UKA00130). ADMN values (EMEP, 2017b) are monthly means of daily measurements for $\mathrm{SO}_{2}$ and $\mathrm{SO}_{4}^{2-}$ by a daily bubbler and filter pack method, respectively, matched to the AGANet sampling periods (monthly) where the measurements overlap.

salt. Larger $\mathrm{HNO}_{3}$ concentrations are due to two urban sites, London and Edinburgh (higher $\mathrm{NO}_{x}$ emissions from vehicular traffic). The addition of three sites in high $\mathrm{NH}_{3}$ emission (agricultural) areas (Rosemaund in England, Narberth in Wales and Hillsborough in Northern Ireland) also elevated measured annual mean $\mathrm{NH}_{3}$ concentrations. The comparisons here thus illustrate very clearly the need to consider the effect of site changes in a national network and the importance of maintaining consistency and site continuity for assessing long-term trends.

In the gas phase, $\mathrm{SO}_{2}$ decreased 7 -fold from an annual mean concentration of $1.9 \mu \mathrm{g} \mathrm{SO}_{2} \mathrm{~m}^{-3}$ in 2000 to $0.25 \mu \mathrm{g} \mathrm{SO}_{2} \mathrm{~m}^{-3}$ in $2015 \quad(n=12)$, compared with more modest reductions in $\mathrm{HNO}_{3}$ (from 0.35 to $0.21 \mu \mathrm{g} \mathrm{HNO}_{3} \mathrm{~m}^{-3}$ ), $\mathrm{NH}_{3}$ (from 1.4 to $1.0 \mu \mathrm{g} \mathrm{NH} \mathrm{NH}^{-3}$ ) and $\mathrm{HCl}$ (from 0.31 to $0.20 \mu \mathrm{g} \mathrm{HCl} \mathrm{m}^{-3}$ ) over the same period (Fig. 13a). Particulate $\mathrm{SO}_{4}^{2-}, \mathrm{NO}_{3}^{-}$, and $\mathrm{NH}_{4}^{+}$also decreased in concentrations with time, but unlike their gas phase precursors, the trends of these aerosol components track each other closely, differing only in the magnitude of concentrations (Fig. 13b), illustrating very clearly the close coupling between these components. On the other hand, the absence of a trend in the particulate $\mathrm{Cl}^{-}$is likely to reflect the sea salt origin of $\mathrm{Cl}^{-}$which is not expected to vary over time.

Important changes in the chemical climate is captured by the parallel monitoring of acid gases and aerosols in AGANet and of $\mathrm{NH}_{3}, \mathrm{NH}_{4}^{+}$in NAMN. It is clear from the long-term data that there is substantial intra- (Fig. 10) and inter-annual variability in the annual mean concentrations of both the gas and aerosol phases (Fig. 13), in particular the spike in concentrations in 2003 (see Sect. 3.6) that buckles the trend. An
Table 3. Comparison of mean concentrations from the original 12 Acid Gases and Aerosol Network (AGANet) sites vs. the expanded 30 AGANet sites for the different gas and aerosol components. $\mathrm{NH}_{3}$ and $\mathrm{NH}_{4}^{+}$measured at the same time in the UK National Ammonia Monitoring Network (NAMN, Tang et al., 2018) are also included for comparison. Each data point are the mean \pm SD of annual mean concentrations over the period 2006 to 2015.

\begin{tabular}{lrr}
\hline $\begin{array}{l}\text { Mean concentration } \\
(2006-2015),\end{array}$ & $\begin{array}{r}12 \text { sites } \\
(\text { mean } \pm \mathrm{SD})\end{array}$ & $\begin{array}{r}30 \text { sites } \\
(\text { mean } \pm \mathrm{SD})\end{array}$ \\
$\mu \mathrm{g} \mathrm{m}^{-3}$ & & \\
\hline $\mathrm{HNO}_{3}$ & $0.31 \pm 0.06$ & $0.34 \pm 0.06$ \\
$\mathrm{SO}_{2}$ & $0.66 \pm 0.24$ & $0.70 \pm 0.25$ \\
$\mathrm{HCl}$ & $0.25 \pm 0.04$ & $0.28 \pm 0.04$ \\
$\mathrm{NO}_{3}^{-}$ & $1.40 \pm 0.31$ & $1.41 \pm 0.26$ \\
$\mathrm{SO}_{4}^{2-}$ & $0.73 \pm 0.25$ & $0.74 \pm 0.23$ \\
$\mathrm{Cl}^{-}$ & $1.33 \pm 0.09$ & $1.54 \pm 0.09$ \\
$\mathrm{Na}^{+}$ & $0.75 \pm 0.07$ & $0.84 \pm 0.08$ \\
$\mathrm{Ca}^{2+}$ & $0.04 \pm 0.03$ & $0.04 \pm 0.02$ \\
$\mathrm{Mg}^{2+}$ & $0.06 \pm 0.01$ & $0.07 \pm 0.01$ \\
$\mathrm{NH}_{3}$ & $1.18 \pm 0.16$ & $1.40 \pm 0.16$ \\
$\mathrm{NH}_{4}^{+}$ & $0.62 \pm 0.18$ & $0.61 \pm 0.16$ \\
\hline
\end{tabular}

interpretation of the direct relationship between emissions and concentrations in the atmosphere is therefore not straight forward, as the concentrations are also influenced by other factors such as variations in meteorological conditions and long-range transboundary import into the UK.

In Fig. 14, the relative trends in $\mathrm{UK} \mathrm{NO}_{x}, \mathrm{SO}_{2}, \mathrm{HCl}$ and $\mathrm{NH}_{3}$ emissions (NAEI, 2018) are compared with the annually averaged gas and particulate concentrations measured in the AGANet and NAMN for (i) original 12 sites for the 16 year period from 2000 to 2015, (ii) original 12 sites for the 15 year period from 2001 to 2015 (because annual mean concentrations in 2000 for all components were smaller than in 2001-2006), and (iii) expanded 30 sites and also original 12 sites for the 10 year period from 2006 to 2015. All data were normalized to 0 for the start years in each of the comparison.

The long-term trends in $\mathrm{HNO}_{3}, \mathrm{SO}_{2}, \mathrm{HCl}$ and particulate $\mathrm{NO}_{3}^{-}, \mathrm{SO}_{4}^{2-}, \mathrm{Cl}^{-}$, based on $\mathrm{MK}$ statistical trend analysis (Sect. 2.7) of annual mean measurement data are compared in Fig. 15 and summarized in Table 4 for the two time series: (i) the original 12 AGANet sites for the 16 year period from 2000 to 2015, and (ii) the expanded 30 AGANet sites for the 10 year period from 2006 to 2015 . This approach avoids introducing bias as a result of changes in the sites and ensures site continuity for the long-term trend assessment. $\mathrm{NH}_{3}$ and $\mathrm{NH}_{4}^{+}$concentrations from the NAMN that were measured at the same time at the AGANet sites were included for comparison and to aid interpretation of the acid gas and aerosol data.

To quantify changes in measured concentrations over time, annual trends (e.g. $\mu \mathrm{g} \mathrm{HNO}_{3} \mathrm{~m}^{-3} \mathrm{yr}^{-1}$ ) are estimated from 
(a)

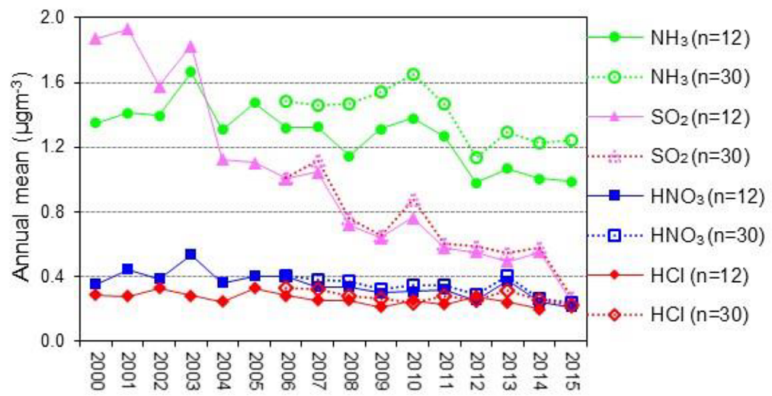

(b)

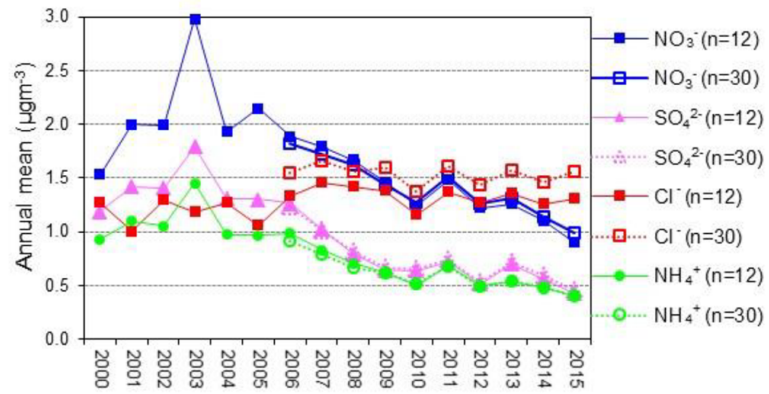

Figure 13. Long-term trends in (a) acid gases and (b) aerosol concentrations ( $\mu$ g molecule $\mathrm{m}^{-3}$ ) from the UK Acid Gases and Aerosol Network (AGANet). Each data point represents the annually averaged measurements from either the original 12 AGANet sites for the 16year period from 2000 to 2015 or the expanded 30 AGANet sites for the 10-year period from 2006 to $2015 . \mathrm{NH}_{3}$ and particulate $\mathrm{NH}_{4}^{+}$ measured at the same time in the UK National Ammonia Monitoring Network (NAMN, Tang et al., 2018) are also included for comparison.

Table 4. Summary of Mann-Kendall (MK) time series trend analysis on annually averaged gas and aerosol concentrations from the UK Acid Gases and Aerosol Monitoring Network (AGANet) for (i) 12 sites that were operational over the period 2000 to 2015 and (ii) 30 sites that were operational over the period 2006 to $2015 . \mathrm{NH}_{3}$ and $\mathrm{NH}_{4}^{+}$concentrations data measured at the same time from the UK National Ammonia Monitoring Network (NAMN, Tang et al., 2018) are also included for comparison. The $95 \%$ confidence interval (CI) for the median trend and relative median change (\%) are also estimated.

\begin{tabular}{|c|c|c|c|c|}
\hline \multirow{2}{*}{$\begin{array}{l}\text { Annual mean data } \\
\left(\mu \mathrm{g} \mathrm{m}^{-3}\right)\end{array}$} & \multicolumn{2}{|c|}{ Mann-Kendall (MK): 12 sites (2000-2015) } & \multicolumn{2}{|c|}{ Mann-Kendall (MK): 30 sites (2006-2015) } \\
\hline & $\begin{array}{l}\text { a Median annual trend } \\
\&[95 \% \mathrm{CI}]\left(\mu \mathrm{g} \mathrm{yr}^{-1}\right)\end{array}$ & $\begin{array}{l}{ }^{\mathrm{b}} \text { Relative median } \\
\text { change \& }[95 \% \mathrm{CI}] \\
(\%)\end{array}$ & $\begin{array}{l}\text { a Median annual trend } \\
\&[95 \% \mathrm{CI}]\left(\mu \mathrm{g} \mathrm{yr}^{-1}\right)\end{array}$ & $\begin{array}{l}{ }^{\mathrm{b}} \text { Relative median } \\
\text { change \& }[95 \% \mathrm{CI}] \\
(\%)\end{array}$ \\
\hline $\mathrm{HNO}_{3}$ & $\begin{array}{l}-0.0135^{* *} \\
{[-0.0067,-0.0180]}\end{array}$ & $-45^{* *}[-26,-55]$ & $\begin{array}{l}-0.0167^{*} \\
{[-0.0075,-0.0200]}\end{array}$ & $-36^{*}[-18,-41]$ \\
\hline $\mathrm{SO}_{2}$ & $\begin{array}{l}-0.1010^{* * *} \\
{[-0.0729,-0.1255]}\end{array}$ & $-81^{* * *}[-72,-91]$ & $\begin{array}{l}-0.0717^{* *} \\
{[-0.0300,-0.0108]}\end{array}$ & $-60^{* *}[-33,-73]$ \\
\hline $\mathrm{HCl}$ & $\begin{array}{l}-0.0057^{* *} \\
{[-0.0020,-0.0100]}\end{array}$ & $-28^{* *}[-11,-42]$ & $\begin{array}{l}-0.0088^{*} \\
{[0.0000,-0.0200]}\end{array}$ & $-24^{*}[0.0,-47]$ \\
\hline $\mathrm{NH}_{3}$ & $\begin{array}{l}-0.0300^{* *} \\
{[-0.0125,-0.0433]}\end{array}$ & $-30^{* * *}[-13,-39]$ & $\begin{array}{l}-0.0312^{\mathrm{ns}} \\
{[0.0033,-0.0625]}\end{array}$ & $-18^{\mathrm{ns}}[+2.0,-31]$ \\
\hline $\mathrm{NO}_{3}^{-}$ & $\begin{array}{l}-0.0810^{* * *} \\
{[-0.0520,-0.1125]}\end{array}$ & $-52^{* * *}[-37,-63]$ & $\begin{array}{l}-0.0900^{* *} \\
{[-0.0580,-0.1300]}\end{array}$ & $-43^{* *}[-30,-56]$ \\
\hline $\mathrm{SO}_{4}^{2-}$ & $\begin{array}{l}-0.0750^{* * *} \\
{[-0.0450,-0 .-0988]}\end{array}$ & $-69^{* * *}[-52,-82]$ & $\begin{array}{l}-0.0675^{* *} \\
{[-0.0233,-0.1167]}\end{array}$ & $-54^{* *}[-25,-78]$ \\
\hline nss_SO ${ }_{4}^{2-}$ & $\begin{array}{l}-0.0733^{* * *} \\
{[-0.0500,-0 .-1012]}\end{array}$ & $-78^{* * *}[-64,-92]$ & $\begin{array}{l}-0.0575^{* *} \\
{[-0.0167,-0.1033]}\end{array}$ & $-62^{* *}[-25,-86]$ \\
\hline $\mathrm{Cl}^{-}$ & $\begin{array}{l}0.0079^{\mathrm{ns}} \\
{[-0088,0.0236]}\end{array}$ & $9.6^{\mathrm{ns}}[-9.5,33]$ & $\begin{array}{l}-0.0075^{\mathrm{ns}} \\
{[+0.0167,-0.0300]}\end{array}$ & $-4.2^{\mathrm{ns}}[+10,-16]$ \\
\hline $\mathrm{NH}_{4}^{+}$ & $\begin{array}{l}-0.0500^{* * *} \\
{[-0.0375,-0.0675]}\end{array}$ & $-62^{* * *}[-51,-74]$ & $\begin{array}{l}-0.0480^{* *} \\
{[0.0267,-0.0700]}\end{array}$ & $-49^{* *}[-33,-64]$ \\
\hline
\end{tabular}

Significance level: ${ }^{*} p<0.05,{ }^{* *} p<0.01,{ }^{* * *} p<0.001,{ }^{\text {ns }}$ non-significant $(p>0.05)$.

a Median annual trend $=$ fitted Sen's slope of Mann-Kendall linear trend $\left(\right.$ unit $\left.=\mu \mathrm{g} \mathrm{yr}{ }^{-1}\right) .{ }^{\mathrm{b}}$ Relative median change estimated from the annual concentration at the start $\left(y_{0}\right)$ and at the end $\left(y_{i}\right)$ of time series computed from the Sen's slope and intercept $\left(=100 \times\left[\left(y_{i}-y_{0}\right) / y_{0}\right]\right)$.

the regression results of the MK tests. This is considered as providing a more reliable estimate of trend than comparing measured annual concentrations at the beginning and end of the time series, which is subject to bias due to substantial variability in annual concentrations between years (Tang et al., 2018). Changes in measured concentrations over time (MK percentage median change) in the time series are estimated from the MK Sen's slope and intercept (Eq. 6). MK annual trends and percentage median change are summarized in Fig. 15 and Table 4. 
(a)
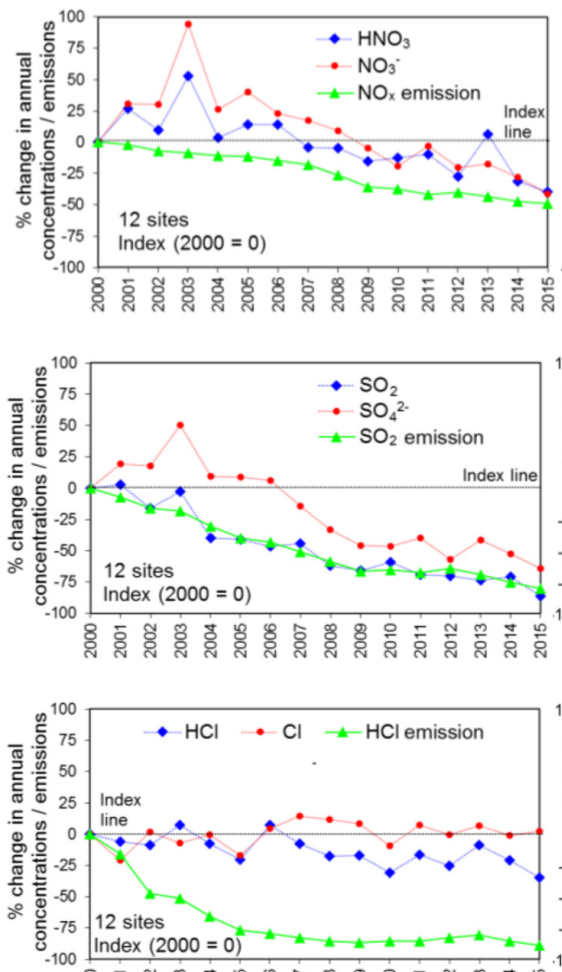

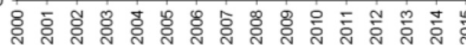

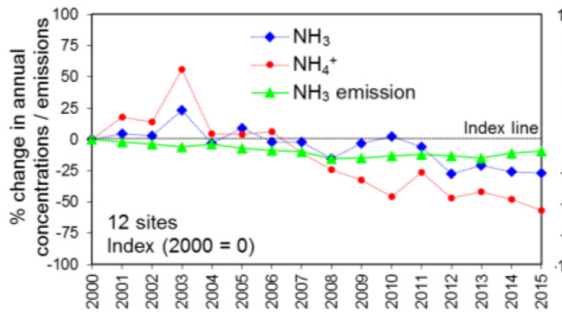

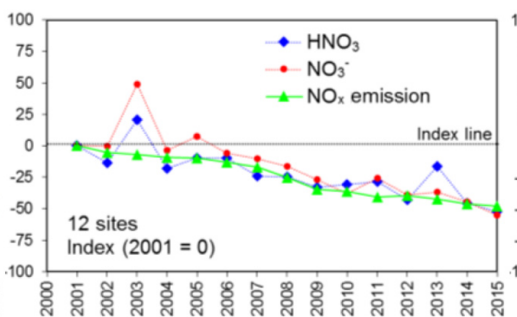

(b)
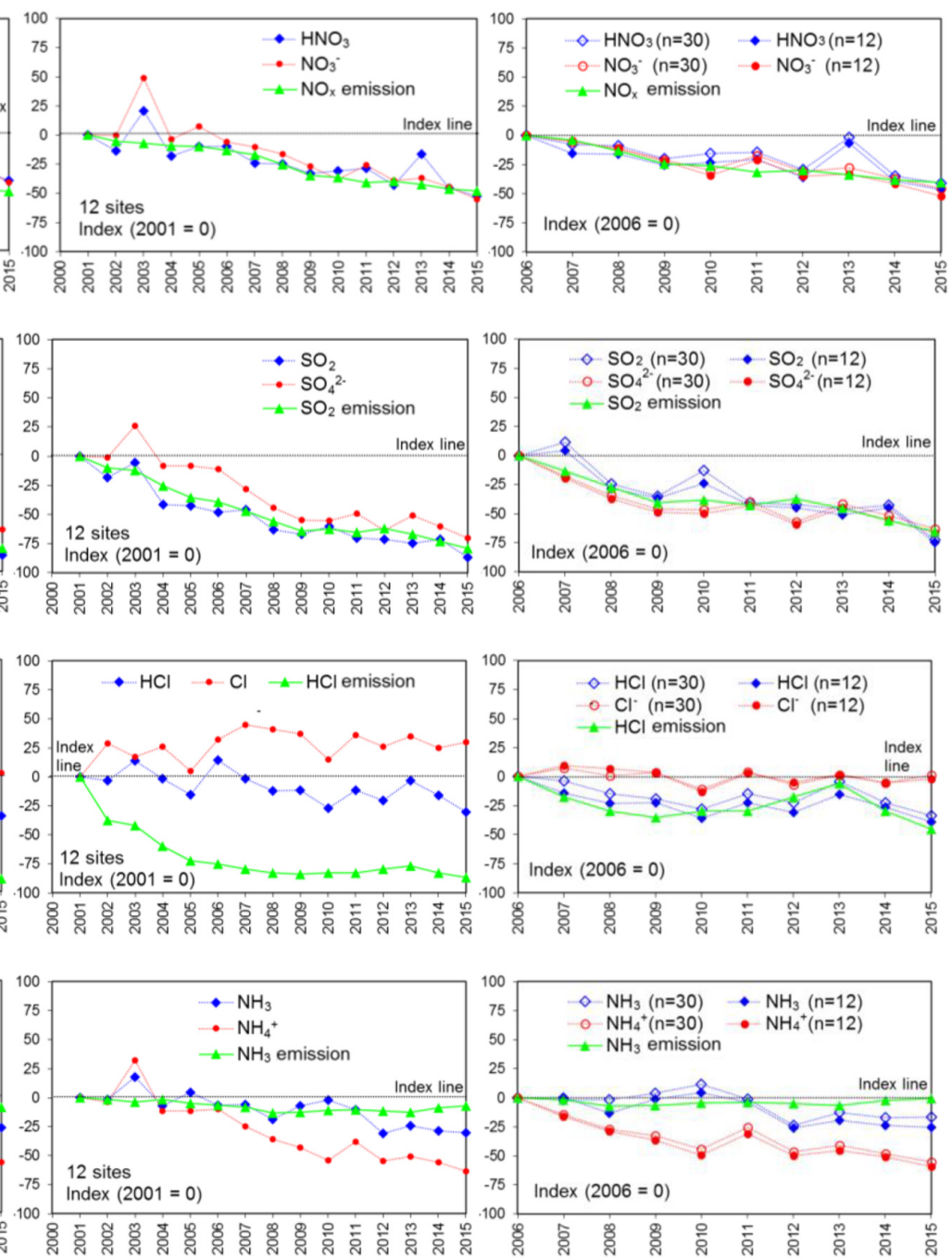

Figure 14. Relative trends in UK emissions (NAEI, 2018) and in annually averaged gas and particulate concentrations from the UK AGANet and UK National Ammonia Monitoring Network (NAMN, Tang et al., 2018) for (a) the original 12 sites for the 16 year period from 2000 to 2015, and (b) expanded 30 sites compared with the original 12 sites for the 10 year period from 2006 to 2015.

$\%$ median change $=100 \cdot \frac{\left[y_{i}-y_{0}\right)}{y_{0}}$,

where $\left(y_{0}\right)$ and $\left(y_{i}\right)$ are estimated annual mean concentrations at the start and end of the selected time period, estimated from the slope and intercept of the LR or MK tests.

Statistical trend analysis of monthly mean measurement data in the gas and aerosol components are also shown for comparison in Fig. S3 (mean monthly data of 12 sites for period 2000-2015) and Fig. S4 (mean monthly data of 12 sites for period 2006-2015). MK annual trends and percentage median change, based on the monthly data (Tables S7, S8) were similar to the annual test results (Table 4). While not discussed further here, since assessment of long-term trends in this paper focuses on trends in annual mean concentrations for comparison with trends in estimated annual emissions, the monthly plots serves to illustrate the large intra-annual variability of concentrations in gases and aerosols.

\subsubsection{Trends in $\mathrm{HNO}_{3}$ and $\mathrm{NO}_{3}^{-}$vs. $\mathrm{NO}_{x}$ emissions}

The overall downward trends in $\mathrm{HNO}_{3}$ and $\mathrm{NO}_{3}^{-}$are seen to be broadly consistent with the $-49 \%$ fall in estimated $\mathrm{NO}_{x}$ emissions (NAEI, 2018) over the 16 year period between 2000 and 2015 (Fig. 14). Reductions in combustion (power stations and industrial) and vehicular sources (fitting of catalytic converters), coupled to tighter regulations are major contributory factors to the decrease in $\mathrm{UK} \mathrm{NO}_{x}$ emissions. The rate of reduction however stagnated in the period 2009 

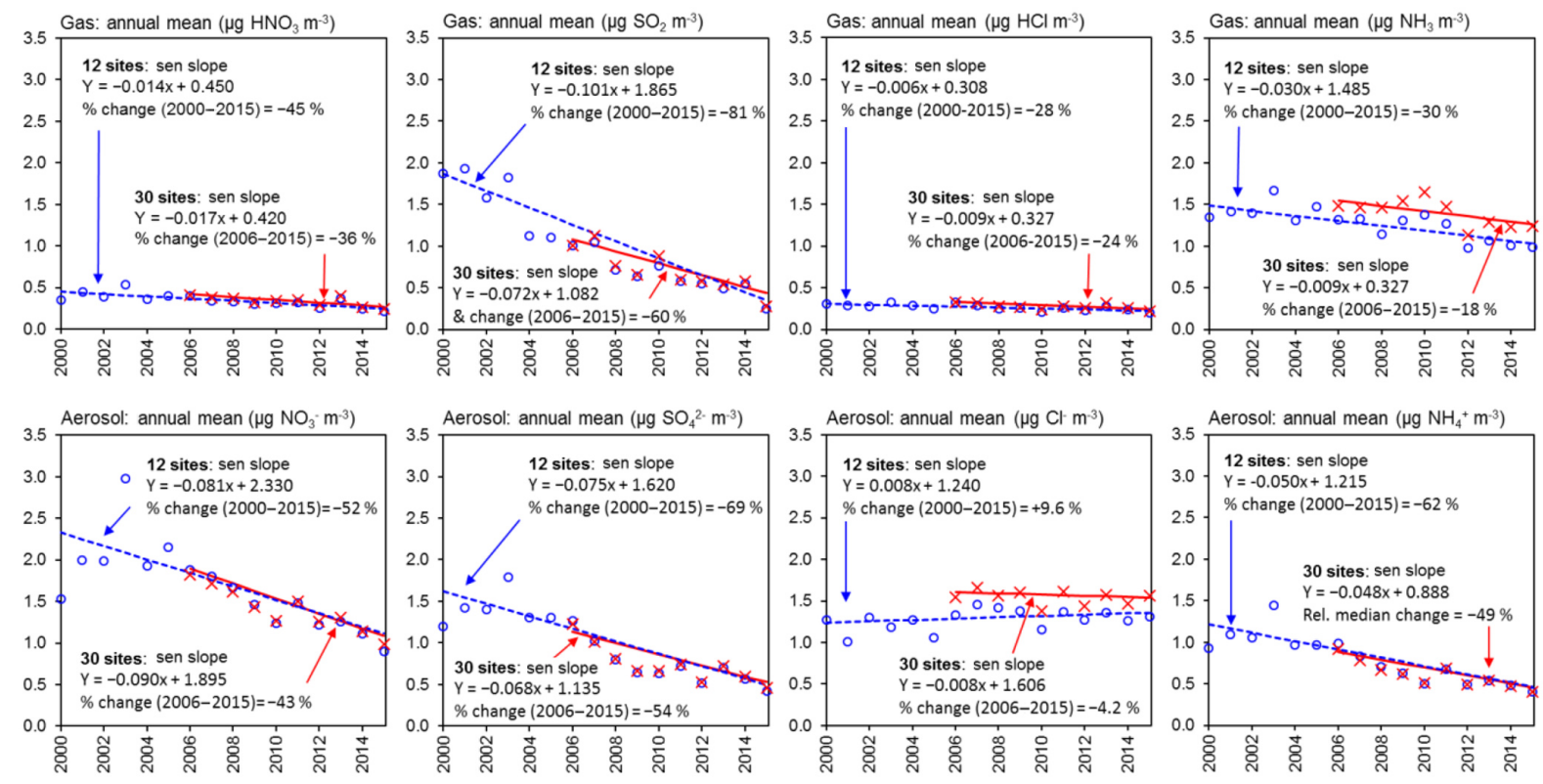

Figure 15. Time series trend analysis by non-parametric Mann-Kendall Sen slope on annually averaged gas and aerosol concentration data from the UK Acid Gases and Aerosol Monitoring Network (AGANet) of (i) 12 sites with complete time series over the period 2000-2015 and (ii) expanded 30 sites with complete times series over the period 2006-2015. $\mathrm{NH}_{3}$ and $\mathrm{NH}_{4}^{+}$concentrations data measured at the same time in the UK National Ammonia Monitoring Network (NAMN, Tang et al., 2018) are also included for comparison.

and 2012 (improvement in emissions abatement offset by proportionate increase from diesel combustion and increase in vehicle numbers), followed by a $16 \%$ decrease between 2012 and 2015 due to the closure of a number of coal-fired power stations.

It is notable that the first 6 years (2000-2006) of $\mathrm{HNO}_{3}$ and $\mathrm{NO}_{3}^{-}$annual data show substantial variability between years and in particular is dominated by the large 2003 peak in concentrations (see Sect. 3.6). This highlights the sensitivity of the trend assessment to the selection of a reference start for the time series, since the annual mean concentrations of both $\mathrm{HNO}_{3}$ and $\mathrm{NO}_{3}^{-}$in 2000 are in fact smaller than concentrations in the following 6 years. Re-analysis of the same annual data normalized against 2001 instead of 2000 takes the relative trend lines for $\mathrm{HNO}_{3}$ and $\mathrm{NO}_{3}^{-}$much closer to the relative trend line in $\mathrm{NO}_{x}$ emissions. In the later period between 2006 and 2015, the relative trend lines in $\mathrm{HNO}_{3}$ and $\mathrm{NO}_{3}^{-}$derived from the mean of either 12 or 30 sites were not significantly different, and the relative trend lines in emission and concentrations followed each other closely (Fig. 14).

Results of MK tests showed that the reductions in annual $\mathrm{HNO}_{3}$ concentrations are statistically significant for both time series (Fig. 15; Table 4). The MK percentage median change in annual mean $\mathrm{HNO}_{3}$ was $-45 \%$ (2000$2015, n=12)$ and $-36 \%(2006-2015, n=30)$, consistent with the $-49 \%$ and $-40 \%$ fall in estimated $\mathrm{NO}_{x}$ emissions over the corresponding periods (Table 5). The decrease in $\mathrm{HNO}_{3}$ is accompanied by a larger decrease in particulate $\mathrm{NO}_{3}^{-}(2000-2015: \mathrm{MK}=-52 \%(n=12), 2006-2015$ :
MK $=-43 \%(n=30))$ (Table 4$)$ and an indicative small increasing trend is observed in the ratio of $\mathrm{HNO}_{3}$ to $\mathrm{NO}_{3}^{-}$ with time (Fig. 16), hinting at an increased partitioning to the gas phase. Since $\mathrm{HNO}_{3}$ is one of the major oxidation products of $\mathrm{NO}_{x}$, through reaction with $\mathrm{OH}$ or heterogeneous conversion of $\mathrm{N}_{2} \mathrm{O}_{5}$, it provides an important measure of the fraction of $\mathrm{NO}_{x}$ emissions that is oxidized and signals any long-term changes in the atmospheric processing timescales of $\mathrm{NO}_{x}$ over the country. $\mathrm{NO}_{2}$ is measured at 24 rural sites across the UK in the UKEAP $\mathrm{NO}_{2}$-net, with 11 sites collocated with the AGANet (Conolly et al., 2016). The long-term time series in the data also showed a matching decreasing trend in network averaged $\mathrm{NO}_{2}$ concentrations with $\mathrm{NO}_{x}$ emissions between 2000 and 2015, with annual mean $\mathrm{NO}_{2}$ concentrations across the network falling 2-fold to $4 \mu \mathrm{g} \mathrm{NO}_{2} \mathrm{~m}^{-3}$ in 2015 (Conolly et al., 2016). Despite the uncertainty in corrected $\mathrm{HNO}_{3}$ data (Sect. 3.3), the encouraging agreement between trends in $\mathrm{HNO}_{3}$ and $\mathrm{NO}_{2}$ concentrations and $\mathrm{NO}_{x}$ emissions lends support to a linear response in $\mathrm{HNO}_{3}$ concentrations to reductions in $\mathrm{NO}_{x}$ emissions.

\subsubsection{Trends in $\mathrm{SO}_{2}$ and $\mathrm{SO}_{4}^{2-}$ vs. $\mathrm{SO}_{2}$ emissions}

Unlike $\mathrm{NO}_{x}$, there has been a more significant decline in $\mathrm{SO}_{2}$, both in emissions and measured concentrations during this period (Fig. 14). Between 2000 and 2009, $\mathrm{SO}_{2}$ emissions fell substantially by $66 \%$ from 1286 to $432 \mathrm{kt} \mathrm{SO}_{2}$. The reduction reflects mitigation measures introduced since the 1980s (fitting of flue gas desulfurization to coal fired power 
Table 5. Comparison of percentage change in estimated $\mathrm{UK} \mathrm{NO}_{x}, \mathrm{SO}_{2}$, and $\mathrm{NH}_{3}$ emissions reported by the National Atmospheric Emission Inventory (NAEI, 2018) with \% change between 2000 and 2015 (12 sites with complete time series) and between 2006 and 2015 (30 sites with complete time series) in annually averaged $\mathrm{HNO}_{3} / \mathrm{NO}_{3}^{-}$and $\mathrm{SO}_{2} / \mathrm{SO}_{4}^{2-}$ concentrations from the UK Acid Gas and Aerosol Monitoring Network (AGANet), and annually averaged $\mathrm{NH}_{3} / \mathrm{NH}_{4}^{+}$concentrations from the UK National Ammonia Monitoring Network (NAMN, Tang et al., 2018).

\begin{tabular}{|c|c|c|c|c|}
\hline \multirow[t]{2}{*}{ Components } & \multicolumn{2}{|c|}{ 2000-2015 (12 sites) } & \multicolumn{2}{|c|}{ 2006-2015 (30 sites) } \\
\hline & $\begin{array}{l}\text { UK emissions }{ }^{\mathrm{b}} \\
\% \text { change }\end{array}$ & $\begin{array}{l}\text { MK Sen Slope } \\
\% \text { relative median } \\
\text { change }^{\mathrm{a}}\end{array}$ & $\begin{array}{l}\text { UK emissions }{ }^{\mathrm{b}} \\
\% \text { change }\end{array}$ & $\begin{array}{l}\text { MK Sen slope } \\
\% \text { relative median } \\
\text { change }^{\mathrm{a}}\end{array}$ \\
\hline Gas $\mathrm{HNO}_{3}$ & $-49\left(\mathrm{NO}_{x}\right)$ & $-45^{* *}$ & $-40\left(\mathrm{NO}_{x}\right)$ & $-36^{*}$ \\
\hline Particulate $\mathrm{NO}_{3}^{-}$ & & $-52^{* * *}$ & & $-43^{* *}$ \\
\hline Gas $\mathrm{SO}_{2}$ & $-80\left(\mathrm{SO}_{2}\right)$ & $-81^{* * *}$ & $-65\left(\mathrm{SO}_{2}\right)$ & $-60^{* * *}$ \\
\hline Particulate $\mathrm{SO}_{4}^{2-}$ & & $-69^{* * *}$ & & $-54^{* *}$ \\
\hline nss_SO $\mathrm{SO}_{4}^{2-}$ & & $-78^{* * *}$ & & $-62^{* *}$ \\
\hline $\mathrm{Gas} \mathrm{HCl}$ & $-87(\mathrm{HCl})$ & $-28^{\mathrm{ns}}$ & $-45(\mathrm{HCl})$ & $-24^{\mathrm{ns}}$ \\
\hline Particulate $\mathrm{Cl}^{-}$ & & $+10^{\mathrm{ns}}$ & & $-4^{\mathrm{ns}}$ \\
\hline Gas $\mathrm{NH}_{3}$ & $-9\left(\mathrm{NH}_{3}\right)$ & $-30^{* * *}$ & $-0.7\left(\mathrm{NH}_{3}\right)$ & $-18^{\mathrm{ns}}$ \\
\hline Particulate $\mathrm{NH}_{4}^{+}$ & & $-62^{* * *}$ & & $-49^{* *}$ \\
\hline
\end{tabular}

Significance level: ${ }^{*} p<0.05,{ }^{* *} p<0.01,{ }^{* * *} p<0.001,{ }^{\text {ns }}$ non-significant $(p>0.05)$.

a Relative median change calculated based on the estimated annual concentration at the start $\left(y_{0}\right)$ and at the end $\left(y_{i}\right)$ of time series computed from the Sen's slope and intercept $\left(=100 \times\left[\left(y_{i}-y_{0}\right) / y_{0}\right]\right) .{ }^{\mathrm{b}} \mathrm{UK}$ emissions data from NAEI (2018).

stations) to control S pollution, reductions in energy production and manufacturing and the switch from coal to gas at the same time. Similar to trends in $\mathrm{NO}_{x}$ emission, the decreasing trend in $\mathrm{SO}_{2}$ emissions plateaued between 2009 and 2012 and then decreased again by a further $45 \%$ between 2012 and 2015 following the closure of a number of coal-fired power stations, as well as conversion of some coal-fired stations to burn biomass.

Over the same period, the network annual mean concentration decreased from $1.9 \mu \mathrm{g} \mathrm{SO} \mathrm{m}^{-3}$ in 2000 to $0.25 \mu \mathrm{g} \mathrm{SO}_{2} \mathrm{~m}^{-3}$ in 2015 (mean of 12 sites), continuing the long-term decline in $\mathrm{SO}_{2}$ concentrations observed at the background Eskdalemuir site (Sect. 3.1.3) and across the UK (ROTAP, 2012). The relative trends in $\mathrm{SO}_{2}$ emissions and concentrations tracked each other closely for all the time periods considered and it is clear that these decreases are highly correlated (Fig. 14). In the case of particulate $\mathrm{SO}_{4}^{2-}$ however, there is an apparent "gap" between emissions and concentrations in the trend normalized against the year 2000. Like $\mathrm{NO}_{3}^{-}$, re-analysis of the same annual data normalized against 2001 instead of 2000 takes the relative trend line for $\mathrm{SO}_{4}^{2-}$ closer to the trend lines in both $\mathrm{SO}_{2}$ emissions and concentrations (Fig. 14), thus again highlighting the potential bias in the use of a measured value at a specific time point in trend assessments when there is substantial inter-annual variability in the data.

From the MK trend analysis, the decrease in annual mean $\mathrm{SO}_{2}$ concentrations of $-81 \%(2000-2015, n=12)$, and $-60 \%$ (2006-2015, $n=30$ ) (Fig. 15, Table 4) are consistent with the substantial reduction of $-80 \%$ and $-64 \%$ in $\mathrm{SO}_{2}$ emissions over the two overlapping periods, respectively
(Table 5). The decrease in both emissions and concentrations $\mathrm{SO}_{2}$ is also almost twice as large as $\mathrm{HNO}_{3}$ (Table 5), illustrating the greater success in mitigating sulfur than nitrogen and the increasing dominance of $\mathrm{N}$ components in the atmosphere compared with $\mathrm{S}$, with larger decline in $\mathrm{SO}_{2}$ than $\mathrm{NO}_{x}$.

At the same time, the reduction in $\mathrm{SO}_{2}$ emission and measured concentration is accompanied by a smaller negative trend in particulate $\mathrm{SO}_{4}^{2-}$ (2000-2015: -69\% MK; 20062015: $-54 \% \mathrm{MK}$ ) (Table 5), with concentrations falling 3fold from an annual mean of $1.2 \mu \mathrm{gSO}_{4}^{2-} \mathrm{m}^{-3}$ in 2000 to $0.42 \mu \mathrm{g} \mathrm{SO}_{4}^{2-} \mathrm{m}^{-3}$ in 2015 . The smaller decrease in particulate $\mathrm{SO}_{4}^{2-}$ compared with its gaseous precursor, $\mathrm{SO}_{2}$, is similar to that observed at Eskdalemuir (Sect. 3.1.3). A similar picture is also seen in Europe, where atmospheric concentrations of gas phase $\mathrm{SO}_{2}$ decreased by about $92 \%$ compared with a smaller reduction of $65 \%$ in particulate $\mathrm{SO}_{4}^{2-}$ in response to sulfur emissions abatement over the 1990 2012 period in the EMEP region (EMEP, 2016). The ratio of $\mathrm{SO}_{2}: \mathrm{SO}_{4}^{2-}$ is also seen to show a decreasing trend over time (Fig. 16), with the largest change occurring between 2000 and 2006 that matches the period of largest decline in $\mathrm{SO}_{2}$ emissions.

Sea salt $\mathrm{SO}_{4}^{2-}$ (ss_SO $\mathrm{SO}_{4}$ ) aerosol, as discussed in Sect. 3.5, makes up a significant fraction of the total $\mathrm{SO}_{4}^{2-}$. It is possible that the smaller reduction in particulate $\mathrm{SO}_{4}^{2-}$, compared with $\mathrm{SO}_{2}$, may be explained by an underlying increase in the relative proportion of $\mathrm{ss}_{-} \mathrm{SO}_{4}$ to total $\mathrm{SO}_{4}^{2-}$. To assess the contribution of $\mathrm{ss}_{-} \mathrm{SO}_{4}$ to the observed trends in total $\mathrm{SO}_{4}^{2-}, \mathrm{ss}_{-} \mathrm{SO}_{4}$ concentrations (estimated according to 

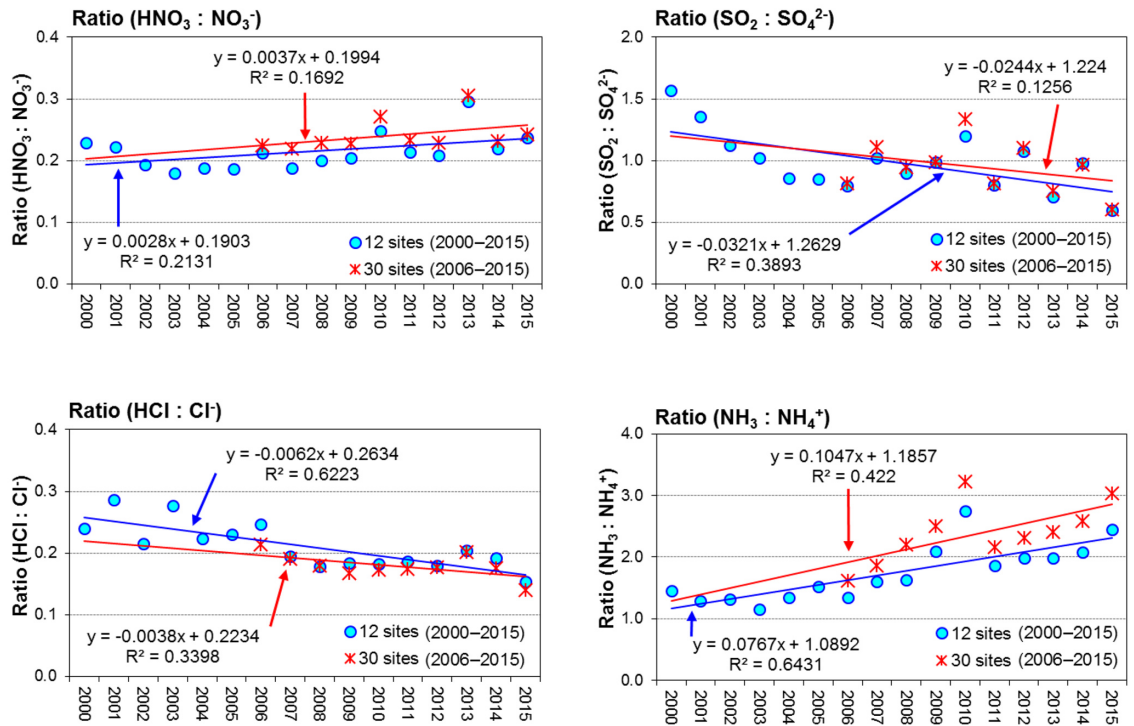

Figure 16. Long-term trends in the gas : aerosol ratio, from a comparison of the annual mean concentrations of 12 sites with complete time series from 2000 to 2015, and 30 sites with complete time series from 2006 to 2015, showing indicative differences in direction of trends in this ratio with time.

Equation (4) described in Sect. 3.5) and nss_SO $\mathrm{SO}_{4}^{-}$(=total $\left.\mathrm{SO}_{4}^{2-}-\mathrm{Ss}_{-} \mathrm{SO}_{4}\right)$ are compared with the long-term trends in total $\mathrm{SO}_{4}^{2-}$ in Fig. 17. Overall, there is no apparent trend in the long-term annual mean $\mathrm{ss}_{-} \mathrm{SO}_{4}$ data, with concentrations in range of 0.16 to $0.21 \mu \mathrm{gSO}_{4}^{2-}$. Since ss_ SO4 is derived from an empirical relationship with $\mathrm{Na}^{+}$(Sect. 3.5), the long-term trend data for $\mathrm{Na}^{+}$is also included in the analysis (Fig. 17). Similar to ss_SO ${ }_{4}$, there is no overall trend in the $\mathrm{Na}^{+}$data, with small inter-annual variability and annual mean concentrations in the range of $0.65-0.85 \mu \mathrm{g} \mathrm{Na}^{+} \mathrm{m}^{-3}$. ss_SO $\mathrm{SO}_{4}$ made up just $10 \%$ of the total $\mathrm{SO}_{4}^{2-}$ in 2000 , but by 2015, this had increased to just over $50 \%$ due to the decrease in nss_SO $\mathrm{SO}_{4}$ over that time. MK analysis of the nss_SO 4 (Table 4) showed decrease in concentrations of $-78 \%$ (2000 2015) and $-62 \%$ (2006-2015), similar to that observed in $\mathrm{SO}_{2}$ (-81\%: 2000-2015 and -60\%: 2006-2015), indicating a closer relationship between nss_. $\mathrm{SO}_{4}$ and $\mathrm{SO}_{2}$ than between total $\mathrm{SO}_{4}^{2-}$ and $\mathrm{SO}_{2}$.

\subsubsection{Trends in $\mathrm{HCl}$ and $\mathrm{Cl}^{-}$vs. $\mathrm{HCl}$ emissions}

$\mathrm{HCl}$ emissions in the $\mathrm{UK}$ also decreased substantially by $89 \%$ between 2000 and 2015, from 82 to $9 \mathrm{kt}$ in 2015 (NAEI, 2018), contrasting with a smaller, but non-significant decreasing trend in $\mathrm{HCl}$ concentrations (Figs. 14, 15, Table 5). The annual mean monitored concentrations in $\mathrm{HCl}$ over this period decreased from $0.30 \mu \mathrm{g} \mathrm{HCl} \mathrm{m}^{-3}$ in 2000 to $0.19 \mu \mathrm{g} \mathrm{HCl} \mathrm{m}{ }^{-3}$ in 2015. Most of the reduction in $\mathrm{HCl}$ emissions occurred before $2006(-79 \%$, from $82 \mathrm{kt}$ in 2000 to $17 \mathrm{kt}$ in 2006), with emissions plateauing since 2006 (NAEI, 2018) (Fig. 14). A corresponding decrease is not

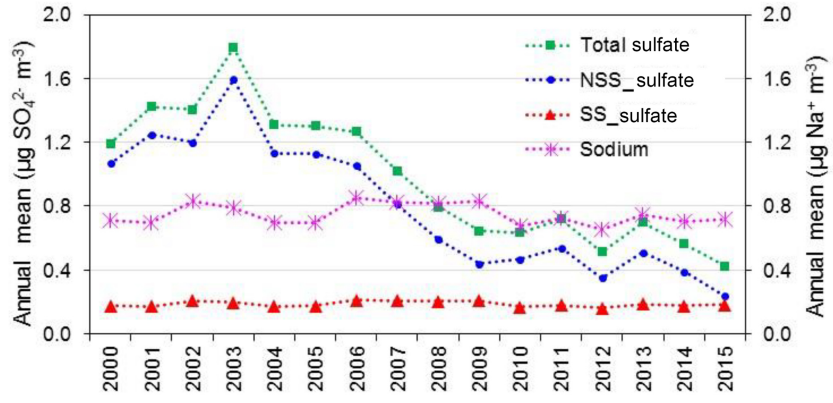

Figure 17. Comparison of long-term trends in annual mean concentrations of total sulfate (as determined from the amount of sulfate collected on the AGANet aerosol filter), nss_sulfate (estimated from the empirical relationship: [nss_SO $\left.\mathrm{SO}_{4}\right]=\left[\mathrm{SO}_{4}^{2-}\right]-\left(0.25 \times\left[\mathrm{Na}^{+}\right]\right)$, ss_sulfate (Total - nss) and sodium. Each data point represents the annually averaged mean concentration of 12 sites for the 16 year period from 2000 to 2015 .

seen in the $\mathrm{HCl}$ measurement data, where concentrations remained fairly stable at between $0.31 \mu \mathrm{g} \mathrm{m}^{-3} \mathrm{HCl}$ in 2000 to $0.33 \mu \mathrm{g} \mathrm{m}^{-3} \mathrm{HCl}$ in 2006. Since 2006 however, the relative change in $\mathrm{HCl}$ emissions is closely tracked by changes in concentrations of both the annual mean data from the original 12 sites and from the expanded 30 sites in the AGANet, with the small peak in $\mathrm{HCl}$ emissions in 2013 also captured in the annual mean data. This part of the time series therefore clearly shows a direct relationship between emissions and concentrations.

So why is the most significant fall in $\mathrm{HCl}$ emissions between 2000 and 2006 not captured by the network? $\mathrm{HCl}$ are 
mainly released as point sources. Coal burning, particularly from coal-fired power stations, is responsible for the majority of UK emissions: $92 \%$ in 1990 and $76 \%$ in 2015 , and reductions in $\mathrm{HCl}$ emissions in the UK inventory are largely as a result of declining coal use and the installation of emissions abatement measures at coal-fired power stations (implemented since 1993) aimed at reducing $S$ that also coincidentally reduced $\mathrm{HCl}$ emissions. It may be that a network of only 12 sites in the early periods failed to capture peak emissions and changes in source areas. While there is an indicative, but non-significant decreasing trend in $\mathrm{HCl}$ (2000-2015: $\mathrm{MK}=-28 \%, 2006-2015: \mathrm{MK}=-24 \%)$, no detectable trend in particulate $\mathrm{Cl}^{-}$can be seen (Table 4). Since $\mathrm{Cl}^{-}$is mainly associated with $\mathrm{Na}^{+}$(sea salt) in the AGANet measurements (Sect. 3.5), the absence of a trend in $\mathrm{Cl}^{-}$(Fig. 15) and $\mathrm{Na}^{+}$(Sect. 3.8.2, Fig. 17) provides evidence of a constant background in sea salt in the UK atmosphere.

\subsubsection{Trends in $\mathrm{NH}_{3}$ and $\mathrm{NH}_{4}^{+}$vs. $\mathrm{NH}_{3}$ emissions}

In comparison to the acid gases, there is a more modest decrease of $-9 \%$ in $\mathrm{NH}_{3}$ emissions, from $254 \mathrm{kt} \mathrm{NH}_{3}$ in 2000 to $231 \mathrm{kt} \mathrm{NH}_{3}$ in 2015 (NAEI, 2018). This is smaller than the decrease seen in the annually averaged $\mathrm{NH}_{3}$ concentrations at the 12 AGANet sites (2000-2015: -30\% MK) over the same period (Figs. 14, 15, Table 5). A recent assessment by Tang et al. (2018) showed that $\mathrm{NH}_{3}$ trends are highly dependent on site selection and categorization of sites in the analysis. A more comprehensive analysis of a larger number of sites shows smaller reductions over time, whereas a significant decreasing trend in $\mathrm{NH}_{3}$ concentrations was observed in the grouped analysis of sites in areas classed as dominated by pig and poultry emissions, contrasting with an upward (non-significant) trend for sites in cattle-dominated areas. Therefore there is a large degree of uncertainty in interpreting the trends in $\mathrm{NH}_{3}$ concentrations from a subset of just 12 sites, since $\mathrm{NH}_{3}$ emissions are dominated by agricultural emissions ( $>80 \%$ ) that vary hugely on a local to regional scale across the UK.

At the same time, there is a larger decrease in particulate $\mathrm{NH}_{4}^{+}$concentrations $(-62 \% \mathrm{MK})$, contrasting with the smaller decrease in $\mathrm{NH}_{3}$ concentrations over the period 2010-2015 (-30\% MK) (Table 4), with the $\mathrm{NH}_{3}: \mathrm{NH}_{4}^{+}$ratio also increasing with time (Fig. 16). This provides evidence for a shift in partitioning from the particulate phase $\mathrm{NH}_{4}^{+}$to the gaseous phase $\mathrm{NH}_{3}$ in the UK data, discussed in Tang et al. (2018). The change in partitioning from particulate $\mathrm{NH}_{4}^{+}$to gaseous $\mathrm{NH}_{3}$ is also occurring in other parts of Europe, where decreases in $\mathrm{NH}_{3}$ concentrations have been smaller than emission trends would suggest, due to large decreases in $\mathrm{SO}_{2}$ emissions (Bleeker et al., 2009; Horvath et al., 2009).

\subsubsection{Changes in UK chemical climate}

Atmospheric $\mathrm{SO}_{2}$ concentrations in the $\mathrm{UK}$ has declined to very low levels over the 16 years of measurements in AGANet, with annual mean concentrations in 2015 $\left(0.25 \mu \mathrm{g} \mathrm{SO}_{2} \mathrm{~m}^{-3}, n=12\right)$ approaching that of the other acid gases $\mathrm{HNO}_{3}\left(0.21 \mu \mathrm{g} \mathrm{HNO}_{3} \mathrm{~m}^{-3}, n=12\right)$ and $\mathrm{HCl}$ $\left(0.20 \mu \mathrm{g} \mathrm{HCl} \mathrm{m}^{-3}, n=12\right) . \mathrm{NH}_{3}$ measured at the same time at the AGANet sites also decreased, but to a smaller extent, to a mean concentration of $1.0 \mu \mathrm{g} \mathrm{NH}_{3} \mathrm{~m}^{-3}(n=12)$ in 2015 . The changes in measured concentrations of $\mathrm{SO}_{2}, \mathrm{HNO}_{3}, \mathrm{HCl}$ and $\mathrm{NH}_{3}$ are consistent with the estimated decrease in emissions of $\mathrm{SO}_{2}, \mathrm{NO}_{x}, \mathrm{HCl}$, and $\mathrm{NH}_{3}$ since $2000 . \mathrm{SO}_{2}$ is therefore no longer the dominant acid gas, with $\mathrm{HNO}_{3}$ and $\mathrm{HCl}$ together contributing a larger fraction of the total acidity in the UK atmosphere.

Past studies have shown that the increasing ratio of $\mathrm{NH}_{3}$ to $\mathrm{SO}_{2}$ in the atmosphere leads to increased dry deposition of $\mathrm{SO}_{2}$, accelerating the decrease in atmospheric $\mathrm{SO}_{2}$ concentrations than would be achieved by emissions reduction alone (Fowler et al., 2001, 2009; ROTAP 2012). The dry deposition of $\mathrm{SO}_{2}$ and $\mathrm{NH}_{3}$, by uptake of the gases in a liquid film on leave surfaces, are known to be enhanced when both gases are present in a process termed "co-deposition" (Fowler et al., 2001). Where ambient $\mathrm{NH}_{3}$ concentrations exceed that of $\mathrm{SO}_{2}$, there is enough $\mathrm{NH}_{3}$ to neutralize acidity in the liquid film and oxidize deposited $\mathrm{SO}_{2}$, and maintain large rates of deposition of $\mathrm{SO}_{2}$. With changes in the relative concentrations of acid gases in the UK and across Europe however, the deposition rates will increasingly be controlled by the $\mathrm{NH}_{3}$ / combined acidity (sum of $\mathrm{SO}_{2}, \mathrm{HNO}_{3}$ and $\mathrm{HCl}$ ) molar ratio, rather than based on $\mathrm{SO}_{2}$ alone (Fowler et al., 2009).

To look at the UK situation, an analysis of the molar ratios of $\mathrm{NH}_{3}$ to acid gases is presented in Fig. 18a. The molar ratio of $\mathrm{NH}_{3}$ to acid gases (sum of $\mathrm{SO}_{2}, \mathrm{HNO}_{3}$ and $\mathrm{HCl}$ ) increased with time, from 1.9 in 2000 to 4.7 in 2015, confirming that $\mathrm{NH}_{3}$ is increasingly in molar excess over atmospheric acidity. The ratio of annual mean concentrations of $\mathrm{NH}_{3}\left(80 \mathrm{nmol} \mathrm{m}^{-3}\right)$ to $\mathrm{SO}_{2}\left(29 \mathrm{nmol} \mathrm{m}^{-3}\right)$ was 2.7 in 2000 . By 2015, this ratio had increased to 15 (annual mean concentrations of $\mathrm{NH}_{3}=58 \mathrm{nmol} \mathrm{m}^{-3}$ cf. $\mathrm{SO}_{2}=$ $\left.4 \mathrm{nmol} \mathrm{m}^{-3}\right)$. Molar concentrations of $\mathrm{HNO}_{3}\left(4 \mathrm{nmol} \mathrm{m}^{-3}\right)$ and $\mathrm{HCl}\left(6 \mathrm{nmol} \mathrm{m}^{-3}\right)$ were comparable to $\mathrm{SO}_{2}$ in 2015 , highlighting the increasing importance of $\mathrm{HNO}_{3}$ and $\mathrm{HCl}$ in contributing to atmospheric acidity. A larger decrease in $\mathrm{SO}_{2}$ $(-81 \%)$ than particulate sulfate $(-69 \%)$ in the AGANet data (Table 4) would appear at first to suggest that the large $\mathrm{NH}_{3}: \mathrm{SO}_{2}$ ratio is contributing to a more rapid decrease in $\mathrm{SO}_{2}$ concentrations. However, when the sea salt fraction of $\mathrm{SO}_{4}^{2-}$ is removed from the sulfate trend (Sect. 3.8.2), the decrease in nss_SO $\mathrm{SO}_{4}(-78 \%)$ is similar to $\mathrm{SO}_{2}(-81 \%)$ (Table 4). Since the decreasing trend in the ratio of $\mathrm{SO}_{2}$ to $\mathrm{SO}_{4}^{2-}$ also appeared to stabilize after 2006 (Sect. 3.8.2), this would suggest that maximum deposition rates for $\mathrm{SO}_{2}$ may 

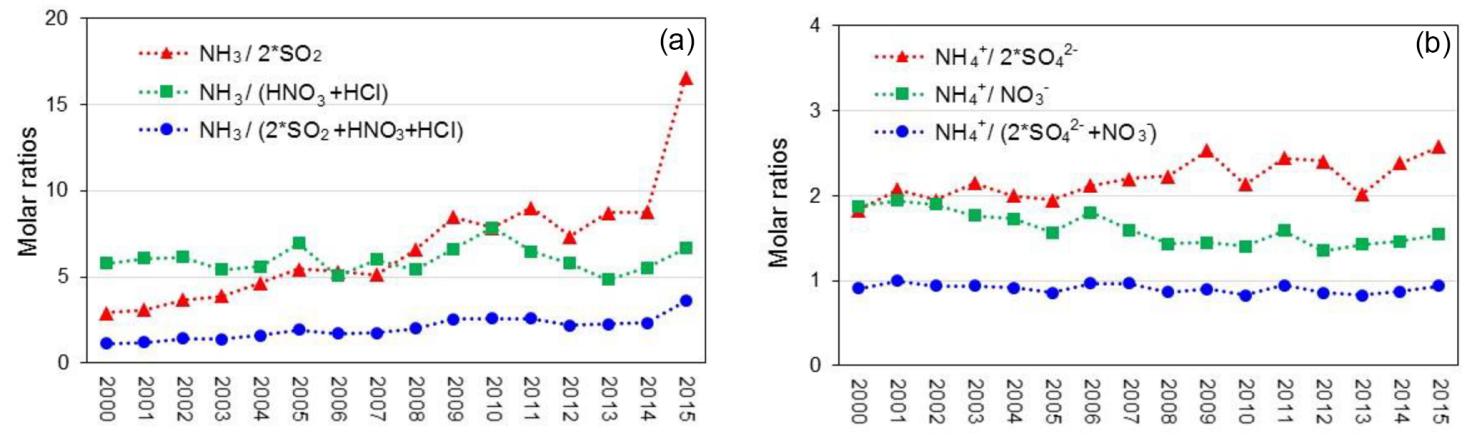

Figure 18. Long-term changes between 2000 and 2015 in (a) molar ratio of $\mathrm{NH}_{3}$ to acid gases $\left(\mathrm{SO}_{2}, \mathrm{HNO}_{3}\right.$, and $\left.\mathrm{HCl}\right)$ and (b) molar ratio of particulate $\mathrm{NH}_{4}^{+}$to acid aerosols $\left(\mathrm{SO}_{4}^{2-}\right.$ and $\left.\mathrm{NO}_{3}^{-}\right)$from measurements made at 12 sites in AGANet.

have been reached with the smaller $\mathrm{SO}_{2}$ concentrations since 2006.

The substantial decrease in $\mathrm{UK} \mathrm{SO}_{2}$ emissions and concentrations, while $\mathrm{UK} \mathrm{NO}_{x}$ emissions and concentrations remain relatively high in comparison, set against a much smaller decrease in $\mathrm{NH}_{3}$ emissions and concentrations since 2000 is leading to changes in the respective particulate $\mathrm{SO}_{4}^{2-}$, $\mathrm{NO}_{3}^{-}$and $\mathrm{NH}_{4}^{+}$concentrations. Since the affinity of $\mathrm{H}_{2} \mathrm{SO}_{4}$ (oxidation product of $\mathrm{SO}_{2}$ ) for $\mathrm{NH}_{3}$ is much larger than that of $\mathrm{HNO}_{3}$ and $\mathrm{HCl}$, available $\mathrm{NH}_{3}$ is first taken up by $\mathrm{H}_{2} \mathrm{SO}_{4}$ to form ammonium sulfate compounds $\left(\mathrm{NH}_{4} \mathrm{HSO}_{4}\right.$ and $\left.\left(\mathrm{NH}_{4}\right)_{2} \mathrm{SO}_{4}\right)$, with any excess $\mathrm{NH}_{3}$ then available to react with $\mathrm{HNO}_{3}$ and $\mathrm{HCl}$ to form $\mathrm{NH}_{4} \mathrm{NO}_{3}$ and $\mathrm{NH}_{4} \mathrm{Cl}$. Analysis of the different particulate components in Sect. 3.5 showed that the ammonium aerosols are mainly made up of $\left(\mathrm{NH}_{4}\right)_{2} \mathrm{SO}_{4}$ and $\mathrm{NH}_{4} \mathrm{NO}_{3}$. With the large reduction in $\mathrm{SO}_{2}$, more $\mathrm{NH}_{3}$ is available to react with $\mathrm{HNO}_{3}$ to form $\mathrm{NH}_{4} \mathrm{NO}_{3}$ and concentrations of $\mathrm{NH}_{4}^{+}$and $\mathrm{NO}_{3}^{-}$are now observed to be in molar excess over $\mathrm{SO}_{4}^{2-}$, providing evidence of a change in the particulate phase from $\left(\mathrm{NH}_{4}\right)_{2} \mathrm{SO}_{4}$ to $\mathrm{NH}_{4} \mathrm{NO}_{3}$ (Fig. 18b).

A change to an $\mathrm{NH}_{4} \mathrm{NO}_{3}$ rich atmosphere and the potential for $\mathrm{NH}_{4} \mathrm{NO}_{3}$ to release $\mathrm{NH}_{3}$ and $\mathrm{HNO}_{3}$ in warm weather, together with the surfeit of $\mathrm{NH}_{3}$ also means that a larger fraction of the reduced and oxidized $\mathrm{N}$ is remaining in the gas phase as $\mathrm{NH}_{3}$ and $\mathrm{HNO}_{3}$. An increased partitioning to the gas phase may account for the larger decrease in particulate $\mathrm{NH}_{4}^{+}(\mathrm{MK}-62 \%$ between 2000 and 2015, $n=12)$ and $\mathrm{NO}_{3}^{-}(\mathrm{MK}-52 \%$ between 2000 and 2015, $n=12)$ than $\mathrm{NH}_{3}(\mathrm{MK}-30 \%$ between 2000 and 2015, $n=12), \mathrm{HNO}_{3}$ (MK $-45 \%$ between 2000 and 2015, $n=12$ ) (Table 4) and the increase in gas to aerosol ratios $\left(\mathrm{NH}_{3}: \mathrm{NH}_{4}^{+}\right.$and $\mathrm{HNO}_{3}$ : $\mathrm{NO}_{3}^{-}$) over the 16 year period (Fig. 16). A higher concentration of the gas-phase $\mathrm{NH}_{3}$ and $\mathrm{HNO}_{3}$ may therefore be maintained in the atmosphere than expected on the basis of the emissions trends in $\mathrm{NH}_{3}$ and $\mathrm{NO}_{x}$. Given the larger deposition velocities of $\mathrm{NH}_{3}$ and $\mathrm{HNO}_{3}$ compared to aerosols, more of the $\mathrm{NH}_{3}$ and $\mathrm{HNO}_{3}$ emitted will have the potential to deposit more locally with a smaller footprint within the UK.
Currently, the critical loads of acidity (sulfur and nitrogen) are exceeded by $44 \%$ of the area of sensitive habitats in the UK (based on mean deposition data for 20122014), whereas the figure for exceedance of eutrophication (nutrient nitrogen) is even larger, at $62 \%$ (based on deposition data for 2012-2014) (Hall and Smith, 2016). Air quality policies have been very successful in abating $\mathrm{SO}_{2}$ emissions (-80\%: 2000-2015) and moderately successful with $\mathrm{NO}_{x}$ emissions ( $-58 \%$ : 2000-2015), with both on course to meet the emission reduction targets set out under the 2012 Gothenburg protocol and 2016 NECD. Difficulties in abating $\mathrm{NH}_{3}$ is reflected in the smaller reduction in $\mathrm{NH}_{3}$ emissions (-9\%: 2000-2015), with emissions increasing, rather than decreasing since 2013 and it is likely that abatement measures may be required to meet emission reduction targets. In recognizing the need to tackle the ammonia problem, the Code of Good Agricultural Practice (COGAP) was published under the UK government's Clean Air Strategy (launched in July 2018) as a step towards reducing $\mathrm{NH}_{3}$ emissions from agriculture.

Based on the current emission trends and evidence from AGANet and NAMN long-term measurements, atmospheric $\mathrm{N}$ deposition from oxidized $\mathrm{N}\left(\mathrm{NO}_{x}, \mathrm{HNO}_{3}\right.$ and $\left.\mathrm{NO}_{3}^{-}\right)$and from reduced $\mathrm{N}\left(\mathrm{NH}_{3}, \mathrm{NH}_{4}^{+}\right)$are likely to continue to exceed critical loads of $\mathrm{N}$ deposition over large areas of sensitive habitats, with implications for UK's commitment to maintain or restore natural habitats (e.g. Natura 2000 sites; Hallsworth et al., 2010) to a favourable conservation status under the EU Habitats Directive (Council Directive 92/43/EEC) and ecosystem monitoring under Article 9 and Annex V of Directive 2016/2284 (NECD). The changes are also relevant for human health effects assessment, since $\mathrm{NH}_{4} \mathrm{NO}_{3}$ and $\left(\mathrm{NH}_{4}\right)_{2} \mathrm{SO}_{4}$ are mainly in the fine mode and constitute a significant fraction of $\mathrm{PM}_{2.5}$ that are associated with acute and chronic human health problems. The change in partitioning from $\left(\mathrm{NH}_{4}\right)_{2} \mathrm{SO}_{4}$ to $\mathrm{NH}_{4} \mathrm{NO}_{3}$, coupled to import of $\mathrm{NH}_{4} \mathrm{NO}_{3}$ from long-range transport (driven by emissions of $\mathrm{NH}_{3}$ and $\mathrm{NO}_{x}$ from outside the UK) poses policy challenges in protection of human health from effects of air pollution, 
particularly in urban areas where concentrations of the $\mathrm{PM}_{2.5}$ precursor gases $\mathrm{NO}_{x}, \mathrm{SO}_{2}$ and $\mathrm{NH}_{3}$ are higher.

\section{Conclusions}

The UK Acid Gases and Aerosol network (AGANet) is delivering, uniquely, a comprehensive UK long-term dataset of speciated acid gases $\left(\mathrm{HNO}_{3}, \mathrm{SO}_{2}, \mathrm{HCl}\right)$ and aerosol components $\left(\mathrm{NO}_{3}^{-}, \mathrm{SO}_{4}^{2-}, \mathrm{Cl}^{-}, \mathrm{Na}^{+}, \mathrm{Ca}^{2+}, \mathrm{Mg}^{2+}\right)$ and also of $\mathrm{NH}_{3}$ and $\mathrm{NH}_{4}^{+}$measured within the National Ammonia Monitoring Network (NAMN). Speciated measurements are made with an established low-cost DELTA denuder-filter pack methodology, allowing assessment of atmospheric chemical composition and gas-aerosol phase interactions. Other manual denuder-filter implementations designed for high timeresolution measurements are useful at selected locations for detailed analysis and model testing, but they are resource intensive and expensive. The DELTA monthly measurements on the other hand are cost-efficient for estimating annual mean concentrations, providing sufficient resolution for analysis of temporal trends, and which can be operated at a large number of sites in the network to provide long-term trends and temporal and spatial patterns.

Large regional patterns in concentrations are observed, with the largest concentrations of $\mathrm{HNO}_{3}, \mathrm{SO}_{2}$, and aerosol $\mathrm{NO}_{3}^{-}$and $\mathrm{SO}_{4}^{2-}$ in southern and eastern England, attributed to anthropogenic (combustion, vehicular) and long-range transboundary sources from Europe, and smallest in western Scotland and Northern Ireland. $\mathrm{HCl}$ concentrations are also largest in the south-eastern, south-western and central England, attributed to dual contribution from anthropogenic (coal combustion) and marine sources (reaction of sea salt with $\mathrm{HNO}_{3}$ and $\mathrm{H}_{2} \mathrm{SO}_{4}$ to form $\mathrm{HCl}$ ). For $\mathrm{Cl}^{-}$, this has a similar spatial distribution as $\mathrm{Na}^{+}$, with the highest concentrations at coastal sites, reflecting their origin from marine sources (sea salt).

Distinctive temporal trends are established for the different components, with the seasonal variability influenced by local to regional emissions, climate, meteorology and photochemistry. A weak seasonal cycle is observed in $\mathrm{HNO}_{3}$, with slightly higher concentrations in late winter and early spring, due to formation from photochemical production processes. Particulate $\mathrm{NO}_{3}^{-}$and $\mathrm{SO}_{4}^{2-}$ have highest concentrations in spring, coinciding with the peak in concentrations of $\mathrm{NH}_{3}$ and $\mathrm{NH}_{4}^{+}$, and are therefore likely to be attributed to formation of $\mathrm{NH}_{4} \mathrm{NO}_{3}$ and $\left(\mathrm{NH}_{4}\right)_{2} \mathrm{SO}_{4}$ from reaction with a surplus of higher concentrations of $\mathrm{NH}_{3}$ at that time of year. Conversely, peak concentrations of $\mathrm{SO}_{2}, \mathrm{Na}^{+}$, and $\mathrm{Cl}^{-}$occur during winter, likely from combustion processes (heating) for $\mathrm{SO}_{2}$ and marine sources in winter (more stormy weather) for sea salt generation. Magnesium is a crustal element, but which is also present in sea salt aerosols. The seasonal trend in $\mathrm{Mg}^{2+}$ is similar to $\mathrm{Na}^{+}$, with maxima during winter and minima in summer; therefore some of the sea salt aerosol may be in the form of $\mathrm{MgCl}_{2}$.

Enhancement of local to regional concentrations of reactive gases and aerosols in the UK from long-range transboundary transport of pollutants into the UK is highlighted by two pollution events, captured in the long-term AGANet monthly measurements. In 2003, a spring episode with elevated concentrations of $\mathrm{HNO}_{3}$ and $\mathrm{NO}_{3}^{-}$was driven by meteorology, with easterly winds transporting $\mathrm{NH}_{4} \mathrm{NO}_{3}$ formed in Europe into the UK and a high pressure system over the UK (February-April) that led to a build-up of $\mathrm{NH}_{4} \mathrm{NO}_{3}$ and $\mathrm{HNO}_{3}$ concentrations from both local and transboundary sources. A second, but smaller episode of elevated concentrations of $\mathrm{SO}_{2}$ and $\mathrm{HNO}_{3}$, as well as of particulate $\mathrm{SO}_{4}^{2}$, $\mathrm{NO}_{3}^{-}$, and $\mathrm{NH}_{4}^{+}$, in September 2014 was shown to be from transport of pollutant plume from the Icelandic Holuhraun volcanic eruptions at that time.

After more than 16 years of operation, the AGANet is also capturing important long-term changes in the concentrations and partitioning between gas and aerosol of the $\mathrm{N}$ and $\mathrm{S}$ components in the atmosphere. A significant decrease of $-81 \%$ (MK) in annual mean concentrations of $\mathrm{SO}_{2}$ between 2000 and 2015 was in agreement with the estimated $-80 \%$ reduction in $\mathrm{SO}_{2}$ emissions, but larger than the accompanying decline in particulate $\mathrm{SO}_{4}^{2-}(-69 \% \mathrm{MK})$. A more modest reduction in $\mathrm{HNO}_{3}(-45 \% \mathrm{MK})$ and particulate $\mathrm{NO}_{3}^{-}$ $(-52 \% \mathrm{MK})$ are consistent with the estimated $58 \%$ decline in $\mathrm{NO}_{x}$ emissions over this same period. The decrease in particulate $\mathrm{NH}_{4}^{+}(-62 \% \mathrm{MK})$ is larger than the precursor gas $\mathrm{NH}_{3}(2000-2015=-30 \% \mathrm{MK} / \mathrm{LR})$ and larger than the estimated decline in estimated $\mathrm{NH}_{3}$ emissions of $9 \%$. However, it should be noted that $\mathrm{NH}_{3}$ trends are highly dependent on site selection according to an earlier assessment made on a more comprehensive dataset from the UK NAMN.

The substantial decrease in $\mathrm{UK} \mathrm{SO}_{2}$ emissions and concentrations, while $\mathrm{UK} \mathrm{NO}_{x}$ emissions and concentrations $\left(\mathrm{HNO}_{3}\right)$ remain relatively high in comparison, set against a much smaller decrease in $\mathrm{NH}_{3}$ emissions and concentrations since 2000 is leaving more $\mathrm{NH}_{3}$ available to react with $\mathrm{HNO}_{3}$ to form the semi-volatile particulate $\mathrm{NH}_{4} \mathrm{NO}_{3}$. Particulate $\mathrm{NH}_{4}^{+}$and $\mathrm{NO}_{3}^{-}$are now in molar excess over $\mathrm{SO}_{4}^{2-}$, providing evidence of a shift in the particulate phase from $\left(\mathrm{NH}_{4}\right)_{2} \mathrm{SO}_{4}$ to $\mathrm{NH}_{4} \mathrm{NO}_{3}$. A change to an $\mathrm{NH}_{4} \mathrm{NO}_{3}$ rich atmosphere and the potential for $\mathrm{NH}_{4} \mathrm{NO}_{3}$ to release $\mathrm{NH}_{3}$ and $\mathrm{HNO}_{3}$ in warm weather, together with the surfeit of $\mathrm{NH}_{3}$ also means that a larger fraction of the reduced and oxidized $\mathrm{N}$ is remaining in the gas phase as $\mathrm{NH}_{3}$ and $\mathrm{HNO}_{3}$. The change in partitioning from particulate $\mathrm{NH}_{4}^{+}$to gaseous $\mathrm{NH}_{3}$ is also occurring in other parts of Europe, where decreases in $\mathrm{NH}_{3}$ concentrations have been smaller than emission trends would suggest, due to successful mitigation in $\mathrm{SO}_{2}$ emissions. Higher concentrations of the $\mathrm{NH}_{3}$ and $\mathrm{HNO}_{3}$ in the atmosphere will deposit more locally, exacerbating the effects of local $\mathrm{N}$ deposition loads over large areas of sensitive habitats, with implications for UK's commitment to 
maintain or restore natural habitats (e.g. Natura 2000 sites) to a favourable conservation status under the EU Habitats Directive (Council Directive 92/43/EEC) and ecosystem monitoring under Article 9 and Annex V of Directive 2016/2284 (NECD). The changes are also important in terms of human effects assessment since $\mathrm{NH}_{4} \mathrm{NO}_{3}$ constitute a significant fraction of $\mathrm{PM}_{2.5}$ that are implicated in acute and chronic human health effects and linked to increased mortality from respiratory and cardiopulmonary diseases.

Data availability. Ratified data from the Acid Gases and Aerosol Network (AGANet) and the National Ammonia Monitoring Network (NAMN) are publically accessible on the Defra UK-AIR website (https://uk-air.defra.gov.uk/data, last access: 30 March 2018).

Supplement. The supplement related to this article is available online at: https://doi.org/10.5194/acp-18-16293-2018-supplement.

Author contributions. MAS conceived and proposed the establishment of the NAMN and AGANet. MAS and YST developed the methods (ALPHA and DELTA) and set up the NAMN and AGANet. UD assisted in building the DELTA equipment and conducting the DELTA vs. ADS intercomparison during the initial phase. IS assisted in designing, building, and installing DELTA equipment for the expanded AGANet. CFB provided resources and coordinated and managed the UKEAP network. CC and KV coordinated and managed the Precip-net and NO2-net and also the former ADMN networks. YST, IS, NvD, and CC organized and carried out UKEAP network site servicing. YST, NvD, JP, ST, MP, POK, and HC performed the sample preparation and chemical analyses. POK and AL supervised and performed quality checks on chemistry analyses. MGP provided resources and managed and coordinated chemistry analyses. DL carried out data curation and designed the $\mathrm{CEH}$ AAGA database for NAMN and AGANet data. KV was involved in producing and maintaining the Defra UK-AIR website. YST coordinated and managed the NAMN and AGANet (1997-2016), performed the data collection, data analysis, and wrote the paper. MS, $\mathrm{MRH}, \mathrm{CFB}, \mathrm{UD}, \mathrm{NvD}$, and $\mathrm{KV}$ provided input on the paper.

Competing interests. The authors declare that they have no conflict of interest.

Acknowledgements. The UK AGANet and NAMN are funded by the Department for Environment, Food and Rural Affairs (Defra) and the devolved administrations, under the UK Acid Deposition Monitoring Network (ADMN: 1999-2008) and UK Eutrophying and Acidifying Atmospheric Pollutants network (UKEAP: 2009-present). This work was also supported by other NERC $\mathrm{CEH}$ programmes, including the Natural Environment Research Council award number NE/R016429/1 as part of the UK-SCaPE programme delivering National Capability. The authors gratefully acknowledge assistance and contributions from the following groups: the large numbers of dedicated local site operators without whom the monitoring work would not be possible, site owners for provision of facilities, Harwell Scientifics Laboratory (now Environmental Scientifics Group (ESG) Ltd) for provision of chemical analysis for the AGANet between 1999 to 2009, the Centralised Analytical Chemistry facility in Lancaster (in particular Heather Carter, Darren Sleep and Philip Rowland) for sample preparation and chemical analysis since 2009, and colleagues at both CEH Edinburgh (Robert Storeton-West, Linda Love, Sarah Leeson, Matt Jones, Chris Andrews, Amy Stephens, Margaret Anderson, Ian D. Leith) and Ricardo Energy \& Environment field team (Martin Davies, Tim Bevington, Ben Davies, Chris Colbeck) for assisting in site and equipment maintenance and data collection.

Edited by: Annmarie Carlton

Reviewed by: Chris Flechard and one anonymous referee

\section{References}

Aas, W., Carou, S., Alebic-Juretic, A., Aneja, V. P., Balasubramanian, R., Berge, H., Cape, J. N., Delon, C., Denmead, O. T., Dennis, R. L., Dentener, F., Dore, A. J., Du, E., Forti, M. C., GalyLacaux, C., Geupel, M., Haeuber, R., Iacoban, C., Komarov, A. S., Kubin, E., Kulshrestha, U. C., Lamb, B., Liu, X., Patra, D. D., Pienaar, J. J., Pinho, P., Rao, P. S. P., Shen, J., Sutton, M. A., Theobald, M. R., Vadrevu, K. P., and Vet, R.: Progress in nitrogen deposition monitoring and modelling, in: Nitrogen deposition, critical loads and biodiversity, edited by: Sutton, M. A., Mason, K. E., Sheppard, L. J., Sverdrup, H., Haeuber, R., and Hicks, W. K., Dordrecht, Springer, 455-463, 2014.

Allegrini, I., De Santis, F., Di Palo, V., Febo, A., Perrino, C., Possanzini, M., and Liberti, A.: Annular denuder method for sampling reactive gases and aerosols in the atmosphere, Sci. Total Environ., 67, 1-16, https://doi.org/10.1016/00489697(87)90062-3, 1987.

Aneja, V. P., Roelle, P. A., Murray, G. C., Southerland, J., Erisman, J. W., Fowler, D., Asman, W. A. H., and Patni N.: Atmospheric nitrogen compounds II: emissions, transport, transformation, deposition and assessment, Atmos. Environ., 35, 1903-1911, 2001. Ayers, G. P., Gillett, R. W., Cainey, J. M., and Dick, A. L.: Chloride and Bromide Loss from Sea salt Particles in Southern Ocean Air, J. Atmos. Chem., 33, 299-319, https://doi.org/10.1023/A:1006120205159, 1999.

AQEG: Ozone in the United Kingdom, Air Quality Expert Group report, Department for Environment, Food and Rural Affairs, Scottish Executive, Welsh Government, Department of the Environment in Northern Ireland, available at: https://uk-air.defra. gov.uk/assets/documents/reports/aqeg/aqeg-ozone-report.pdf (last access: 25 March 2017), 2009.

AQEG: Fine Particulate Matter $\left(\mathrm{PM}_{2.5}\right)$ in the United Kingdom, Air Quality Expert Group report, Department for Environment, Food and Rural Affairs, Scottish Executive, Welsh Government, Department of the Environment in Northern Ireland, available at: https://uk-air.defra.gov.uk/assets/documents/reports/cat11/ 1212141150_AQEG_Fine_Particulate_Matter_in_the_UK.pdf (last access: 25 March 2017), 2012.

AQEG: Linking Emission Inventories and Ambient Measurements, Air Quality Expert Group report, Department for Environment, Food and Rural Affairs, Scottish Executive, Welsh Government, 
Department of the Environment in Northern Ireland, available at: https://uk-air.defra.gov.uk/assets/documents/reports/ cat11/1508060906_DEF-PB14106_Linking_Emissions_ Inventories_And_Ambient_Measurements_Final.pdf access: 25 March 2017), 2013a.

AQEG: Mitigation of United Kingdom $\mathrm{PM}_{2.5}$ Concentrations, Air Quality Expert Group report, Department for Environment, Food and Rural Affairs, Scottish Executive, Welsh Government, Department of the Environment in Northern Ireland, available at: https://uk-air.defra.gov.uk/assets/documents/reports/cat11/ 1508060903_DEF-PB14161_Mitigation_of_UK_PM25.pdf (last access: 25 March 2017), 2013b.

Bai, H., Chungsying, L., Chang, K.-F., and Fang, G.-C.: Sources of sampling error for field measurement of nitric acid gas by a denuder system, Atmos. Environ., 37, 941-947, https://doi.org/10.1016/S1352-2310(02)00972-x, 2003

Bleeker, A., Sutton, M. A., Acherman, B., Alebic-Juretic, A., Aneja, V. P., Ellermann, T., Erisman, J. W., Fowler, D., Fagerli, H., Gauger, T., Harlen, K. S., Hole, L. R., Horvath, L., Mitosinkova, M., Smith, R. I., Tang, Y. S., and van Pul, A.: Linking Ammonia Emission Trends to Measured Concentrations and Deposition of Reduced Nitrogen at Different Scales, in: Atmospheric Ammonia - Detecting Emission Changes and Environmental Impacts, edited by: Sutton, M. A., Reis, S., and Baker, S. M. H., Springer Netherlands, 123-180, 2009.

Bobbink, R., Hicks, K., Galloway, J., Spranger, T., Alkemade, R., Ashmore, M., Bustamante, M., Cinderby, S., Davidson, E., Dentener, F., Emmett, B., Erisman, J.-W., Fenn, M., Gilliam, F., Nordin, A., Pardo, L., and De Vries, W.: Global assessment of nitrogen deposition effects on terrestrial plant diversity: a synthesis, Ecol. Appl., 20, 30-59, https://doi.org/10.1890/08-1140.1, 2010.

Bower, K. N., Choularton, T. W., Gallagher, M. W., Colvile, R. N., Wells, M., Beswick, K. M., Wiedensohler, A., Hansson, H.C., Svenningsson, B., Swietlicki, E., Wendisch, M., Berner, A., Kruisz, C., Laj, P., Facchini, M. C., Fuzzi, S., Bizjak, M., Dollard, G., Jones, B., Acker, K., Wieprecht, W., Preiss, M., Sutton, M. A., Hargreaves, K. J., Storeton-West, R. L., Cape, J. N., and Arends, B. G.: Observations and modelling of the processing of aerosol by a hill cap cloud, Atmos. Environ., 31, 2527-2544, 1997.

Bull, K. R.: The critical loads/levels approach to gaseous pollutant emission control, Environ. Poll., 69, 105-123, https://doi.org/10.1016/0269-7491(91)90137-L, 1991.

Bull, K. R.: Critical loads - Possibilities and constraints, Water Air Soil Poll., 85, 201-212, https://doi.org/10.1007/bf00483701, 1995.

Bytnerowicz, A., Sanz, M. J., Arbaugh, M. J., Padgett, P. E., Jones, D. P., and Davila, A.: Passive sampler for monitoring ambient nitric acid $\left(\mathrm{HNO}_{3}\right)$ and nitrous acid $\left(\mathrm{HNO}_{2}\right)$ concentrations, Atmos. Environ., 39, 2655-2660, https://doi.org/10.1016/j.atmosenv.2005.01.018, 2005.

Cape, J. N., van der Eerden, L. J., Sheppard, L. J., Leith, I. D., and Sutton, M. A.: Evidence for changing the Critical Level for ammonia, Environ. Poll., 157, 1033-1037, https://doi.org/10.1016/j.envpol.2008.09.049, 2009.

Chatfield, C.: The analysis of time series: an introduction, CRC press, 2016.
Chemel, C., Sokhi, R. S., Yu, Y., Hayman, G. D., Vincent, K. J., Fore, A. J., Tang, Y. S., Prain, H. D., and Fisher, B. E. A.: Evaluation of a CMAQ simulation at high resolution over the UK for the calendar year 2003, Atmos. Environ., 44, 2927-2939, https://doi.org/10.1016/j.atmosenv.2010.03.029, 2010.

Cheng, Y., Duan, F.-K., He, K.-B., Du, Z.-Y., Zheng, M., and Ma, Y.-L.: Sampling artifacts of organic and inorganic aerosol: Implications for the speciation measurement of particulate matter, Atmos. Environ., 55, 229-233, https://doi.org/10.1016/j.atmosenv.2012.03.032, 2012.

Colette, A., Aas, W., Banin, L., Braban, C. F., Ferm, M., González Ortiz, A., Ilyin, I., Mar, K., Pandolfi, M., Putaud, J.-P., Shatalov, V., Solberg, S., Spindler, G., Tarasova, O., Vana, M., Adani, M., Almodovar, P., Berton, E., Bessagnet, B., Bohlin-Nizzetto, P., Boruvkova, J., Breivik, K., Briganti, G., Cappelletti, A., Cuvelier, K., Derwent, R., D’Isidoro, M., Fagerli, H., Funk, C., Garcia Vivanco, M., González Ortiz, A., Haeuber, R., Hueglin, C., Jenkins, S., Kerr, J., de Leeuw, F., Lynch, J., Manders, A., Mircea, M., Pay, M. T., Pritula, D., Putaud, J.-P., Querol, X., Raffort, V., Reiss, I., Roustan, Y., Sauvage, S., Scavo, K., Simpson, D., Smith, R. I., Tang, Y. S., Theobald, M., Tørseth, K., Tsyro, S., van Pul, A., Vidic, S., Wallasch, M., and Wind, P.: Air pollution trends in the EMEP region between 1990 and 2012, EMEP/CCC-Report 1/2016, Joint Report of the EMEP Task Force on Measurements and Modelling (TFMM), Chemical Coordinating Centre (CCC), Meteorological Synthesizing CentreEast (MSC-E), Meteorological Synthesizing Centre-West (MSCW), available at: http://hdl.handle.net/11250/2393346 (last access: 25 March 2017), 2016.

Conolly, C., Davies, M., Knight, D., Vincent, K., Sanocka, A., Lingard, J., Richie, S., Donovan, B., Collings, A., Braban, C., Tang, Y. S., Stephens, A., Twigg, M., Jones, M., Simmons, I., Coyle, C., Kentisbeer, J., Leeson, S., van Dijk, N., Nemitz, E., Langford, B., Bealey, W., Leaver, D., Poskitt, J., Carter, H., Thacker, S., Patel, M., Keenan, P., Pereira, G., Lawlor, A., Warwick, A., Farrand, P., and Sutton, M. A.: UK Eutrophying and Acidifying Atmospheric Pollutants (UKEAP) Annual Report 2015, UK Department for Environment, Food \& Rural Affairs, 2016.

Cowling, E. B., Erisman, J. W., Smeulders, S. M., Holman, S. C., and Nicholson, B. M.: Optimizing air quality management in Europe and North America: Justification for integrated management of both oxidized and reduced forms of nitrogen, Environ. Poll., 102, 599-608, https://doi.org/10.1016/S0269-7491(98)80088-2, 1998.

Dentener, F., Drevet, J., Lamarque, J. F., Bey, I., Eickhout, B., Fiore, A. M., Hauglustaine, D., Horowitz, L. W., Krol, M., Kulshrestha, U. C., Lawrence, M., Galy-Lacaux, C., Rast, S., Shindell, D., Stevenson, D., Van Noije, T., Atherton, C., Bell, N., Bergman, D., Butler, T., Cofala, J., Collins, B., Doherty, R., Ellingsen, K., Galloway, J., Gauss, M., Montanaro, V., Müller, J. F., Pitari, G., Rodriguez, J., Sanderson, M., Solmon, F., Strahan, S., Schultz, M., Sudo, K., Szopa, S., and Wild, O.: Nitrogen and sulfur deposition on regional and global scales: A multimodel evaluation, Global Biogeochem. Cy., 20, GB4003, https://doi.org/10.1029/2005GB002672, 2006.

Dore, A. J., Carslaw, D. C., Braban, C., Cain, M., Chemel, C., Conolly, C., Derwent, R. G., Griffiths, S. J., Hall, J., Hayman, G., Lawrence, S., Metcalfe, S. E., Redington, A., Simpson, D., Sutton, M. A., Sutton, P., Tang, Y. S., Vieno, 
M., Werner, M., and Whyatt, J. D.: Evaluation of the performance of different atmospheric chemical transport models and inter-comparison of nitrogen and sulphur deposition estimates for the UK, Atmos. Environ., 119, 131-143, https://doi.org/10.1016/j.atmosenv2015.08.008, 2015.

EEA: Air quality in Europe 2017, Report No 13/2017, available at: https://www.eea.europa.eu/publications/ air-quality-in-europe-2017, last access: 22 March 2017.

EMEP: EMEP Manual for Sampling and Analysis, available at: www.nilu.no/projects/ccc/manual/ (last access: 17 March 2017), 2014.

EMEP: Daily filter pack data of ammonia and ammonium (TIA) and nitric acid and nitrate (TIN) for the Eskdalemuir EMEP site, available at: http://ebas.nilu.no/, last access: 17 March 2017a.

EMEP: $\mathrm{SO}_{2}$ and $\mathrm{SO}_{4}^{2-}$ data by daily bubbler and filter pack method for the Eskdalemuir EMEP site, available at: http://ebas.nilu.no/, last access: 17 March 2017b.

EU: Directive (EU) 2016/2284 of the European Parliament and of the Council of 14 December 2016 on the reduction of national emissions of certain atmospheric pollutants, amending Directive 2003/35/EC and repealing Directive 2001/81/EC, 2016.

Evans, C. D., Monteith, D. T., Fowler, F., Cape, J. N., and Brayshaw, S.: Hydrochloric Acid: An overlooked driver of environmental change, Environ. Sci. Technol., 45, 1887-894, https://doi.org/10.1021/es103574u, 2011.

Ferm, M.: Method for determination of atmospheric ammonia, Atmos. Environ., 13, 1385-1393, https://doi.org/10.1016/00046981(79)90107-0, 1979.

Ferm, M.: A $\mathrm{Na}_{2} \mathrm{CO}_{3}$-coated denuder and filter for determination of gaseous $\mathrm{HNO}_{3}$ and particulate $\mathrm{NO}_{3}^{-}$in the atmosphere, Atmos. Environ., 20, 1193-1201, https://doi.org/10.1016/00046981(86)90153-8, 1986.

Finn, D., Rumburg, B., Claiborn, C., Bamesberger, L., and Siems, W. F.: Sampling artifacts from the use of denuder tubes with glycerol based coatings in the measurement of atmospheric particulate matter, Environ. Sci. Technol., 35, 40-44, https://doi.org/10.1021/es001325i, 2001.

Fitz, D. R.: Evaluation of Diffusion Denuder Coatings for Removing Acid Gases from Ambient Air, Final Report, U.S. Environmental Protection Agency, Riverside, 2002.

Flechard, C. R., Nemitz, E., Smith, R. I., Fowler, D., Vermeulen, A. T., Bleeker, A., Erisman, J. W., Simpson, D., Zhang, L., Tang, Y. S., and Sutton, M. A.: Dry deposition of reactive nitrogen to European ecosystems: a comparison of inferential models across the NitroEurope network, Atmos. Chem. Phys., 11, 2703-2728, https://doi.org/10.5194/acp-11-2703-2011, 2011.

Fowler, D., Sutton, M. A., Flechard, C., Cape, J. N., StoretonWest, R., Coyle, M., and Smith, R. I.: The control of $\mathrm{SO}_{2}$ dry deposition on to natural surfaces by $\mathrm{NH}_{3}$ and its effects on regional deposition, Water Air Soil Poll., 1, 39-48, https://doi.org/10.1023/A:1013161912231, 2001.

Fowler, D., Pilegaard, K., Sutton, M. A., Ambus, P., Raivonen, M., Duyzer, J., Simpson, D., Fagerli, H., Fuzzi, S., Schjoerring, J. M., Granier, C., Neftel, A., Isaksen, I. S. A., Laj, P., Maione, M., Monks, P. S., Burkhardt, J., Daemmgen, U., Neirynck, J., Personne, E., Wichink-Kruit, R., Butterbach-Bahl, K., Flechard, C., Tuovinen, J. P., Coyle, M., Gerosa, G., Loubet, B., Altimir, N., Gruenhage, L., Ammann, C., Cieslik, S., Paoletti, E., Mikkelsen, T. N., Ro-Poulsen, H., Cellier, P.,
Cape, J. N., Horváth, L., Loreto, F., Niinemets, Ü., Palmer, P. I., Rinne, J., Misztal, P., Nemitz, E., Nilsson, D., Pryor, S., Gallagher, M. W., Vesala, T., Skiba, U., Brüggemann, N., Zechmeister-Boltenstern, S., Williams, J., O'Dowd, C., Facchini, M. C., de Leeuw, G., Flossman, A., Chaumerliac, N., and Erisman, J. W.: Atmospheric composition change: EcosystemsAtmosphere interactions, Atmos. Environ., 43, 5193-5267, https://doi.org/10.1016/j.atmosenv.2009.07.068, 2009.

Gilbert, R. O.: Statistical methods for environmental pollution monitoring, New York, John Wiley \& Sons, 1987.

Gormley, P. and Kennedy, M.: Diffusion from a stream flowing through a cylindrical tube, P. Roy. Irish Acad. A, 52, 163-169, 1948.

Gregor, H.-D., Nagel, H.-D., and Posch, M.: The UN/ECE International Programme on Mapping Critical Loads and Levels, Water Air Soil Poll., 1, 5-19, https://doi.org/10.1023/a:1011503115918, 2001.

Hall, J. and Smith, R.: Trends in critical load exceedances in the UK - CEH Report to Defra, prepared under contract AQ0826, version 02/06/16, 35 pp., available at: http://www.cldm.ceh.ac. uk/sites/cldm.ceh.ac.uk/files/TrendsReport_June2015_WEB.pdf (last access: 25 January 2018), 2016.

Hallsworth, S., Dore, A. J., Bealey, W. J., Dragosits, U., Vieno, M., Hellsten, S., Tang, Y. S., and Sutton, M. A.: The role of indicator choice in quantifying the threat of atmospheric ammonia to the "Natura 2000" network, Environ. Sci. Policy, 13, 671-687, https://doi.org/10.1016/j.envsci.2010.09.010, 2010.

Hayman, G., Vincent, K. J., Lawrence, H., Smith, M., Davies, M., Sutton, M., Tang, Y. S., Dragosits, U., Love, L., Fowler, D., Kendall, M., and Page, H.: Management and Operation of the UK Acid Deposition Monitoring Network: Data Summary for 2004, Department for Environment, Food and Rural Affairs, the Scottish Executive, the Welsh Assembly Government, Department of the Environment Northern Ireland, AEAT/ENV/R/2093 Issue 1, AEA Technology plc, The Gemini Building, Fermi Avenue, Harwell, 2005.

Hayman, G., Lawrence, H., Vincent, K., Smith, M., Davies, M., Colbeck, C., Hasler, S., Baker, S., Stedman, J., Sansom, L., Page, H., and Kendall, M.: Rural Sulphur Dioxide Monitoring in the UK: Data Summary 2001-2005, Report ref: ED48204, AEAT/ENV/R/2292 Issue 1, 2006.

Hayman, G. D., Vincent, K., Lawrence, H., Smith, M., Colbeck, C., Davies, M., Sutton, M. A., Tang, Y. S., Dragosits, U., Love, L., Fowler, D., Kendall, M., and Page, H.: Management and Operation of the UK Acid Deposition Monitoring Network: Data Summary for 2005, AEA Energy \& Environment Report AEAT/ENV/R/2342 Issue 1, AEA Technology plc, The Gemini Building, Fermi Avenue, Harwell, 2007.

Horvath, L., Fagerli, H., and Sutton, M. A.: Long-Term Record (1981-2005) of Ammonia and Ammonium Concentrations at K-Puszta Hungary and the Effect of Sulphur Dioxide Emission Change on Measured and Modelled Concentrations, Atmospheric Ammonia, edited by: Sutton, M. A., Reis, S., and Baker, S. M. H., Springer, Heidelberg Germany, 181-185, 2009.

Ianniello, A., Spataro, F., Esposito, G., Allegrini, I., Hu, M., and Zhu, T.: Chemical characteristics of inorganic ammonium salts in $\mathrm{PM}_{2.5}$ in the atmosphere of Beijing (China), Atmos. Chem. Phys., 11, 10803-10822, https://doi.org/10.5194/acp-11-108032011, 2011. 
Jones, A. M. and Harrison, R. M.: Temporal trends in sulphate concentrations at European sites and relationships to sulphur dioxide, Atmos. Environ., 45, 873-882, https://doi.org/10.1016/j.atmosenv.2010.11.020, 2011.

Keene, W. C., Pszenny, A. A. P., Galloway, J. N., and Hawley, M. E.: Sea salt corrections and interpretation of constitutent ratios in marine precipitation, J. Geophys. Res., 91, 6647-6658, https://doi.org/10.1029/JD091iD06p06647, 1986.

Kitto, A.-M. N. and Harrison, R. M.: Nitrous and nitric acid measurements at sites in South-East England, Atmos. Environ., 26, 235-241, https://doi.org/10.1016/0960-1686(92)90305-5, 1992.

Marchetto, A., Rogora, M., and Arisci, S.: Trend analysis of atmospheric deposition data: A comparison of statistical approaches, Atmos. Environ., 64, 95-102, https://doi.org/10.1016/j.atmosenv.2012.08.020, 2013.

Meals, D. W., Spooner, J., Dressing, S. A., and Harcum, J. B.: Statistical analysis for monotonic trends, TechNotes 6, National Nonpoint Source Monitoring Program, U.S. Environmental Protection Agency, 23 pp., available at: https://www.epa.gov/sites/production/files/2016-05/documents/ tech_notes_6_dec2013_trend.pdf (last access: 20 March 2017), 2011.

McLeod, A. I.: Package "Kendall", version 2.2, Kendall rank correlation and Mann-Kendall trend test, available at: https://cran. r-project.org/web/packages/Kendall/Kendall.pdf (last access: 17 February 2017), 2015.

Mihalopoulos, N., Kerminen, V. M., Kanakidou, M., Berresheim, H., and Sciare, J.: Formation of particulate sulfur species (sulfate and methanesulfonate) during summer over the Eastern Mediterranean: A modelling approach, Atmos. Environ., 41, 6860-6871, https://doi.org/10.1016/j.atmosenv.2007.04.039, 2007.

Monteith, D., Henrys, P., Banin, L., Smith, R., Morecroft, M., Scott, T., Andrews, C., Beaumont, D., Benham, S., Bowmaker, V., Corbett, S., Dick, J., Dodd, B., Dodd, N., McKenna, C., McMillan, S., Pallett, D., Pereira, M. G., Poskitt, J., Rennie, S., Rose, R., Schäfer, S., Sherrin, L., Tang, S., Turner, A., and Watson, H.: Trends and variability in weather and atmospheric deposition at UK Environmental Change Network sites (1993-2012), Ecol. Indic., 68, 21-35, https://doi.org/10.1016/j.ecolind.2016.01.061, 2016

NAEI: UK emissions data selector, National Atmospheric Emissions Inventory, available at: http://naei.beis.gov.uk/data/ data-selector-results?q=101505)?, last access: 19 September 2018

O'Dowd, C. D. and de Leeuw, G.: Marine aerosol production: a review of the current knowledge, Phil. Trans. R. Soc. A, 365, 1753-1774, https://doi.org/10.1098/rsta.2007.2043, 2007.

Perrino, C., De Santis, F., and Febo, A.: Criteria for the choice of a denuder sampling technique devoted to the measurement of atmospheric nirous and nitric acids, Atmos. Environ., 24, 617-626, https://doi.org/10.1016/0960-1686(90)90017-H, 1990.

Pio, C.: Measurement of ammonia an ammonium in the atmosphere by denuder and filter pack methods, Evaluation of the Rome Field Intercomparison Exercise, Development of Analytical Techniques for Atmospheric Pollutants, Air Pollution Research Report, 41, 239-252, 1992.

Pohlert, T.: Package "Trend", version 0.2.0: Non-Parametric Trend Tests and Change-Point Detection, available at: https://cran. r-project.org/web/packages/trend/trend.pdf (last access: 10 October 2018), 2016.

Pope, R. J., Butt, E. W., Chipperfield, M. P., Doherty, R. M., Fenech, S., Schmidt, A., Arnold, S. R., and Savage, N. H.: The impact of synoptic weather on UK surface ozone and implications for premature mortality, Environ. Res. Lett., 11, 124004 , https://doi.org/10.1088/1748-9326/11/12/124004, 2016.

Possanzini, M., Febo, A., and Liberti, A.: New design of a highperformance denuder for the sampling of atmospheric pollutants, Atmos. Environ., 17, 2605-2610, https://doi.org/10.1016/00046981(83)90089-6, 1983.

Putaud, J. P., Van Dingenen, R., Alastuey, A., Bauer, H., Birmili, W., Cyrys, J., Flentje, H., Fuzzi, S., Gehrig, R., Hansson, H. C., and Harrison, R. M.: A European aerosol phenomenology-3: Physical and chemical characteristics of particulate matter from 60 rural, urban, and kerbside sites across Europe, Atmos. Environ., 44, 1308-1320, https://doi.org/10.1016/j.atmosenv.2009.12.011, 2010.

ROTAP: Review of Transboundary Air Pollution: Acidification, Eutrophication, Ground Level Ozone and Heavy Metals in the UK, Contract Report to the Department for Environment, Food and Rural Affairs, Centre for Ecology \& Hydrology, available at: http://www.rotap.ceh.ac.uk/ (last access: 30 March 2018), 2012.

Roth, B. and Okada, K.: On the modification of sea-salt particles in the coastal atmosphere, Atmos. Environ., 32, 1555-1569, 1998.

Rumsey, I. C. and Walker, J. T.: Application of an online ionchromatography-based instrument for gradient flux measurements of speciated nitrogen and sulfur, Atmos. Meas. Tech., 9, 2581-2592, https://doi.org/10.5194/amt-9-2581-2016, 2016.

Schmitt, A.-D. and Stille, P.: The source of calcium in wet atmospheric deposits: Ca-Sr isotope evidence, Geochim. Cosmochim. Ac., 69, 3463-3468, https://doi.org/10.1016/j.gca.2004.11.010, 2005.

Schrader, F., Schaap, M., Zöll, U., Kranenburg, R., and Brümmer, C.: The hidden cost of using low resolution concentration data in the estimation of $\mathrm{NH}_{3}$ dry deposition fluxes, Sci. Rep., 8, 969, https://doi.org/10.1038/s41598-017-18021-6, 2018.

Sickles, I. J. E., Hodson, L. L., and Vorburger, L. M.: Evaluation of the filter pack for long-duration sampling of ambient air, Atmos. Environ., 33, 2187-2202, https://doi.org/10.1016/S13522310(98)00425-7, 1999.

Smith, R. I., Fowler, D., Sutton, M. A., Flechard, C., and Coyle, M.: Regional estimation of pollutant gas dry deposition in the UK: model description, sensitivity analyses and outputs, Atmos. Environ., 34, 3757-3777, https://doi.org/10.1016/s13522310(99)00517-8, 2000.

Steinle, S.: Report on work placement at the Centre for Ecology and Hydrology (CEH), Edinburgh, 01/09/2008-28/02/2009, 2009.

Stelson, A. W. and Seinfeld, J. H.: Relative humidity and temperature dependence of the ammonium nitrate dissociation constant, Atmos. Environ., 16, 983-992, https://doi.org/10.1016/00046981(82)90184-6, 1982.

Sutton, M. A., Tang, Y. S., Dragosits, U., Fournier, N., Dore, A. J., Smith, R. I., Weston, K. J., and Fowler, D.: A spatial analysis of atmospheric ammonia and ammonium in the UK, Sci. World J., 28, 275-286, https://doi.org/10.1100/tsw.2001.313, 2001a.

Sutton, M. A., Tang, Y. S., Miners, B., and Fowler, D.: A new diffusion denuder system for long-term, regional monitoring of atmo- 
spheric ammonia and ammonium, Water Air Soil Poll., 1, 145156, https://doi.org/10.1023/A:1013138601753, 2001b.

Sutton, M. A., Nemitz, E., Erisman, J. W., Beier, C., Bahl, K. B., Cellier, P., de Vries, W., Cotrufo, F., Skiba, U., Di Marco, C., Jones, S., Laville, P., Soussana, J. F., Loubet, B., Twigg, M., Famulari, D., Whitehead, J., Gallagher, M. W., Neftel, A., Flechard, C. R., Herrmann, B., Calanca, P. L., Schjoerring, J. K., Daemmgen, U., Horvath, L., Tang, Y. S., Emmett, B. A., Tietema, A., Penuelas, J., Kesik, M., Brueggemann, N., Pilegaard, K., Vesala, T., Campbell, C. L., Olesen, J. E., Dragosits, U., Theobald, M. R., Levy, P., Mobbs, D. C., Milne, R., Viovy, N., Vuichard, N., Smith, J. U., Smith, P., Bergamaschi, P., Fowler, D., and Reis, S.: Challenges in quantifying biosphere-atmosphere exchange of nitrogen species, Environ. Poll., 150, 125-139, https://doi.org/10.1016/j.envpol.2007.04.014, 2007.

Sutton, M. A., Oenema, O., Erisman, J. W., Leip, A., van Grinsven, H., and Winiwarter. W.: Too much of a good thing, Nature, 472, 159-161, https://doi.org/10.1038/472159a, 2011.

Tang, Y. S. and Sutton, M. A.: Quality management in the UK national ammonia monitoring network, in: Proceedings of the International Conference: QA/QC in the field of emission and air quality measurements: harmonization, standardization and accreditation, Prague, 21-23 May 2003, edited by: Borowiak, A., Hafkenscheid, T., Saunders, A., and Woods, P., European Commission, Ispra, Italy, 297-307, 2003.

Tang, Y. S., Simmons, I., van Dijk, N., Di Marco, C., Nemitz, E., Dammgen, U., Gilke, K., Djuricic, V., Vidic, S., Gliha, Z., Borovecki, D., Mitosinkova, M., Hanssen, J. E., Uggerud, T. H., Sanz, M. J., Sanz, P., Chorda, J. V., Flechard, C. R., Fauvel, Y., Ferm, M., Perrino, C., and Sutton, M. A.: European scale application of atmospheric reactive nitrogen measurements in a low-cost approach to infer dry deposition fluxes, Agr. Ecosyst. Environ., 133, 183-195, https://doi.org/10.1016/j.agee.2009.04.027, 2009.

Tang, Y. S., Cape, J. N., Braban, C. F., Twigg, M. M., Poskitt, J., Jones, M. R., Rowland, P., Bentley, P., Hockenhull, K., Woods, C., Leaver, D., Simmons, I., van Dijk, N., Nemitz, E., and Sutton, M. A.: Development of a new model DELTA sampler and assessment of potential sampling artefacts in the UKEAP AGANet DELTA system: summary and technical report, London, Defra, CEH Project no. C04544, C04845, available at: https://uk-air. defra.gov.uk/library/reports?report_id=861 (last access: 20 October 2018), 2015.

Tang, Y. S., Braban, C. F., Dragosits, U., Dore, A. J., Simmons, I., van Dijk, N., Poskitt, J., Dos Santos Pereira, G., Keenan, P. O., Conolly, C., Vincent, K., Smith, R. I., Heal, M. R., and Sutton, M. A.: Drivers for spatial, temporal and long-term trends in atmospheric ammonia and ammonium in the UK, Atmos. Chem. Phys., 18, 705-733, https://doi.org/10.5194/acp-18-7052018, 2018

Tang, Y. S., Poskitt, J., Cape, J. N., Nemitz, E., Bealey,W. J., Leaver, D., Beith, S., Thacker, S., Simmons, I., Letho, K., Wood, C., Pereira, G., Sutton, M. A., Davies, M., Conolly, C., Donovan, B., and Braban, C. F.: UK Eutrophying and Acidifying Atmospheric Pollutant project's Acid Gas and Aerosol Network (Data funded by Defra and the Devolved Administrations and published under the Open Government Licence v1.0, AGANet, available at: http://uk-air.defra.gov.uk/networks/network-info?view= ukeap, last access: 23 March 2017a.
Tang, Y. S., Poskitt, J., Cape, J. N., Nemitz, E., Bealey,W. J., Leaver, D., Simmons, I., Wood, C., Pereira, G., Sutton, M. A., Davies, M., Conolly, C., Donovan, B., and Braban, C. F.: UK Eutrophying and Acidifying Atmospheric Pollutant project's National Ammonia Monitoring Network (Data funded by Defra and the Devolved Administrations and published under the Open Government Licence v1.0), NAMN, available at: https://uk-air.defra gov.uk/networks/network-info?view=nh3, last access: 23 March $2017 b$.

Tørseth, K., Aas, W., Breivik, K., Fjæraa, A. M., Fiebig, M., Hjellbrekke, A. G., Lund Myhre, C., Solberg, S., and Yttri, K. E.: Introduction to the European Monitoring and Evaluation Programme (EMEP) and observed atmospheric composition change during 1972-2009, Atmos. Chem. Phys., 12, 5447-5481, https://doi.org/10.5194/acp-12-5447-2012, 2012.

Twigg, M. M., Ilyinskaya, E., Beccaceci, S., Green, D. C., Jones, M. R., Langford, B., Leeson, S. R., Lingard, J. J. N., Pereira, G. M., Carter, H., Poskitt, J., Richter, A., Ritchie, S., Simmons, I., Smith, R. I., Tang, Y. S., Van Dijk, N., Vincent, K., Nemitz, E., Vieno, M., and Braban, C. F.: Impacts of the 2014 2015 Holuhraun eruption on the UK atmosphere, Atmos. Chem. Phys., 16, 11415-11431, https://doi.org/10.5194/acp-16-114152016, 2016.

UNECE: Protocol to Abate Acidification, Eutrophication and Ground-level Ozone, the 1999 Gothenburg Protocol to Abate Acidification, Eutrophication and Ground-level Ozone, available at: http://www.unece.org/env/lrtap/multi_h1.html, last access: March 2018.

Vieno, M., Heal, M. R., Hallsworth, S., Famulari, D., Doherty, R. M., Dore, A. J., Tang, Y. S., Braban, C. F., Leaver, D., Sutton, M. A., and Reis, S.: The role of long-range transport and domestic emissions in determining atmospheric secondary inorganic particle concentrations across the UK, Atmos. Chem. Phys., 14, 8435-8447, https://doi.org/10.5194/acp-14-8435-2014, 2014.

Vieno, M., Heal, M. R., Twigg, M. M., MacKenzie, I. A., Braban, C. F., Lingard, J. N. N., Ritchie, S., Beck, R. C., Móring, A., Ots, R., Di Marco, C. F., Nemitz, E., Sutton M. A., and Reis, S.: The UK particulate matter air pollution episode of March-April 2014: more than Saharan dust, Environ. Res. Lett., 11, 044004, https://doi.org/10.1088/1748-9326/11/4/044004, 2016.

Werner, M., Kryza, M., Dore, A. J., Blas, M., Hallsworth, S., Vieno, M., Tang, Y. S., and Smith, R. I.: Modelling of marine base cation emissions, concentrations and deposition in the UK, Atmos. Chem. Phys., 11, 1023-1037, https://doi.org/10.5194/acp11-1023-2011, 2011. 